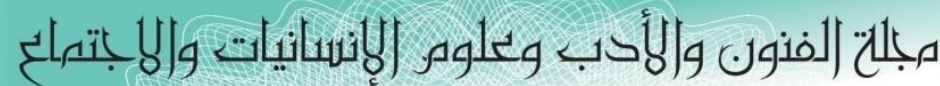

Journal of Arts, Literature, Humanities and Social Sciences

ISSN online: 2414 - 3383

ISSN print: 2616 - 3810

العدد (42) ايلول - سبتهبر 2019

LALLHSS

Www.jalhss.com

\title{
استخدام الابناء شبكات التواصل الاجتماعي وانعكاسها على انماط الحوار الاسري الاجئمي
}

د.أسماء محمد اسماعيل الأنصاري

استاذ مساعد بكلية التربية الاساسية - قسم الاقتصاد المنزلي

الكويت

الملخص

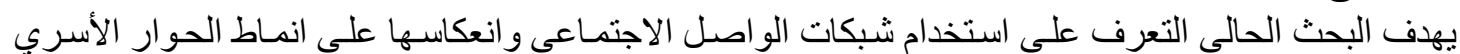

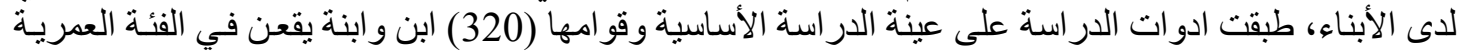

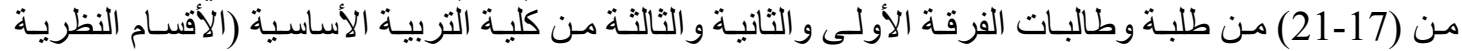

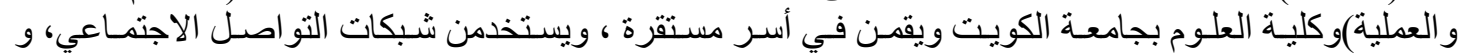

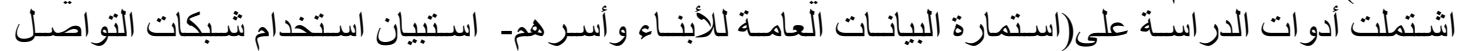

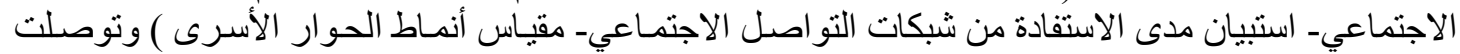

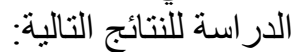
1- - أن أكثر دو افع استخدام شبكات التو اصل الاجتماعي لأفر اد عينة البحث كان اكتسـاب مهار ات وخبرات جديدة بنسبة 8.3

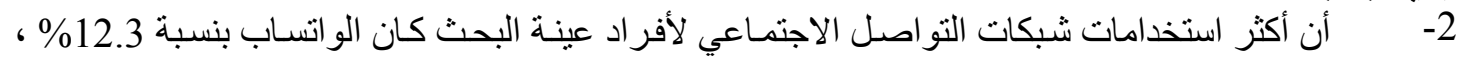

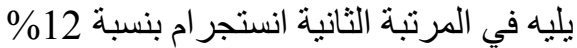
3- - أن أكثر أنماط الحوار الأسري لأفر اد عينة البحث كان أنماط الحوار الإيجابية بنسبة 53.2\%

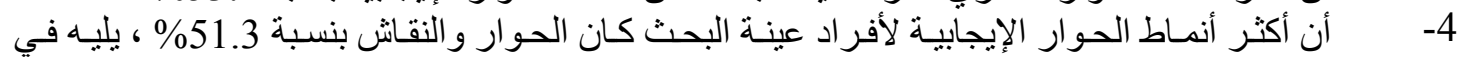

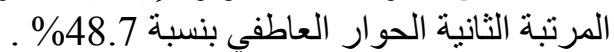
5- أن أكثر أنماط الحوار السلبية لأفر اد عينة البحث كان الحوار التسلطي بنسبة 52.3\% ، يليه في المرتبة الثانية الحوار العدو اني بنسبة 47.7 \%

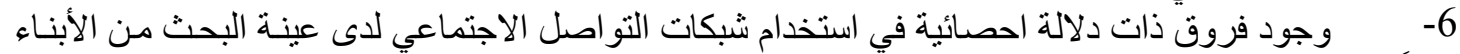

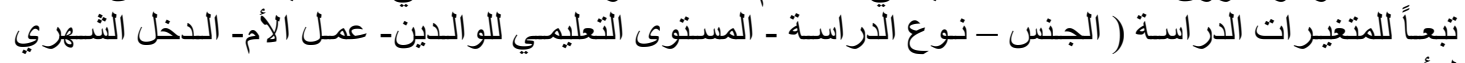
7 الاسرة)

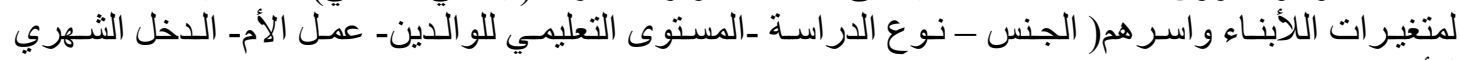
لمألأسرة) 8- وجود علاقة ارتباطية بين مدى الاستفادة من استخدام شبكات التو اصل الاجتمـاعي و انماط الحوار

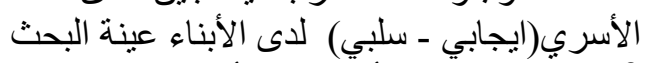

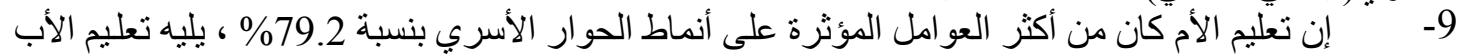

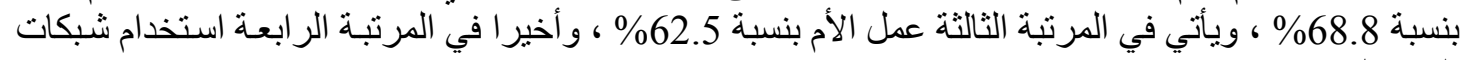

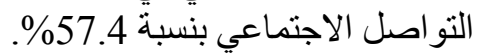

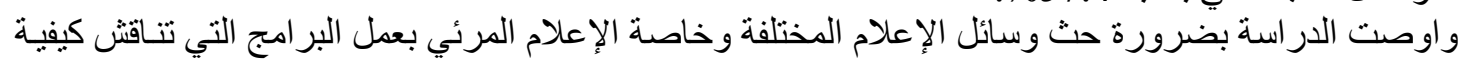

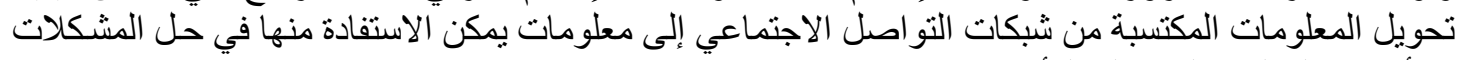
والأزمات الحالية و المستقبلية للأبناء. 


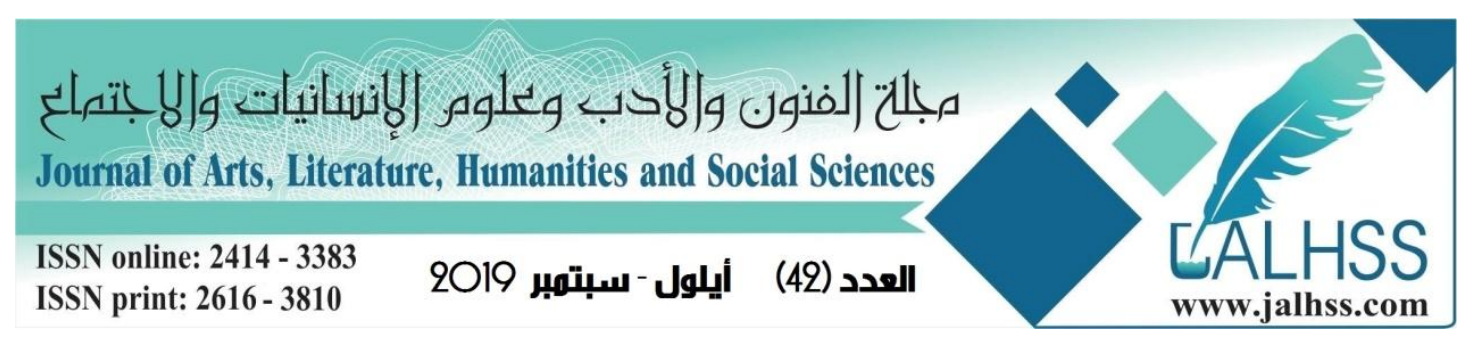

\title{
The Use of Social Networking Networks and Their Reflection on Patterns of Family Dialogue
}

\begin{abstract}
The present study aims at identifying the use of social connection networks and their reflection on the patterns of family dialogue among children. The study tools were applied to the basic study sample of 320 boys and girls in the age group (17-21) of the first, second and third students of the Faculty of Education (The theoretical and practical sections) and the Faculty of Science at Kuwait University are in stable families and use social networks. The study tools included (the general data form for the children and their families - the social networks questionnaire - the questionnaire on the use of social networks - Measuring patterns of prisoners dialogue) and the study found the following results:

1 - The most motivated use of social networks of members of the research sample was to acquire new skills and experience by $8.3 \%$

2 - The most uses of social networks of members of the research sample was whatsapp massenger $12.3 \%$, followed by the second Instagramby $12 \%$

3 - The most common patterns of family dialogue of the sample of the research sample was positive dialogue patterns by $53.2 \%$

4 - The most positive types of dialogue for the members of the research sample was dialogue and discussion by $51.3 \%$, followed by emotional dialogue at the rate of $48.7 \%$.

5 - The most negative types of dialogue for the members of the sample of the research was the authoritarian dialogue by $52.3 \%$, followed by the second in the dialogue of aggression by $47.7 \%$.

6- There are statistically significant differences in the use of social networks in the sample of children according to the variables of study (sex - type of study - parents' educational level - mother's work - monthly income of the family)

7 - There are statistically significant differences in the patterns of family dialogue (positive - negative) in the research sample according to the variables of children and their families (sex - type of study - parental level of education - mother's work monthly income of the family)

8 - the existence of a relationship between the use of the use of social networks and patterns of family dialogue (positive - negative) in the sons of the research sample

9. Mother's education was the most influential factor in the patterns of family dialogue, with $79.2 \%$, followed by father's education at $68.8 \%$. The mother's work ranked third with $62.5 \%$. Finally, the social networks accounted for $57.4 \%$.

The study recommended the necessity of urging the various media, especially the visual media, to work on programs that discuss how to transform information gained from social networks into information that can be used to solve the current and future problems and crises
\end{abstract}




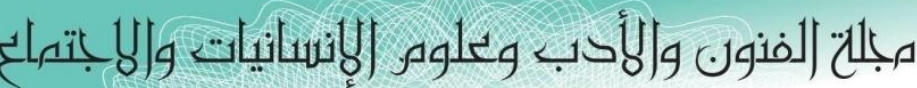

Journal of Arts, Literature, Humanities and Social Sciences

ISSN online: 2414 - 3383

ISSN print: 2616 - 3810

\section{العدد (42) أيلول -سبتمبر 2019}

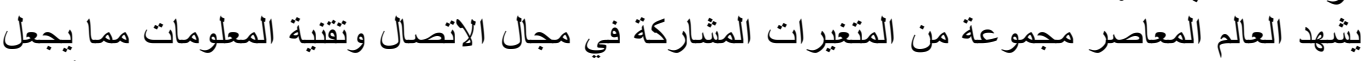

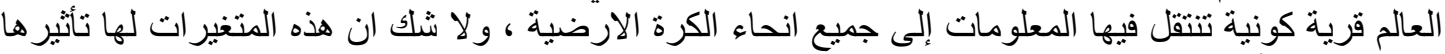

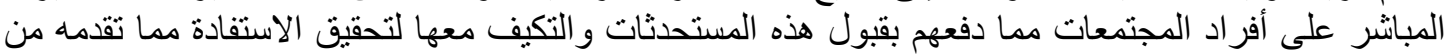

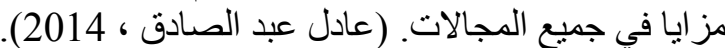

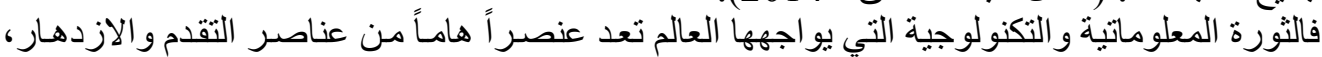

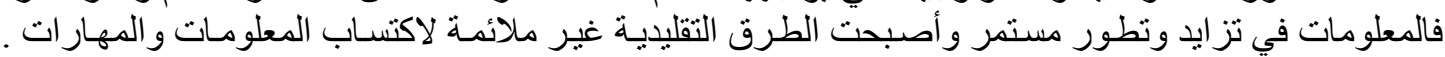

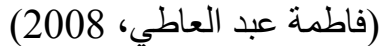

وقد أصبحت شبكات المعلومات تستخدم في شنى مناحي الحياة اليوميـة فهي لهات تأثنير على حياة الفرد

حيث تؤثر على سلوكياته و اتجاهاته وتفاعلاته المجتمعية. (Dwyer.ton, 2002)

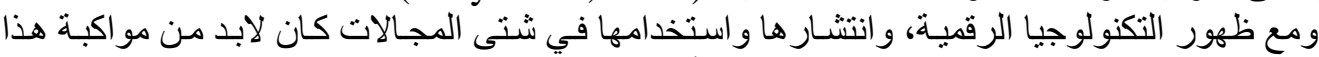

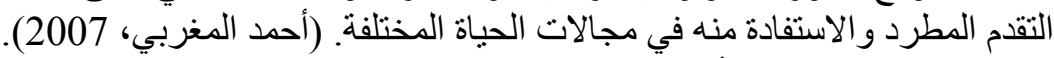

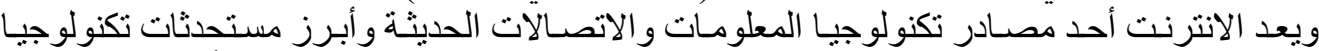

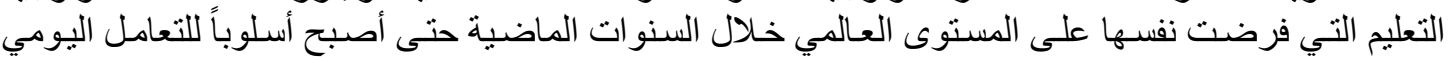

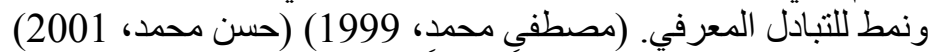

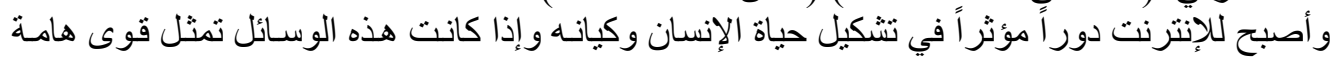

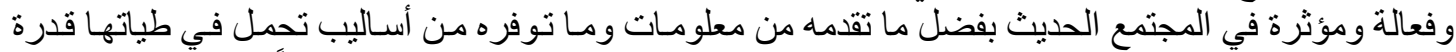

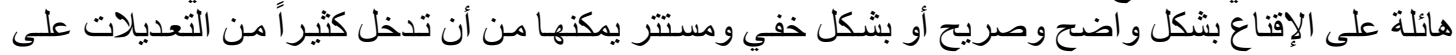

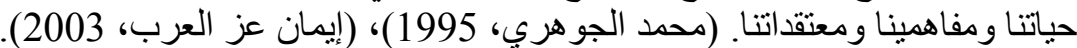

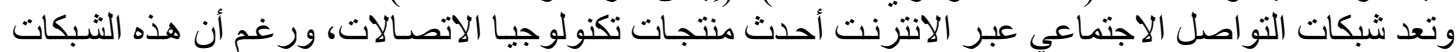

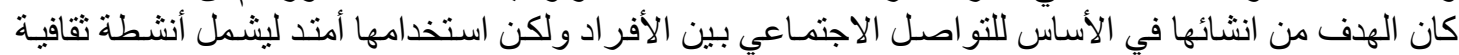

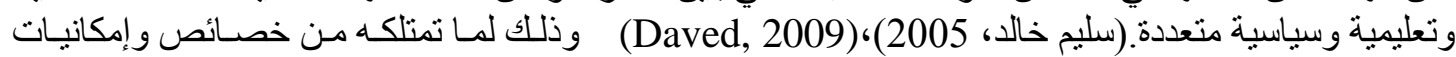

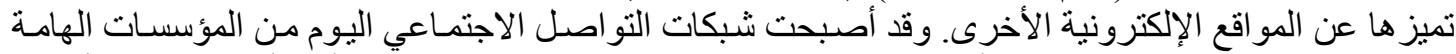

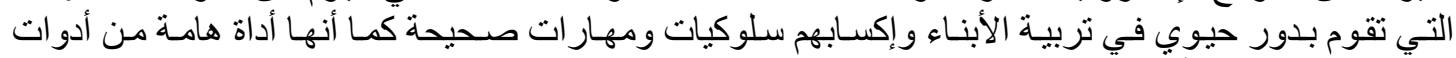

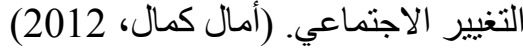

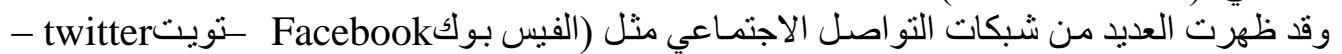

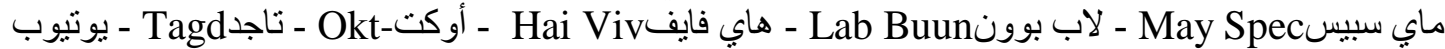
YouTube

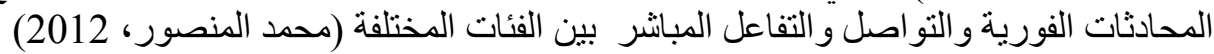

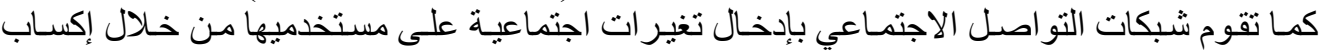

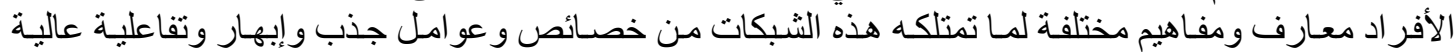

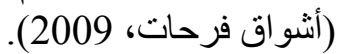

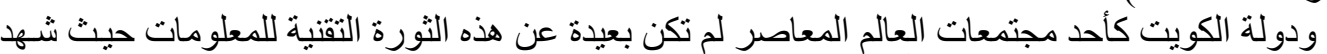

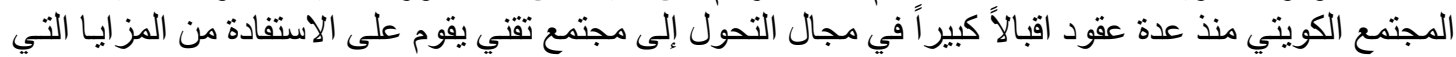

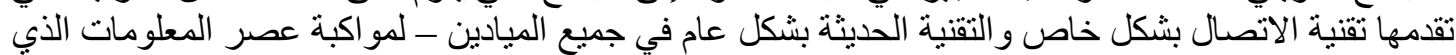

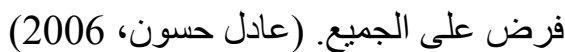
وتثنير الإحصائيات في دولة الكويت إلى ارتفاع نسبة مستخدمي الانترنت في دولة الكويت حيث الإني أظهر

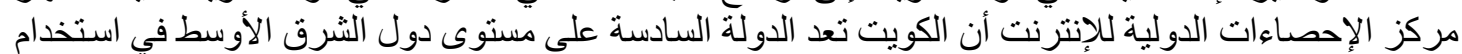

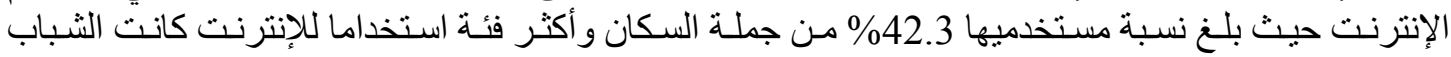

و المر اهقين وبنسبة 67\% من إجمالي مستخدمي هذه الثبكة. (Internet World State, 2017)

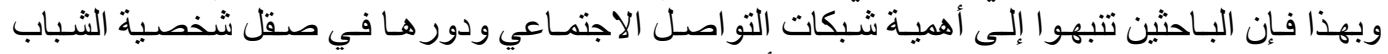

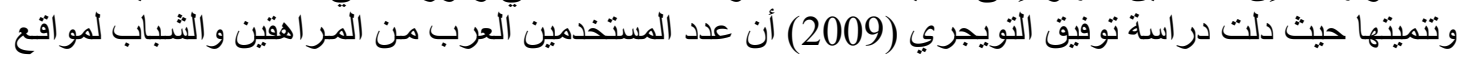




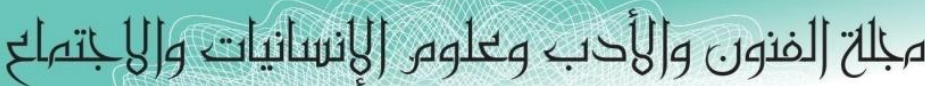

Journal of Arts, Literature, Humanities and Social Sciences

ISSN online: 2414 - 3383

ISSN print: 2616 - 3810

\section{العدد (42) أيلول -سبتمبر 2019}

التو اصل الاجتماعي يصل إلى (15) مليون شخص.

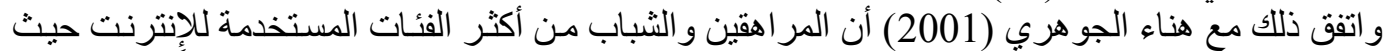

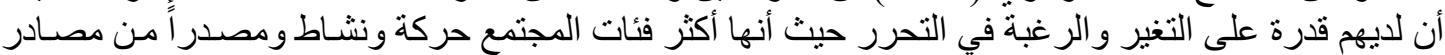

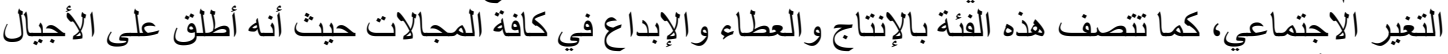

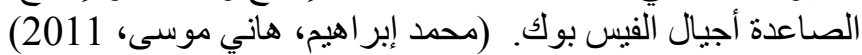

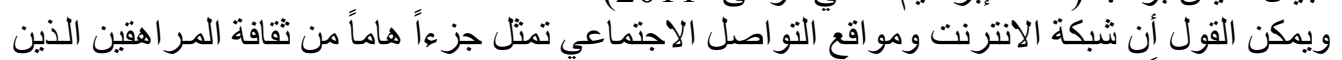

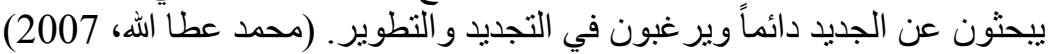

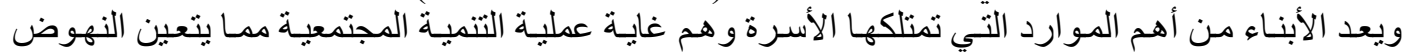

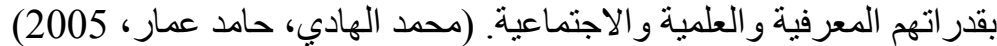

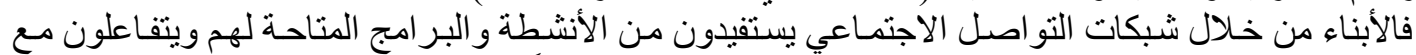

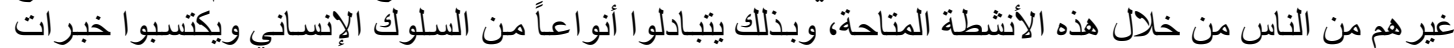

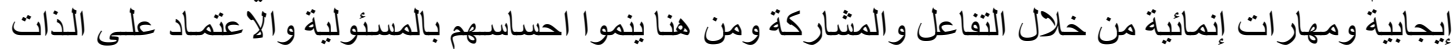

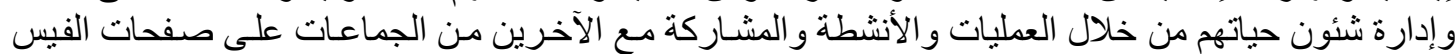
بوك. (عماد إبر اهيم، 2009) (صلاح من عمار العمان 2010).

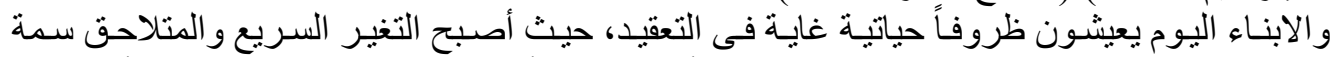

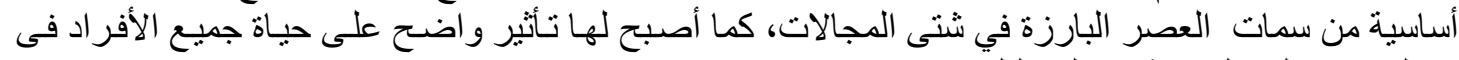

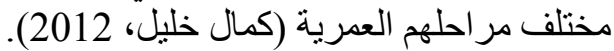

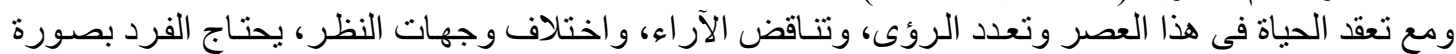

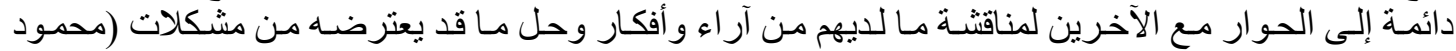

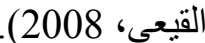

لذلك يعد الحوار من الأمور الضرورية فى الحياة فأغلب أنشطة حياتنا وما ينجم عنها من خلافات فئات قد أصبح

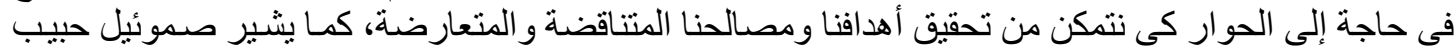

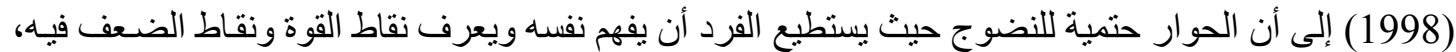

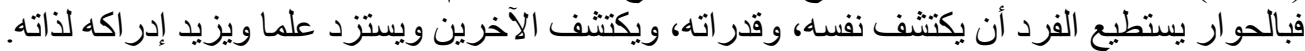

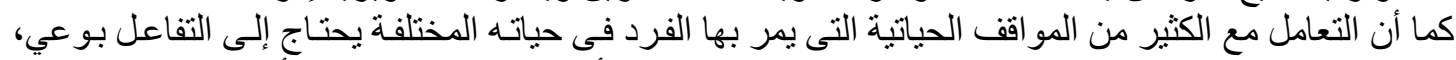

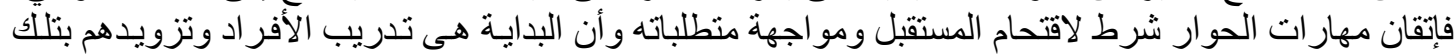

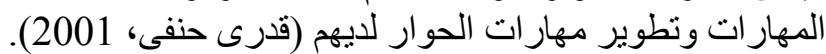

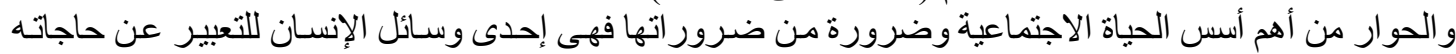

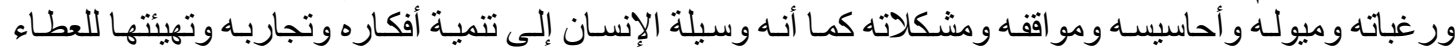
و الإبداع و المشاركة فى تحقيق حياة متحضرة إذ من خلال الحوار يتم الو اصل مـع الآخرين و التفاعل معهم (منى اللبودي، 2000).

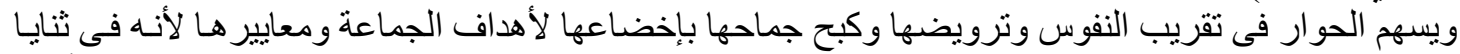

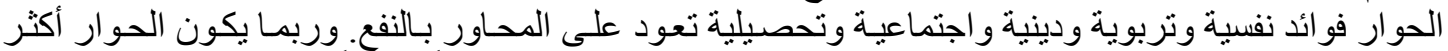

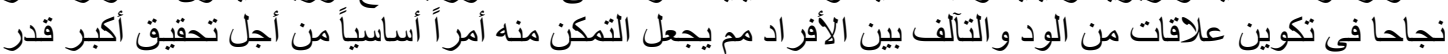

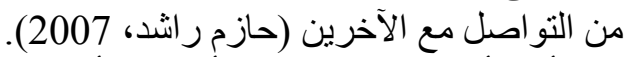

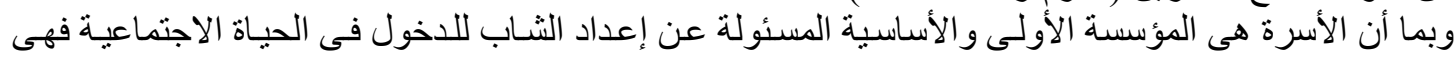

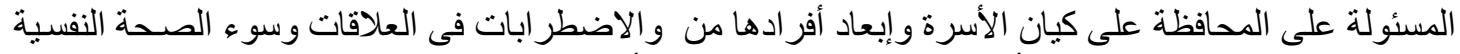

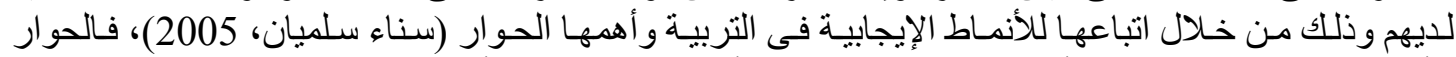
الأسرى الإيجابي يوثق بناء الأسرة ويقوى التماسك بين أعضائها ويصل بالأبناء إلى مرحلة التكامل والئل والاستقلال

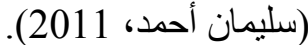
وذللك باعنبار أن الأجو اء الفكرية و النفسية و العاطفية التى تخلقها الأسرة للأبناء تمنحه القدرة على التكيف الجدى مع (B) نفسه ومع أسرته و مجتمعه (Bela \& Patrick, 2005). 


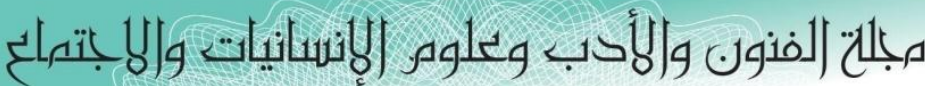

Journal of Arts, Literature, Humanities and Social Sciences

ISSN online: 2414 - 3383

ISSN print: 2616 - 3810

\section{العدد (42) أيلول - سبتمبر 2019}

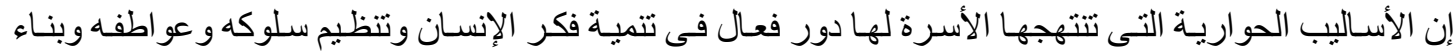

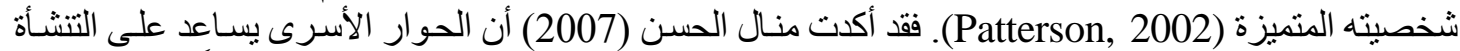

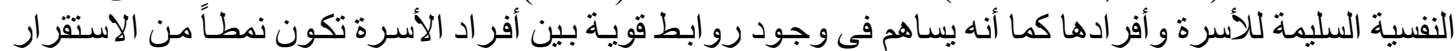
الذى يظهر فى تصرفات أعضائها.

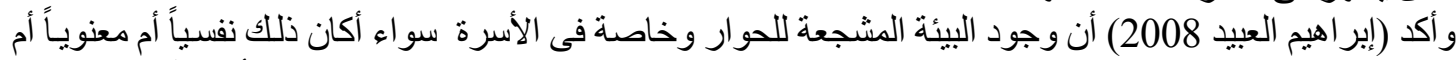

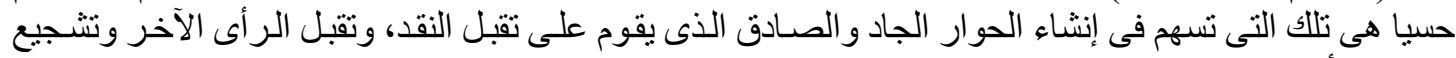

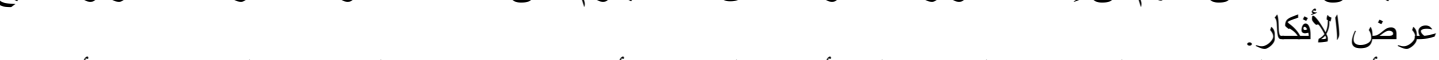

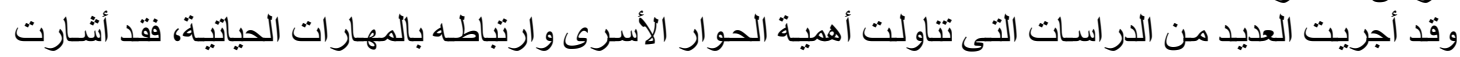
(Patterson, 2002) و والذى يقود فى النهاية إلى النجاح و الإنجار.

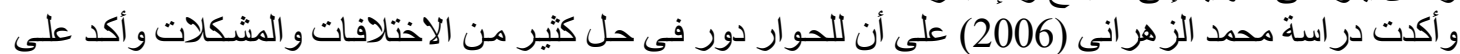

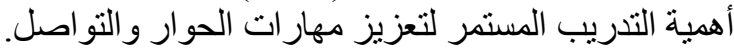
بينما أثارت دراسة (Jeffrey, 2007) إلى أن الأسرة قد تلتبع أنماطاً من الحوار السلبية التى قد تهدد كيان الأسرة وتؤثر على الحالة النفسية لأبنائها.

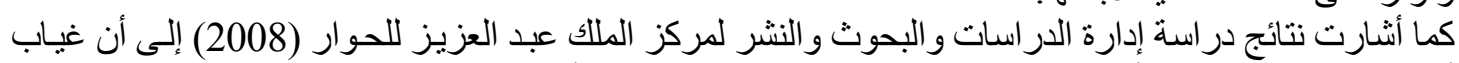

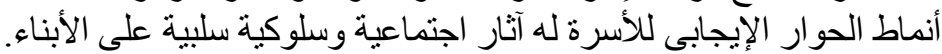

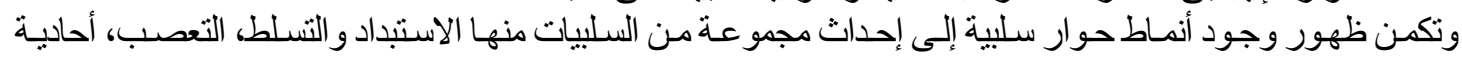
التفكير، العنف، اللامبالاة (منى اللبودي، 2003)، (إبر اهيم العبيد، 2008).

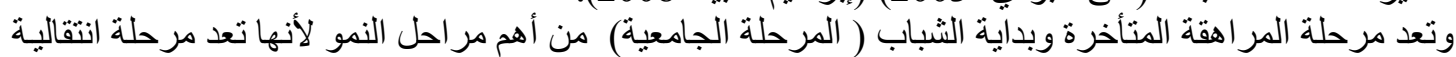

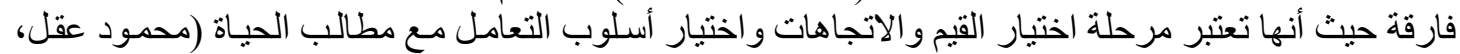

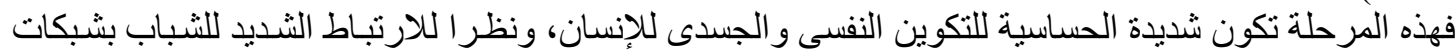

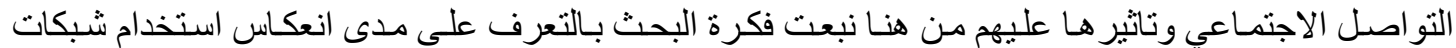

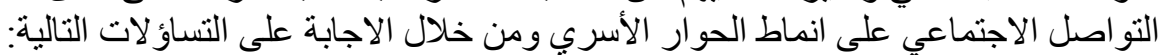

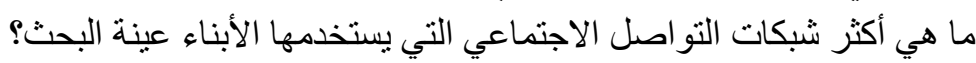

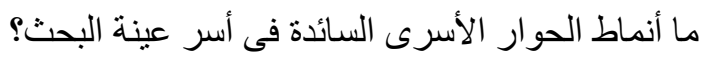

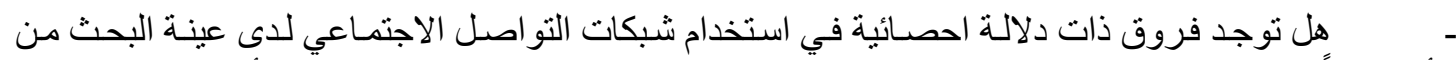

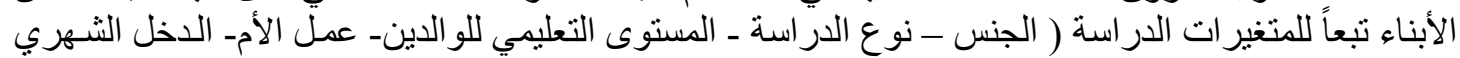

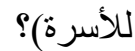
- هل هنالك فروق فى أنماط الحوار الأسرى لاى عينة البحث تبعاً لمتغيرات اللأبناء و اسر هم (الجنس -

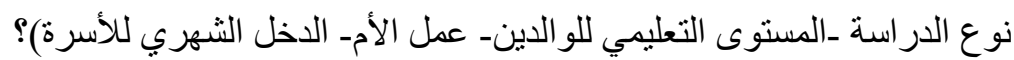

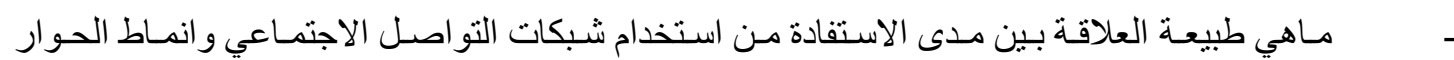
الأسري لاى الأبناء عينة البحث؟ العيدة

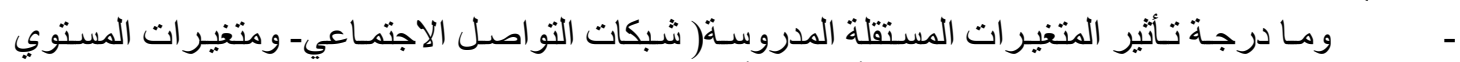
الاجتماعي والاقتصادي) على انماط الحوار الأسري للأبناء؟

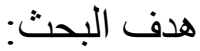
يهذف البحث الحالى التعرف على استخدام شبكات التو اصل الاجتماعي و انعكاسها على انماط الحوار الأسري

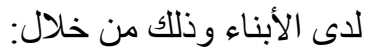
1- - الحديد أكثر شبكات التو اصل الاجتماعي التي يستخدمها الأبناء عينة البحث 2- الكثف عن أنماط الحوار الأسرى السائدة في أسر عينة البحث 
مبلحت (لفنون والأدب وتلوه الإنسانيات والبانتهاع

Journal of Arts, Literature, Humanities and Social Sciences

ISSN online: 2414 - 3383

ISSN print: 2616 - 3810

\section{العدد (42) ايلول - سبتمبر 2019}

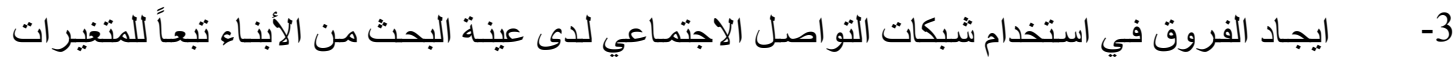

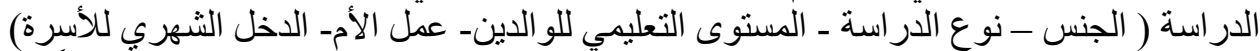

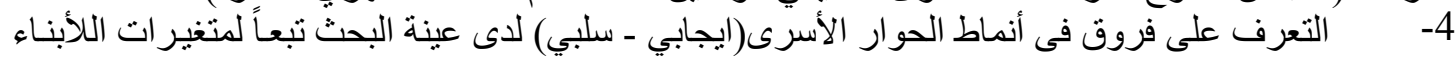

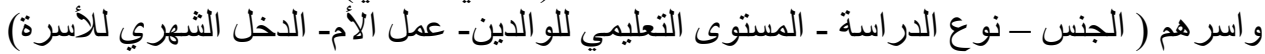

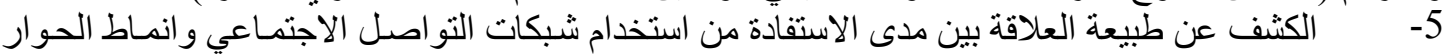
الأسري (ايجابي - سلبي) لدى الأبناء عينة البحثب

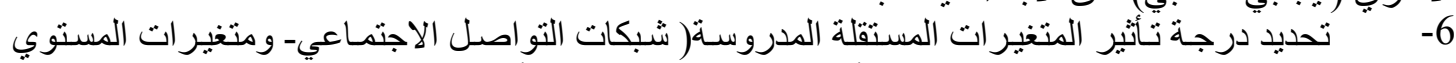
الاجتماعي والاقتصادي) على انماط الحوار الأسري(ايجابي ـ سلبي) للأبناء

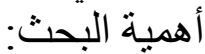

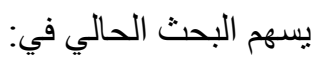

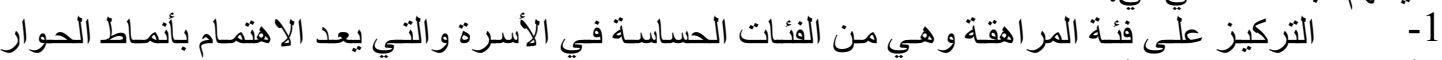

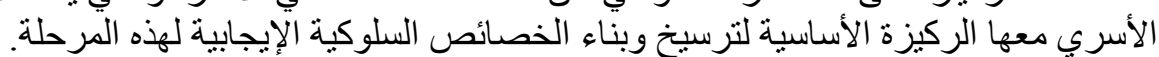

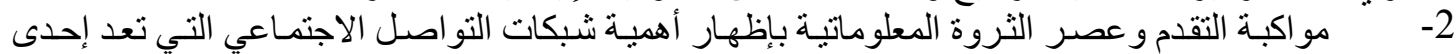

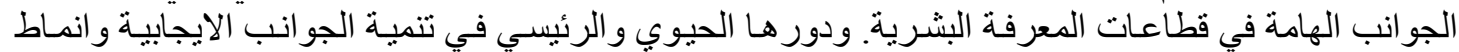
الحوار الايجابية لدى الأبناء.

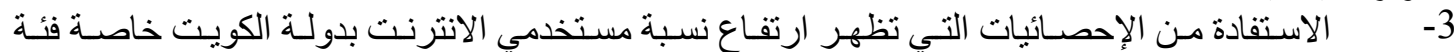

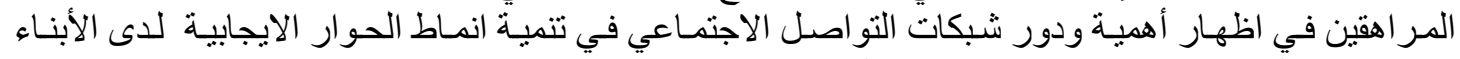

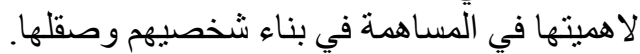

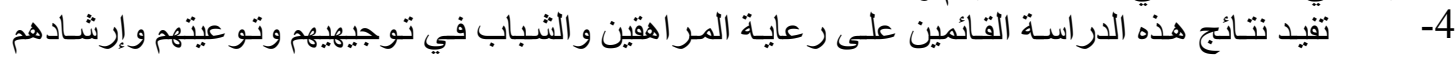

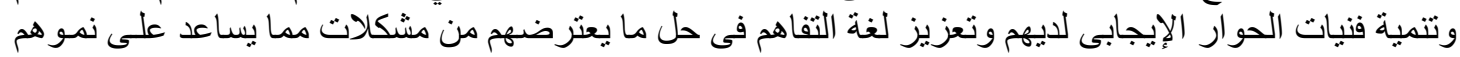
النفسى السليم وبناء جو انب شخصيات الإبهم.

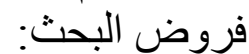

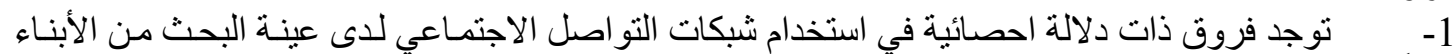

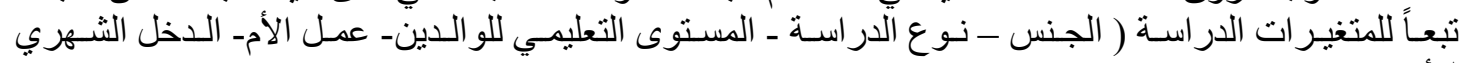

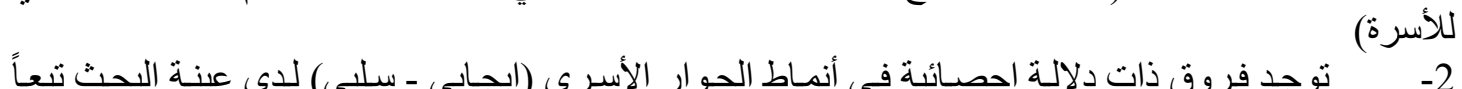

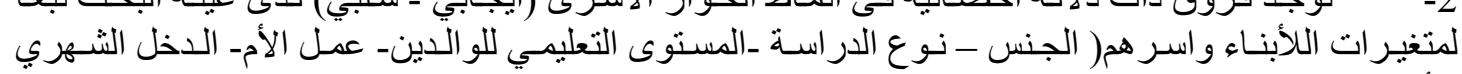

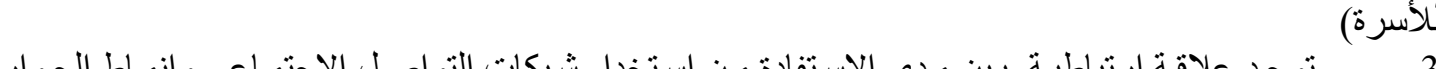
3- توجد علاقـة ارتباطيـة بين مدى الاستفادة من استخدام شبكات التو اصل الاجتمـاعي و انمـاط الحوار

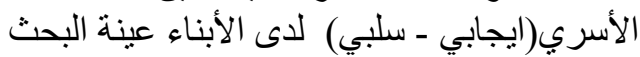

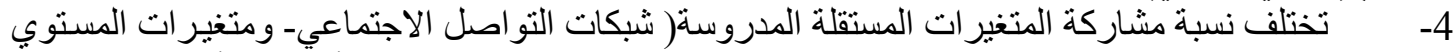
الاجتماعي و الاقتصـادي) في تفسير نسب التباين في المتغير التابع (انمـاط الحوار الأسري للأبناء) (ايجابي المصطلحات و المفاهيم النظرية للبحث:

شبكات التو اصل الاجتماعي: Social communication networks

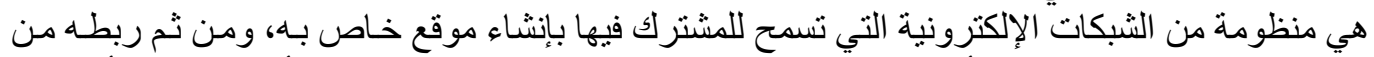

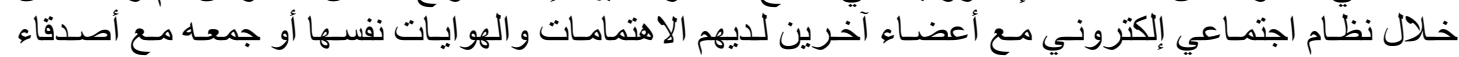
الجامعة أو الثانوية (زاهر الهر راضي، 2003)

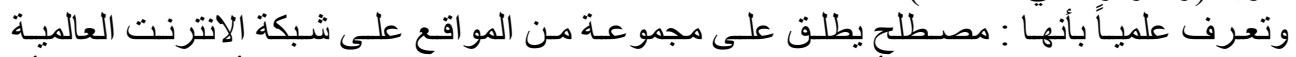

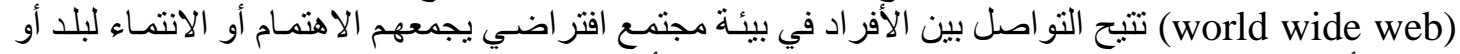
مدرسة أو فئة معينة، في نظام عالمي لنقل المعلومات (سلطان ألصاعدي، 2013) 


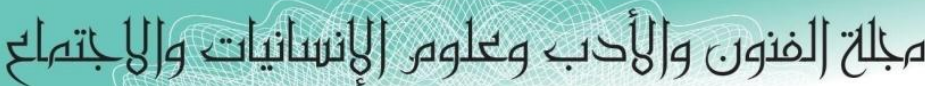

Journal of Arts, Literature, Humanities and Social Sciences

ISSN online: 2414 - 3383

ISSN print: 2616 - 3810

\section{العدد (42) أيلول - سبتمبر 2019}

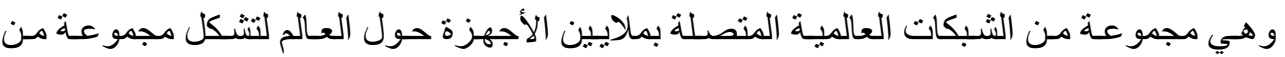

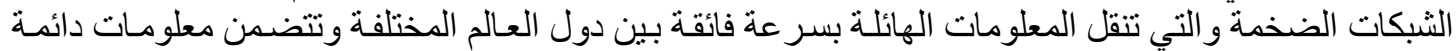
التطور (جمال الثرهان، 2003) و هي شبكات تتشكل من خلال الانترنت تسمح للأفر اد بتقديم لمحة عن حئ حياتهم العامة وإتاحة الفرصة للاتصال بقاعة المسجلين و التعبير عن وجهة نظر الأفر اد أو المجمو عات من خـلال عملية

الاتصال وتختلف طبيعة التو اصل من موقع لآخر (Danah and Nicole, B. 2013)

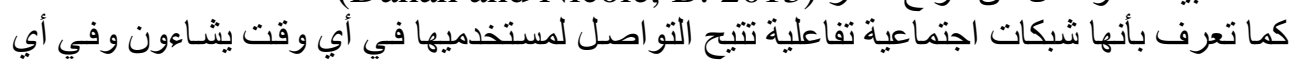

مكان من العالم و اكتسبت أسمها الاجتماعي كونها تعزز العلاقات بين البشر (أحمد حمودة، 2013).

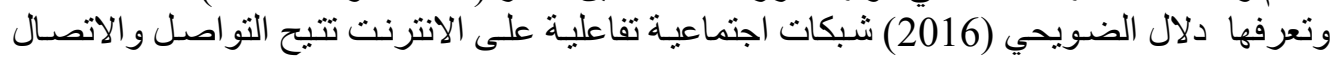

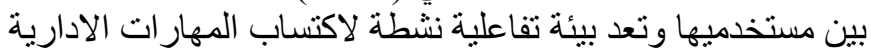

و القدر ات وتتمية المسئولية المجتمعية من خلال المثار كة الاجتماعية و المجتمعية في مختلف القضايا.

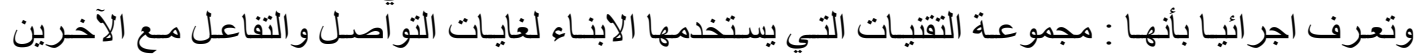
للاستفادة من خبر اتهح وخلق بيئة افتر اضية لهم توثر فيهم ونتكل سلوكم وتنمي ثقافة الحوار لديهم وتعزز انمـاط الحوار الابجابية. النمط:

هو سلوك الفرد المتكرر لفترة طويلـة مـن الزمن كمـا ير اه الآخرون ويعمل الفرد بموجبـه ويعتبره الإطـار العـام

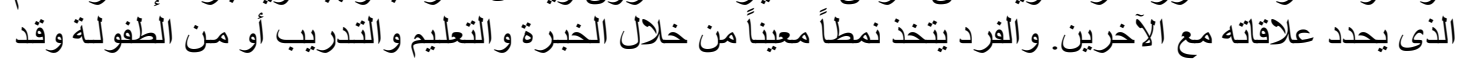

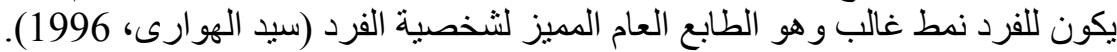

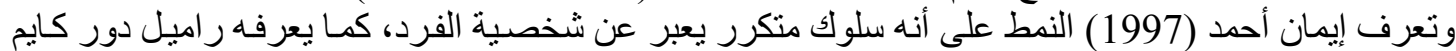

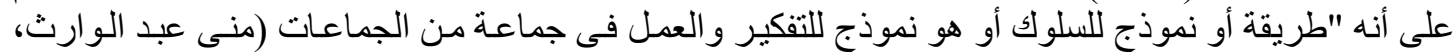

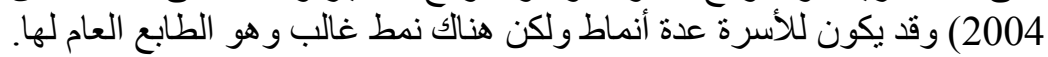
الحوار

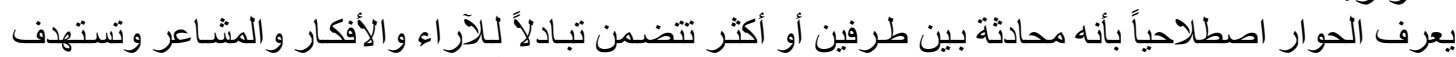

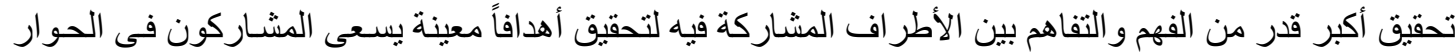

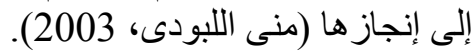

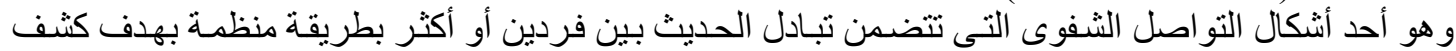

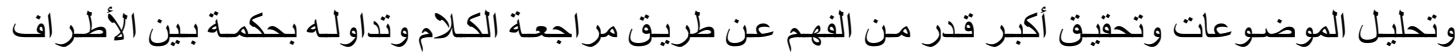
المشاركة فيه (ريم عبد العظيم، 2004).

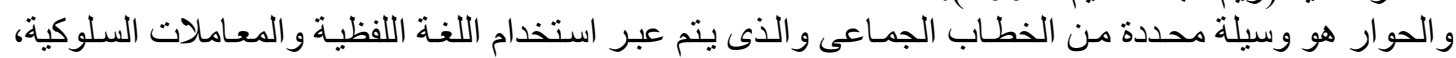
ويقوم على أساس التبادلية و علاقة المساو اة مع الآخر المختلف (Bela \& Patrick, 2005).

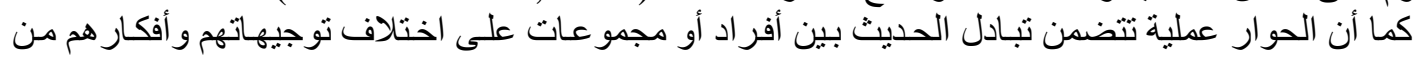

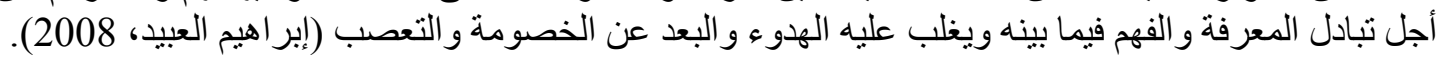

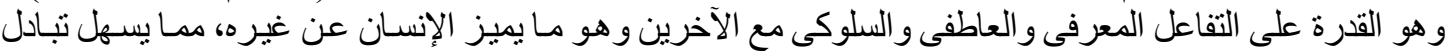
الخبرات و المفاهيم ونقلها بين الأجيال (كمال خليل، اعلى الفئ 2012).

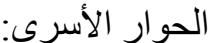

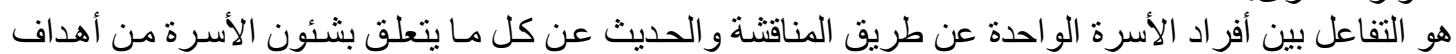

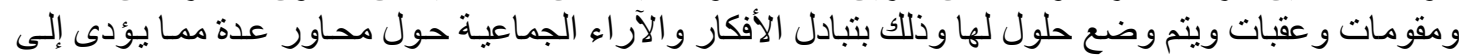

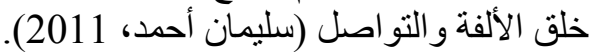

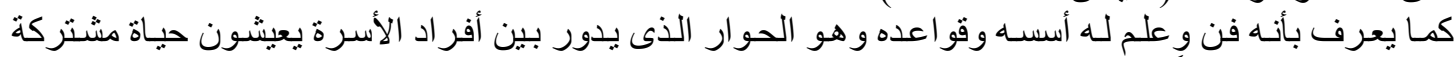
ويو اجهون حياتهم معاً (عبد القادر الثخلى لهنى، 1993 1993).

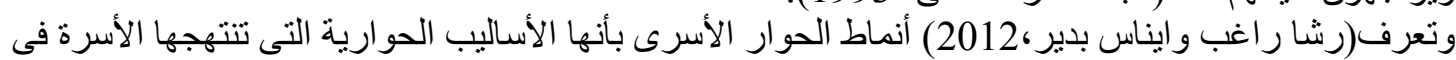
التو اصل مع أفر ادها وقد تكون إيجابية أو سلبية وتؤثر بشكل مباشر على أفكار وسلوكيات وشخصية أعضائها. 


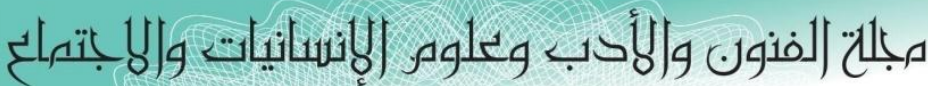

Journal of Arts, Literature, Humanities and Social Sciences

ISSN online: 2414 - 3383

ISSN print: 2616 - 3810

\section{العدد (42) أيلول - سبتمبر 2019}

وتعرف أنماط الحوار الاسري اجر ائيا بأنها اشكال التو اصل و الحوار الذي تتبعها الاسرة في تفاعلها مـع بعضـهـا

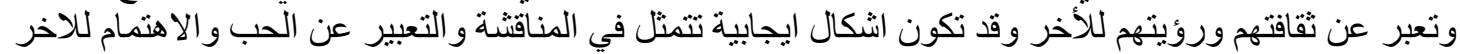

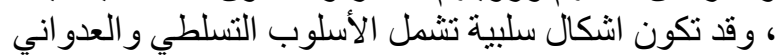

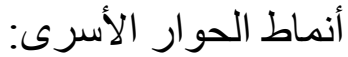

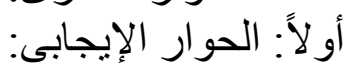

ويعرف بأنه حوار يساعد على دالإنى دم الرو ابط بين الزوجين وينمى لغة التفاهم مع الأبناء ينطلب مهارة فى التعبير

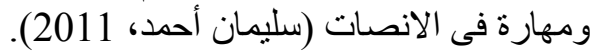

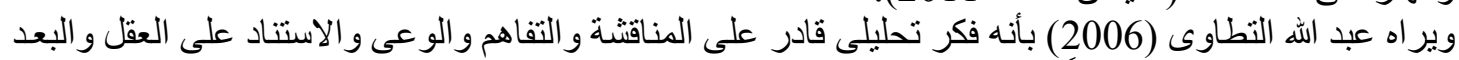

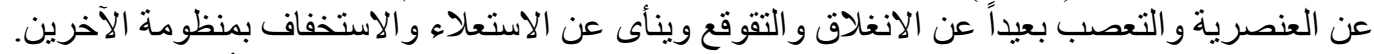

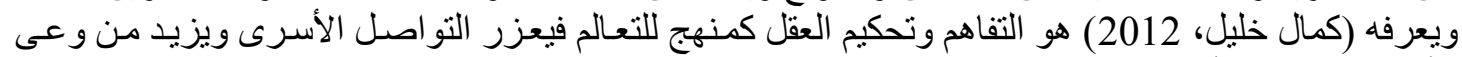

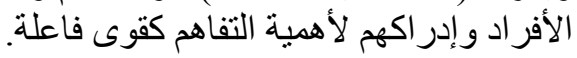

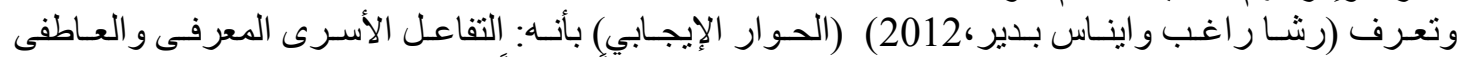

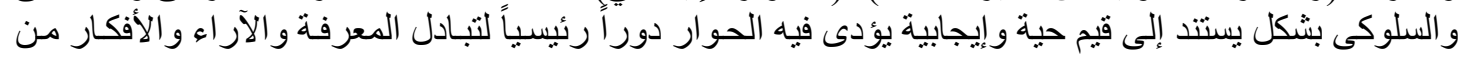

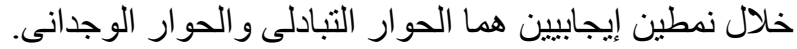
أنواع الحوار الإيجابى:

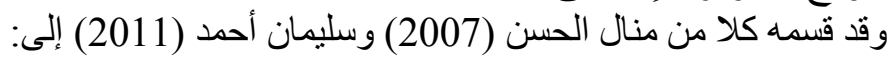

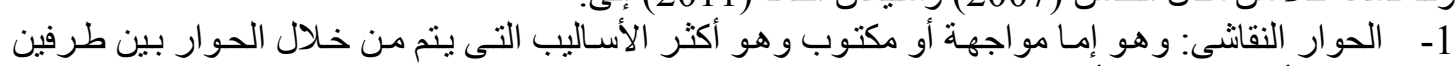

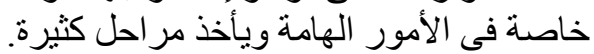

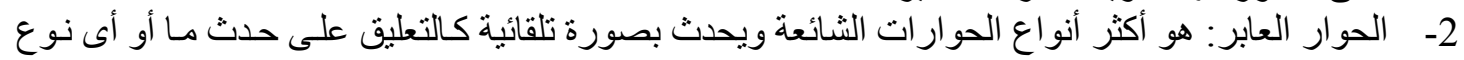

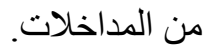
3- الحوار عن طريق العيون: وهى وسيلة للتعبير عن كثير من الكلام فنظر ات الإنسان وحركاته هى جزء من

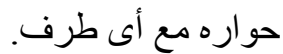

4- - الحوار العاطفي: وهو حو القو ار يتم فيه تبادل المشاعر العاطفية وأحاسيس كل طرف تجاه الطرف الآخر.

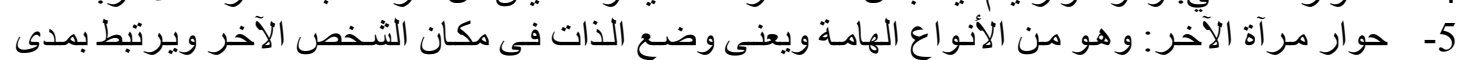

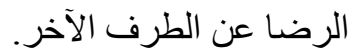
وقد رأت الباحثة تقسيم الحوار الإخر الإيجابي إلى نمطين رئيسيين هها:

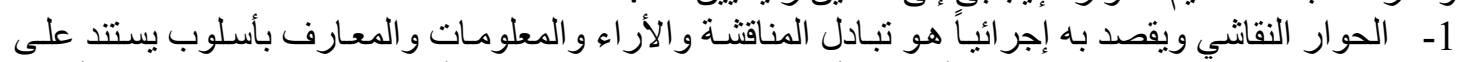

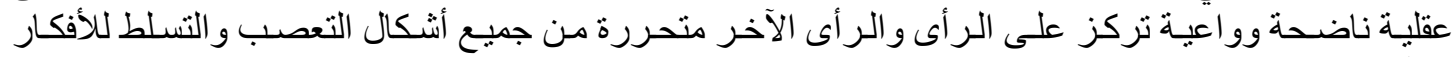
والآراء.

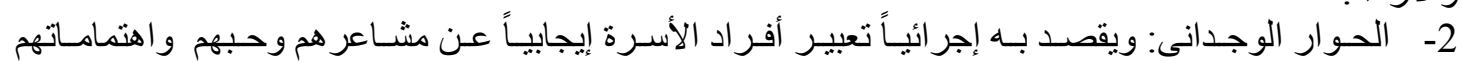

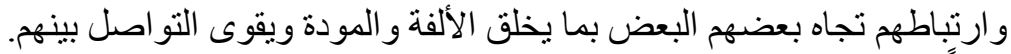

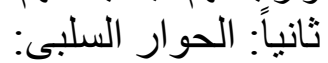

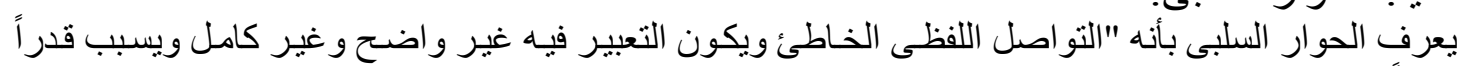

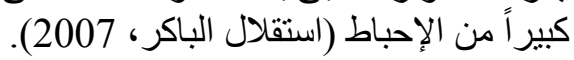

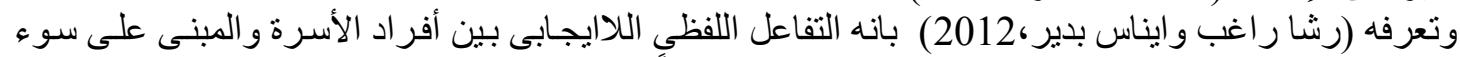

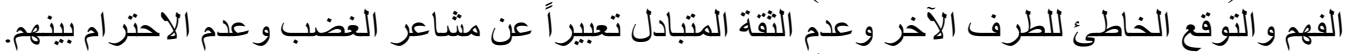

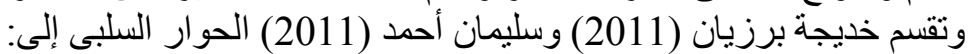

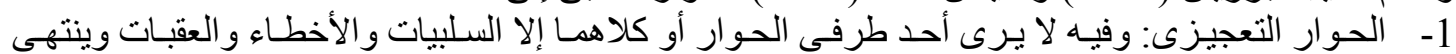
الحوار إلى أنه لا فائدة. 2- حوار المناورة: الكر و الفر حيث بنشغل أحد أطر اف الحوار بالتفوق اللفظى فى المناقشة بصرف النظر عن

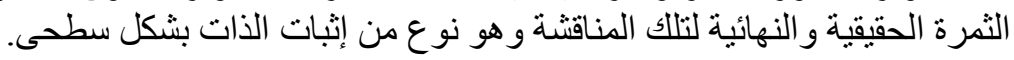




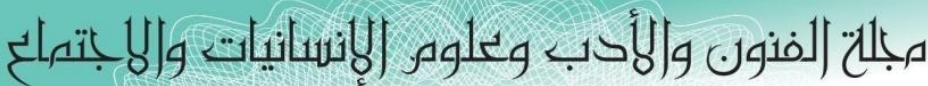

Journal of Arts, Literature, Humanities and Social Sciences

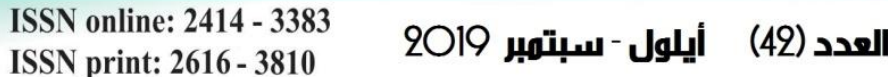

3- الحو ار المبطن: إعطاء ظاهر الكلام معنى غير ما يعطيه باطنه وذللك لكثرة ما بحتويه من التوريـة والألفاظ المبهمة و هو يهذف إلى إرباك الطرن الطرف الآخر.

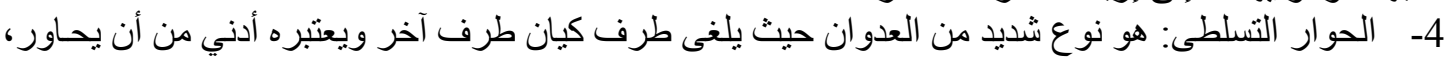

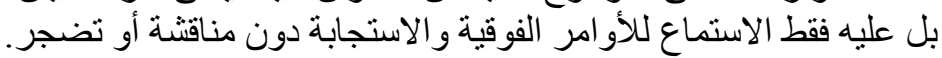
5- الحوار المغلق: هو نوع من التعصب و التطرف الفية الفكرى وانحسار مجال الرؤية ومبنى على عبارة (لا داعى

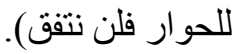

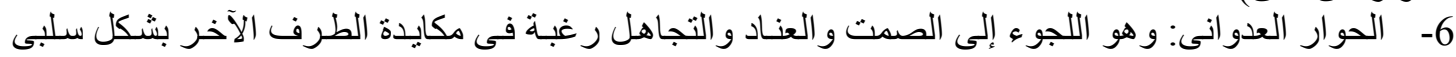
دون التعرض لخطر المواجهة العزان. وقد رأت الباحثة تقسيم الحوار السلبى إلى نمطين رئيسيين هى:

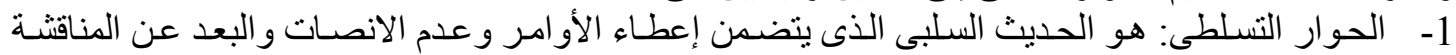
ويستند إلى التعصب وضيق الأفق وزيادة الثعور بالأنا و التسلط للأفكار و الآر اءواء. 2- الحوار العدو اني: هو الايذاء اللفظى للنفس المبنى على استخدام الألفاظ السيئة و الإحر اج و التجاهل التهل للطرف

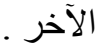

المر اهقة : Adolescence

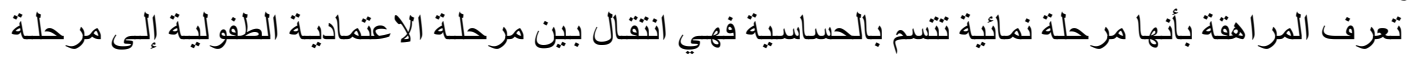

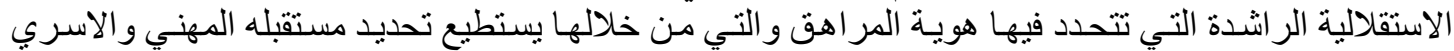

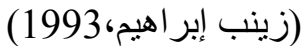

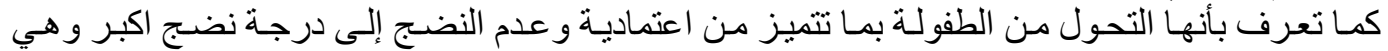

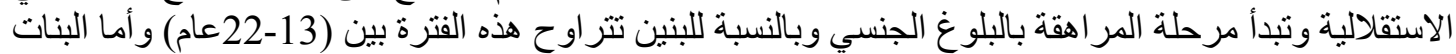

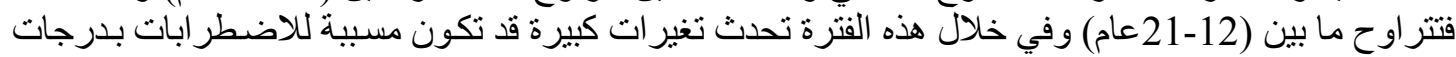

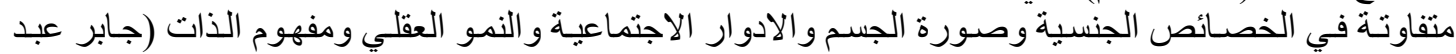
الحميد و علاء الدين كفافي، 1995)

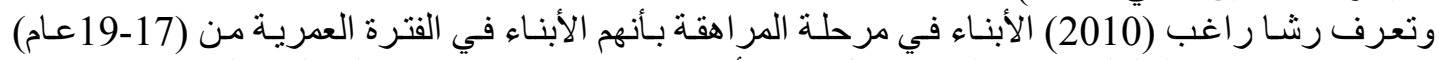
ويظهر فيها بوضوح السلوك الاستقلالي ويتفاعل فيها الأبناء تفاعلا ايجابيا مع بيئتهم الداخلية والخاء الخارجية. Children: الأبناء فيطاء

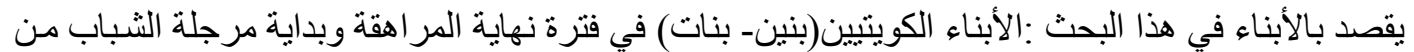

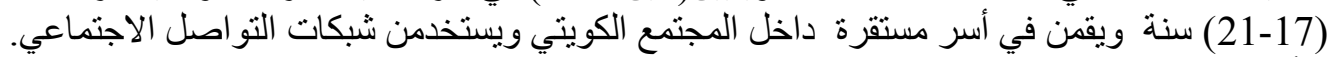

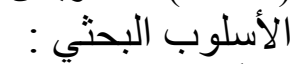
أولاً : منهج البحت: البحي:

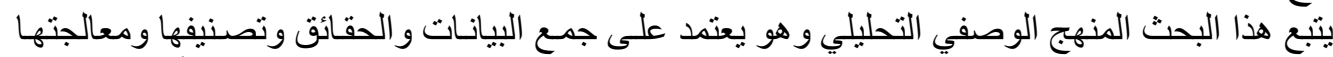

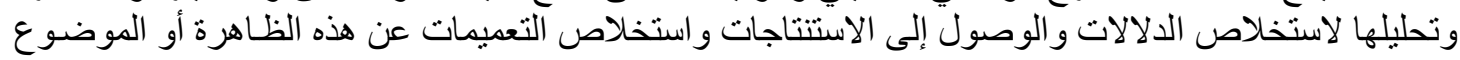

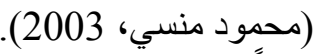
ثانياً : حدود البحد: منش: يتحدد هذا البحث على البح: :

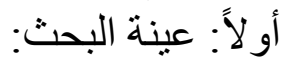

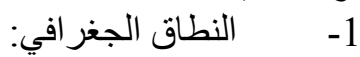
يتحدد النطاق الجغر افي في دولة الكويت.

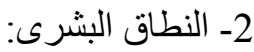

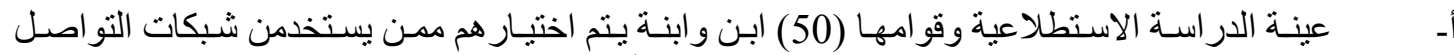
المجتمعي ويقعن تحت الفئة العمرية (17-217) سنة وذللك لتقنين أدو ات التهات الدراسة.

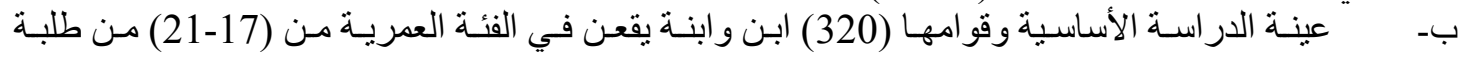




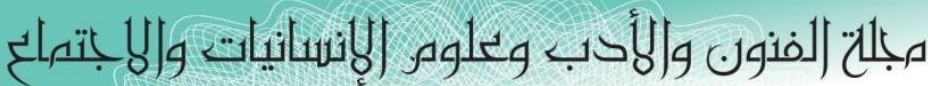

Journal of Arts, Literature, Humanities and Social Sciences

ISSN online: 2414 - 3383

ISSN print: 2616 - 3810

\section{العدد (42) ايلول -سبتمبر 2019}

وطالبات السنة الأولى و الثانية و الثالثة من كلية التربية الأساسة (الأقسام النظريـة والعملية) وكلية العلوم بجامعـة

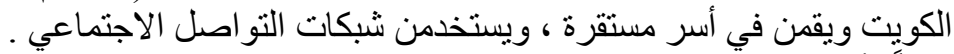

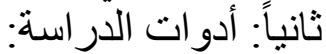

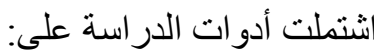

1 - استمارة البيانات العامة للأبناء وأسر هم: (إعداد الباحثة)

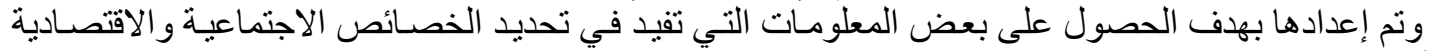

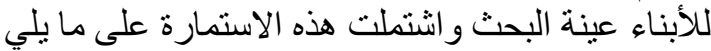

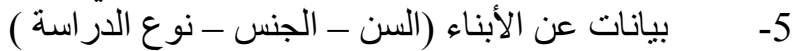

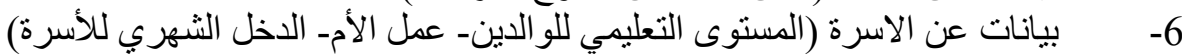

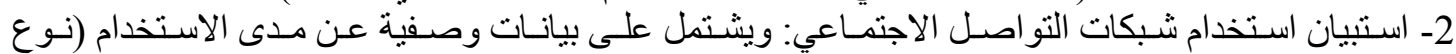

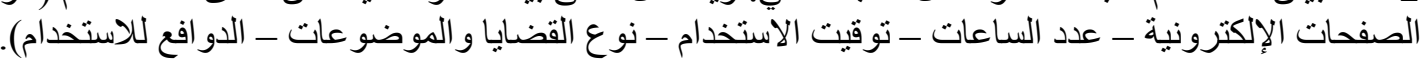
(إعداد الباحثة)

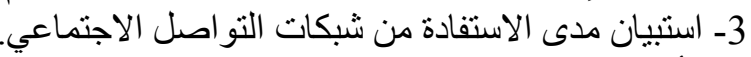

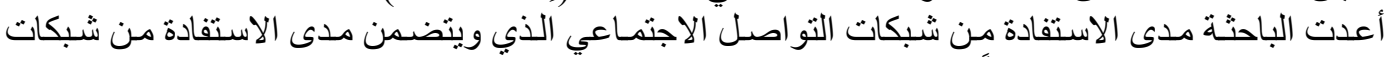

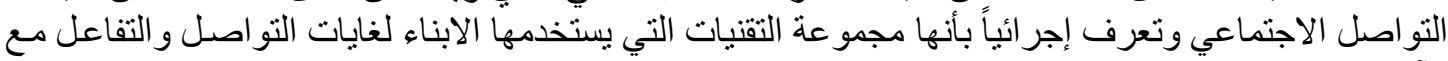

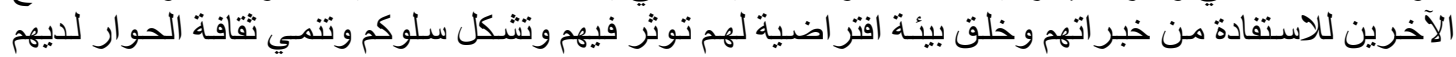

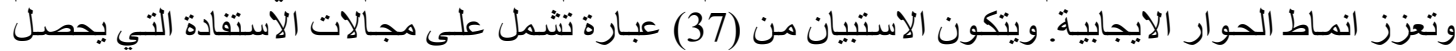

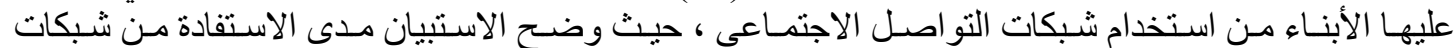

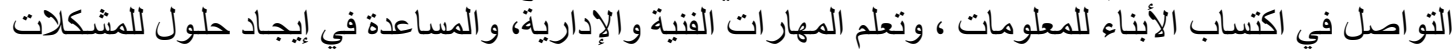

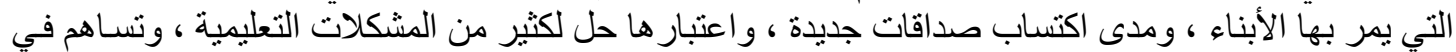

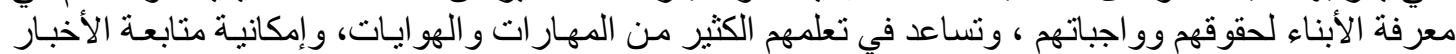

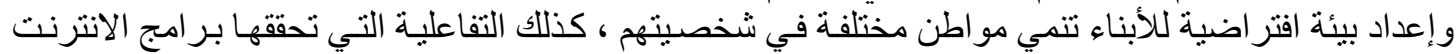

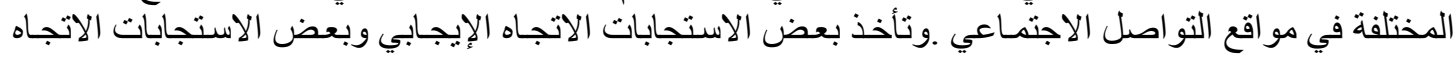

$$
\text { 3- أسلبي. مقياس أنماط الحوار الأسرى (إعداد الباحثة): }
$$

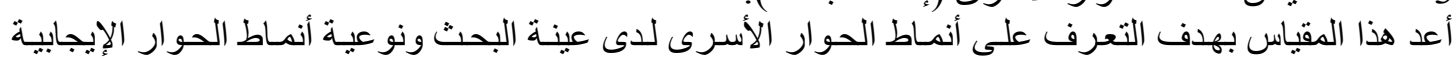

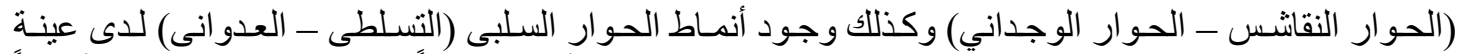

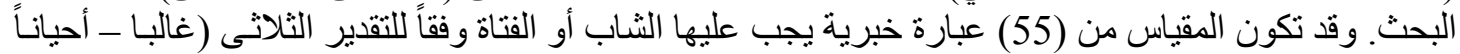

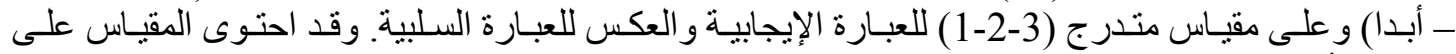
محورين أساسبين هما:

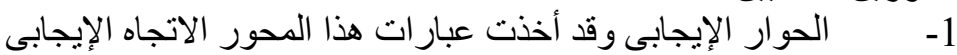

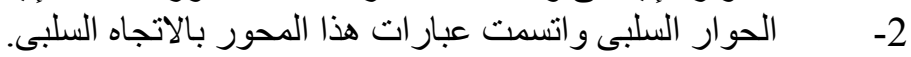
وتكون الحوار الإيجابى من محورين هما:

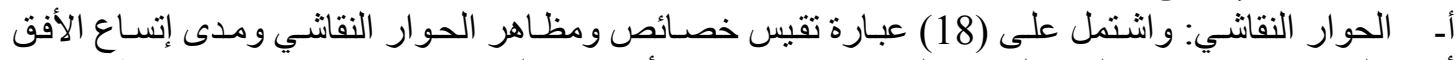

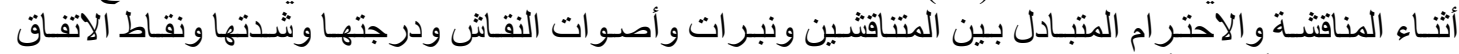
ومساحتها بين أفر اد الأسرة.

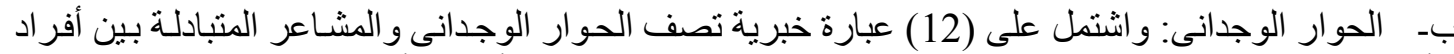

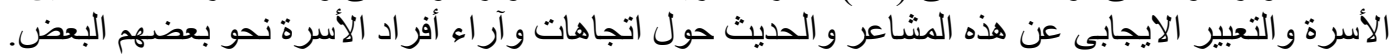

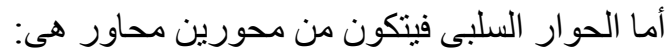

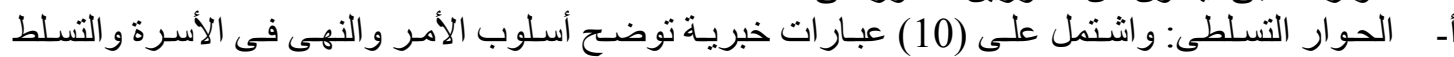

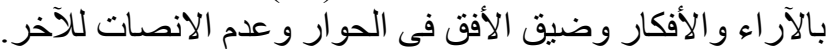

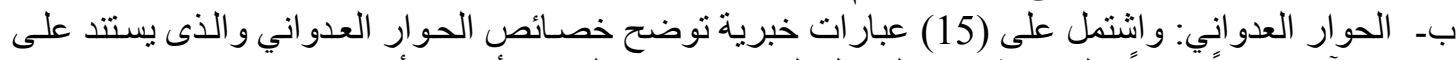
تجريح الآخر نفسياً وبدنياً والسخرية منه والتفاعل العصبي و الانفي التعالي بين أفر اد الأسرة. 


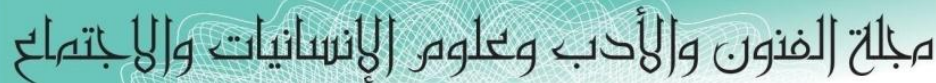

Journal of Arts, Literature, Humanities and Social Sciences

ISSN online: 2414 - 3383

ISSN print: 2616 - 3810

\section{العدد (42) ايلول - سبتمبر 2019}

تقنين الأدوات: ويقصد بها حساب صدق وثنات المقاييس. صدق المقاييس: تم التحقق من صدق أدو ات البون البحث بطريقتين.

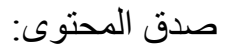

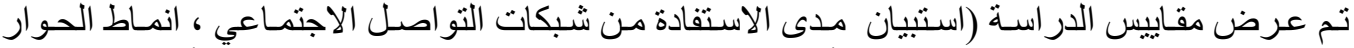

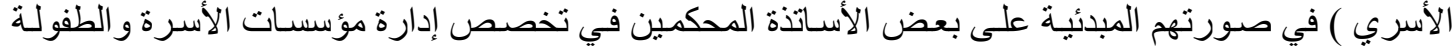

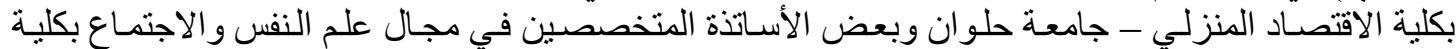

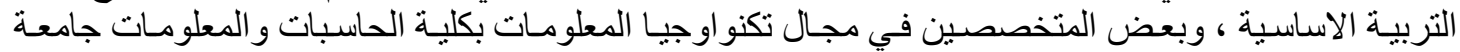

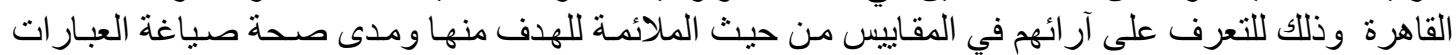

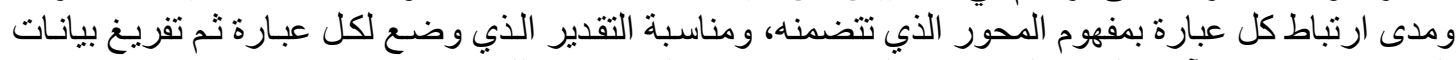

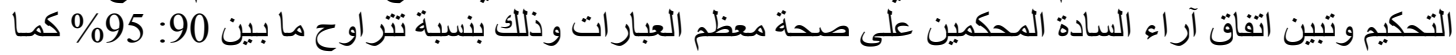

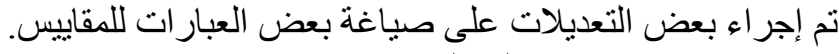

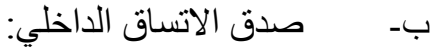

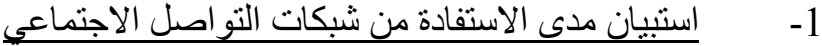

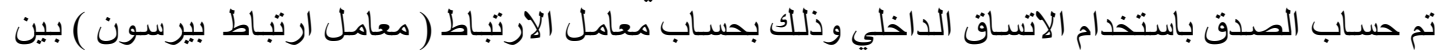

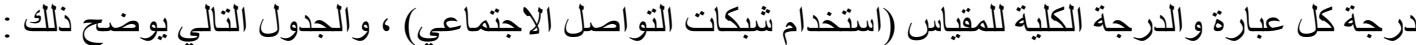

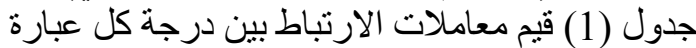

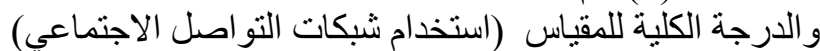

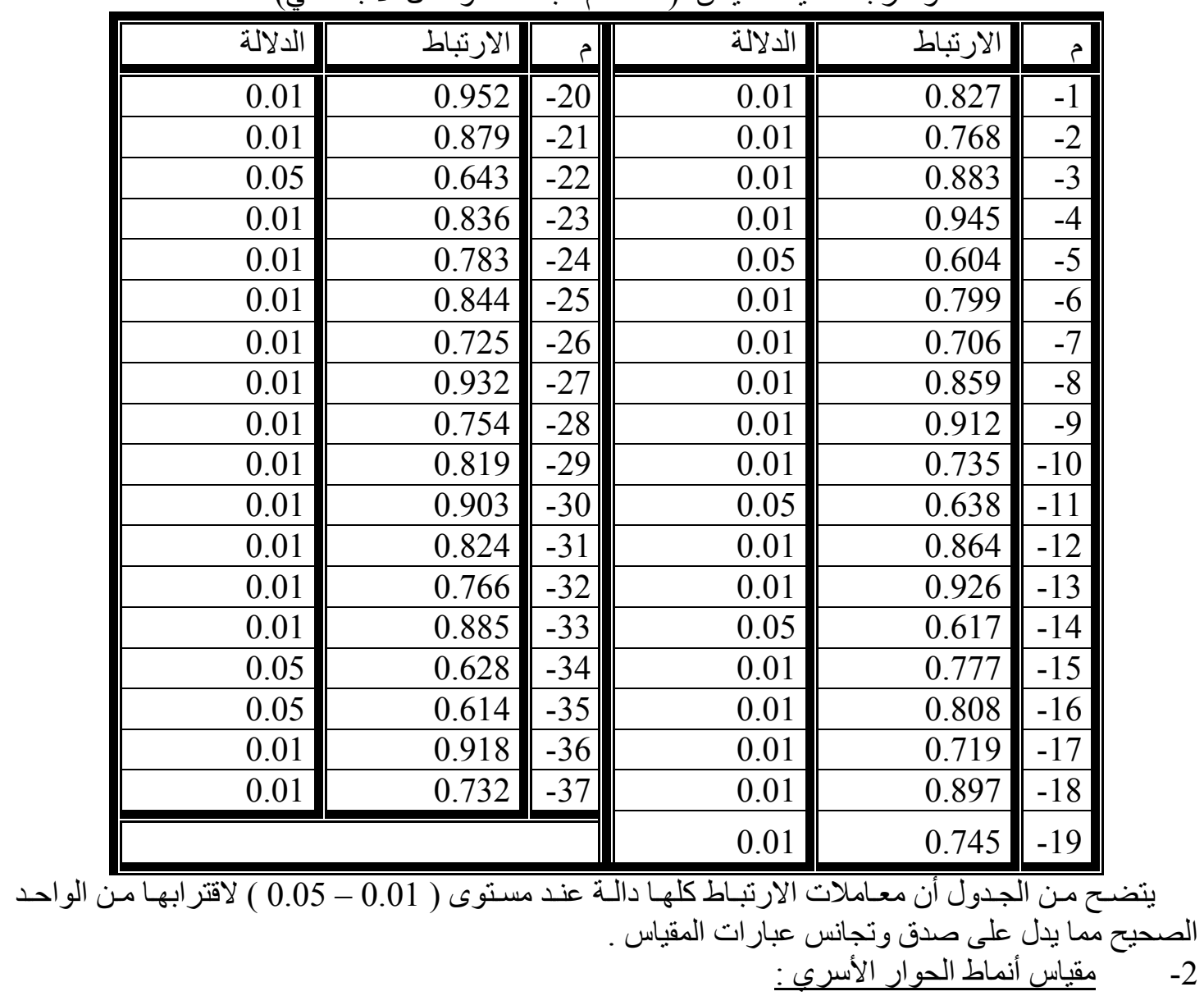




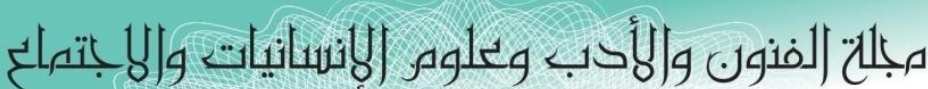
Joumal of Arts, Literature, Humanities and Social Sciences

ISSN online: 2414 - 3383

ISSN print: 2616 - 3810

\section{العدد (42) ايلول - سبتمبر 2019}

LALHSS

WWW.jalhss.com

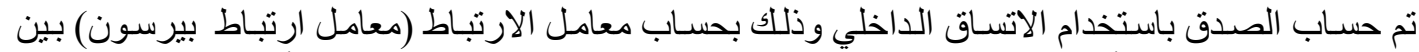

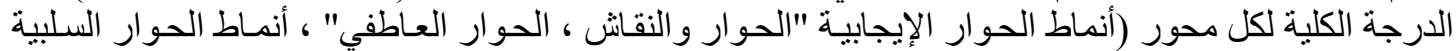

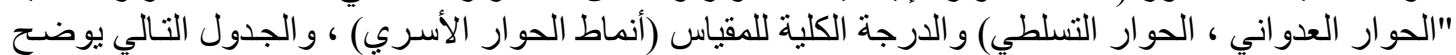

جدول (2) قبم معاملات الارتباط بين درجة كل محور ودرجة مقياس أنماط الحوار الأسري

\begin{tabular}{|c|c|c|}
\hline 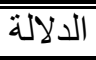 & الارتباط & مقياس انماط الحوار الأسري \\
\hline 0.01 & 0.797 & الدحور الأول : أنماط الحوار الإيجابية \\
\hline 0.01 & 0.856 & المحور الأول الفرعي : الحوار و النقاش \\
\hline 0.01 & 0.944 & المحور الثاني فرعي : الحوار العاطفي \\
\hline 0.01 & 0.705 & المحور الثاني : أنماط الحوار السلبية \\
\hline 0.01 & 0.866 & المحور الأول الفرعي : الحوار العدواني \\
\hline 0.01 & 0.804 & المحور الثاني فرعي : الحوار التسلطي \\
\hline
\end{tabular}

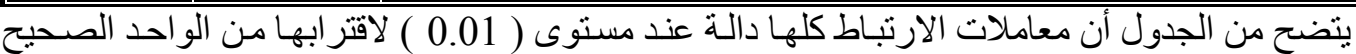

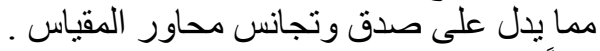
ثانياً: حساب ثبات المقاييس:

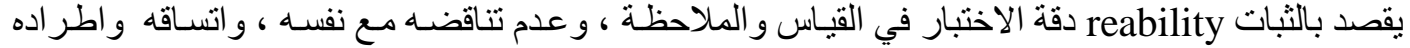

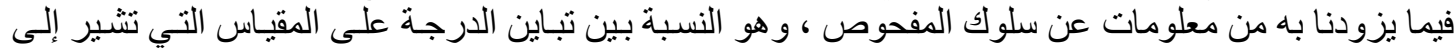

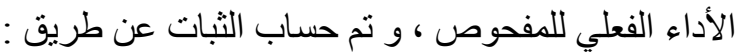

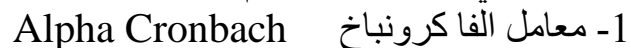
Split-half يقة التجزئة النصفية 3- جيوتمان Guttman جدول (3) قيم معامل الثبات لمقياس استخدام شبكات التو اصل الاجتماعي

\begin{tabular}{|c|c|c|c|}
\hline تمان & التجزئة النصفية & معامل الفا & \\
\hline 0.863 & $0.909-0.831$ & 0.875 & ثبات مقياس استخدام شبكات التو اصل الاجتماعي \\
\hline
\end{tabular}

يتضح من الجدول السابق أن جميع قيم معاملات الثبات : معامل الفا ، التجزئة النصفية ، جيوتمان دالة عند التئل مستوى 0.01 مما يدل على ثبات المقياس . جدول (4) قيم معامل الثبات لمحاور مقياس أنماط الحوار الأسري

\begin{tabular}{|c|c|c|c|}
\hline جيوتمان & التجزئة النصفية & معامل الفا & المحاور \\
\hline 0.802 & $0.845-0.777$ & 0.816 & المحور الأول : أنماط الحوار الإيجابية \\
\hline 0.783 & $0.829-0.752$ & 0.794 & المحور الأول الفرعي : الحوار والنقاش \\
\hline 0.910 & $0.957-0.881$ & 0.923 & المحور الثاني فرعي : الحوار العاطفي \\
\hline 0.764 & $0.808-0.732$ & 0.775 & المحور الثاني : أنماط الحوار السلبية \\
\hline 0.811 & $0.851-0.785$ & 0.827 & المحور الأول الفرعي : الحوار العدواني \\
\hline 0.731 & $0.776-0.703$ & 0.742 & المحور الثاني فرعي : الحوار التسلطي \\
\hline 0.846 & $0.882-0.817$ & 0.859 & ثبات مقياس أُنماط الحو ار الأسري ككل \\
\hline
\end{tabular}

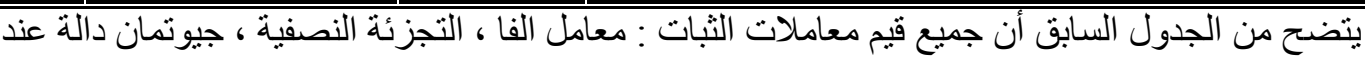
مستوى 0.01 مما يدل على ثبات المقياس . 


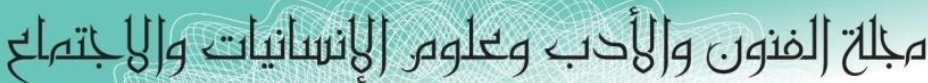

Journal of Arts, Literature, Humanities and Social Sciences

ISSN online: 2414 - 3383

ISSN print: 2616 - 3810

\section{العدد (42) ايلول - سبتمبر 2019}

LALHSS

www.jalhss.com

أجرى التطبيق الميداني على عينة البحث و المكونة من (320) من الأبناء وذلك في دولة الكويت وقد استغرق

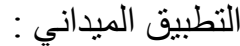
التطبيق ثناث أشهر هي من أول يناير إلى مارس- 2019.

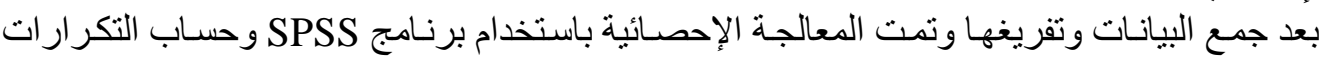

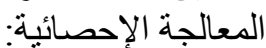

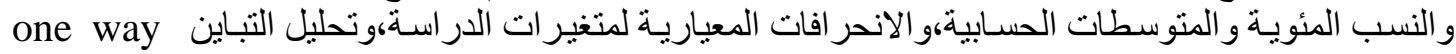

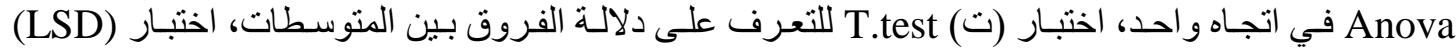
اللمقارنات المتعددة وحساب قيم معاملات ارتبات التباط بيرسون.

النتائج ومناقشتنها

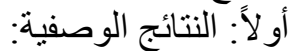

1- وصف العينة الأساسية من الأبناء: فيما يلى وصف شامل لعينة البحث موضحة فى جدول (5). جدول (5) وصف عينة البحث الأساسية (ن = 320)

\begin{tabular}{|c|c|c|c|}
\hline النسبة المئوية & العدد & الفئة & البيان \\
\hline$\% 45$ & 144 & ذكور & \multirow[t]{3}{*}{ الجنس } \\
\hline$\% 55$ & 176 & 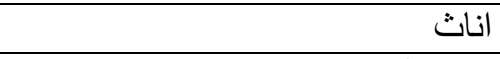 & \\
\hline$\% 100$ & 320 & 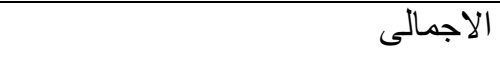 & \\
\hline$\% 63.8$ & 204 & كلبة التربية الاساسية (در اسة نظرية) & \multirow[t]{3}{*}{ التخصص } \\
\hline$\% 36.2$ & 116 & كلية العلوم (در اسة عملية) & \\
\hline$\% 100$ & 320 & الإجمالى & \\
\hline
\end{tabular}

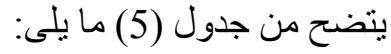

الجنس: أن أعلى نسبة من أفر اد العينة الأساسية من الطالبات بنسبة (55 \%) من العينة بينما بلغت نسبة الطلاب الذكور (45\%)

التخصص: أن غالبية أفراد العينة الأساسية كانو ايدرسن در اسة نظرية بنسبة (63.8\%) بينما كانوا الطلاب و الطالبات الذين

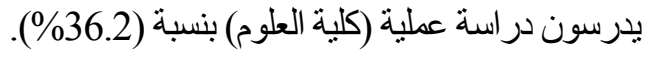
2- وصف متغيرات المستوى الاجتماعى و الاقتصادى لأسر عينة البحث:

\begin{tabular}{|c|c|c|c|}
\hline النسبة المئوية & العدد & الفئة & البيان \\
\hline$\% 11.9$ & 38 & الثهادة الابتدائية فأقل & \multirow{4}{*}{ المستوى التعليمى للأب } \\
\hline$\% 20$ & 64 & الشهادة المتوسطة & \\
\hline$\% 28.4$ & 91 & الثهادة الثانوية / دبلوم & \\
\hline$\% 39.7$ & 127 & الثهادة الجامعية "ماجستير ، دكتور اه" & \\
\hline
\end{tabular}




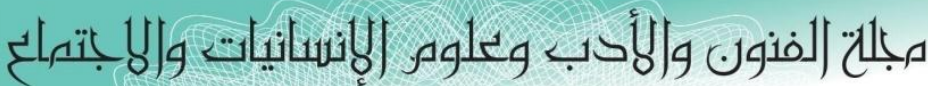

Journal of Arts, Literature, Humanities and Social Sciences

ISSN online: 2414 - 3383

ISSN print: 2616 - 3810

العدد (42) أيلول -سبتهبر 2019

LALHSS

WWw.jalhss.com

\begin{tabular}{|c|c|c|c|}
\hline$\% 100$ & 320 & المجموع & \\
\hline$\% 15.3$ & 49 & الثهادة الابتدائية فأقلّل & \multirow[t]{5}{*}{ الكستوى التعليمى للأم } \\
\hline$\% 18.8$ & 60 & الثهادة المتوسطة & \\
\hline$\% 27.5$ & 88 & الثهادة الثانوية / دبلوم & \\
\hline$\% 38.4$ & 123 & الثهادة الجامعية "ماجستير ، دكتور اه" & \\
\hline$\% 100$ & 320 & المجموع & \\
\hline$\overline{0 \% 58.8}$ & 188 & تعمل & \multirow[t]{3}{*}{ عمل الام } \\
\hline$\% 41.2$ & 132 & لا لتعل & \\
\hline$\% 100$ & 320 & المجموع & \\
\hline \%13.8 & $\overline{44}$ & اقل من 400 دينار & \multirow{6}{*}{ الدخل الثهرى للأسرة } \\
\hline$\% 19.4$ & 62 & من 400 دينار إلى اقل من 800 دينار & \\
\hline$\% 17.5$ & 56 & من 800 دينار إلى اقل من 1200 دينار & \\
\hline$\% 25.9$ & 83 & دينار 1200 دينــار إلـى اقـل مــن 1600 & \\
\hline$\% 23.4$ & 75 & من 1600 دينار فأكثر & \\
\hline$\% 100$ & 320 & المجموع & \\
\hline
\end{tabular}

- المستوى التعليمى للأب: أن غالبية أفر اد العينة الأساسية كان المستوى التعليمى للأب مرتفع (جامعى وفوق

جامعى) بنسبة (39.7\%) بينما كانت أقل نسبة للمستوى التعليمى المنخفض (تعليم ابتدائي) بنسبة (11.9\%).

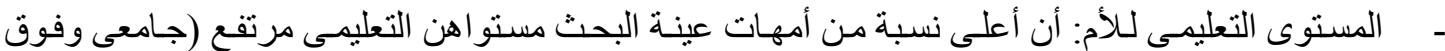
جامعى) بنسبة (38.4\%) بينما أقل نسبة منهن كان مستو اهن التعليمى منخفض بنسبة (15.3\%).

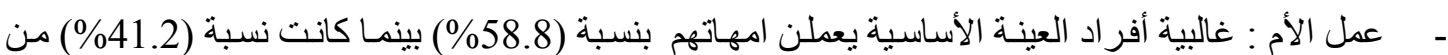

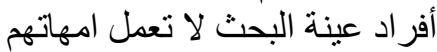

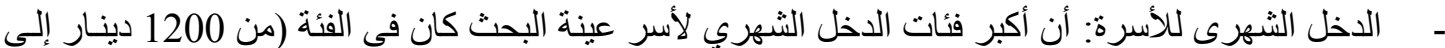

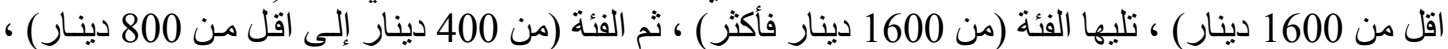

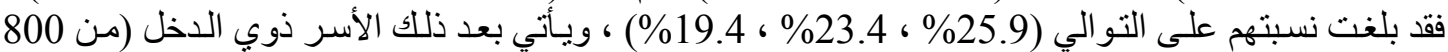

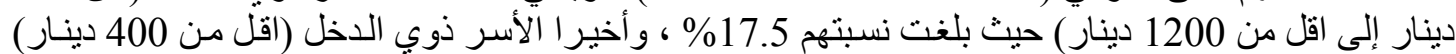

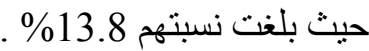
3- وصف استخدام عينة البحث لثبكات التو اصل الاجتماعي:

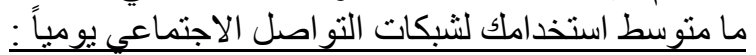

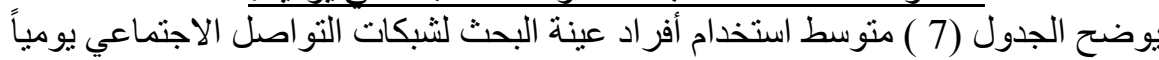




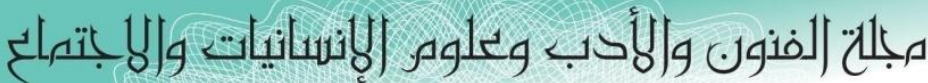

Joumal of Arts, Literature, Humanities and Social Sciences

ISSN online: 2414 - 3383

ISSN print: 2616 - 3810

\section{العدد (42) ايلول - سبتمبر 2019}

LALHSS

www.jalhss.com

جدول ( 7) متوسط استخدام أفر اد عينة البحث لثبكات التو اصل الاجتماعي يومياً

\begin{tabular}{|c|c|c|}
\hline النسبة\%\% & | العدد & 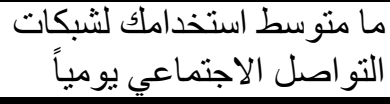 \\
\hline$\% 11.3$ & 36 & أقلّ من ساعة \\
\hline$\% 38.1$ & 122 & من ساعة إلى ساعتين \\
\hline$\% 50.6$ & 162 & أكثر من ساعتين \\
\hline$\% 100$ & 320 & المجموع \\
\hline
\end{tabular}

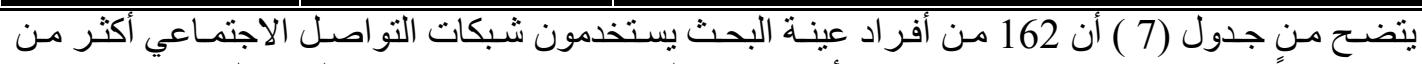

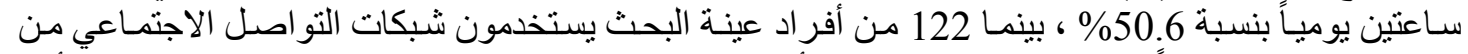

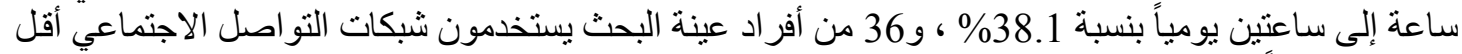

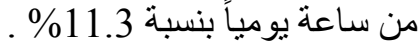

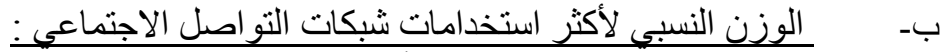
يوضح الجدول (8 ) الوزن النسبي لأكثر استخدامات شبكات النّات النتواعل الإنتماعي

جدول (8 ) الوزن النسبي لأكثر استخدامات شبكات التو اصل الاجتماعي

\begin{tabular}{|c|c|c|c|}
\hline الترتيب & النسبة المئوية\%\% & الوزن النسبي & استخدامات شبكات التو اصل الاجتماعي \\
\hline الأول & $\% 12.3$ & 397 & الو اتساب \\
\hline 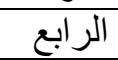 & $\% 11.4$ & 367 & 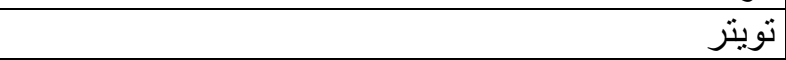 \\
\hline الثاني & $\% 12$ & 388 & الانستجر ام \\
\hline 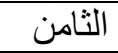 & $\% 9.9$ & 323 & (الفلبكر - بينتزريست للصور ) \\
\hline السادس - اس & $\% 10.8$ & 348 & جوجل بلس \\
\hline 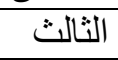 & $\% 11.6$ & 374 & سناب شات \\
\hline 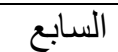 & $\% 10.6$ & 342 & 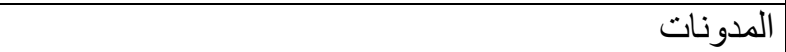 \\
\hline 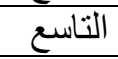 & $\% 10.4$ & 337 & الفيس بوك \\
\hline 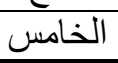 & $\% 11$ & 356 & المحادثات (سكاب بي- وماسنجر - تانجو - فيس تايم- فايير ) \\
\hline & $\% 100$ & 3232 & المجموع \\
\hline
\end{tabular}

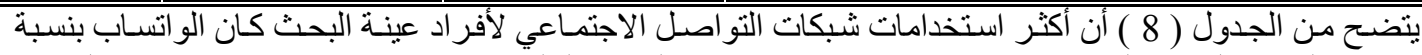

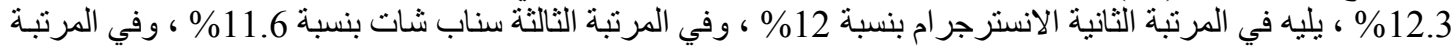

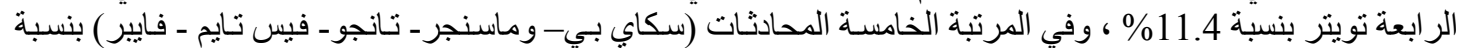

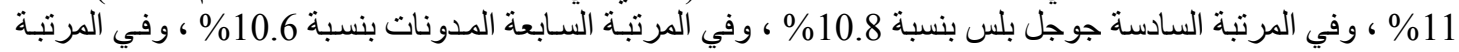

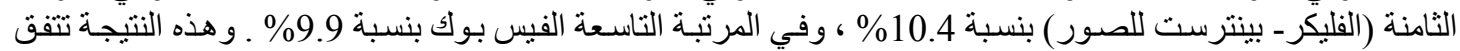

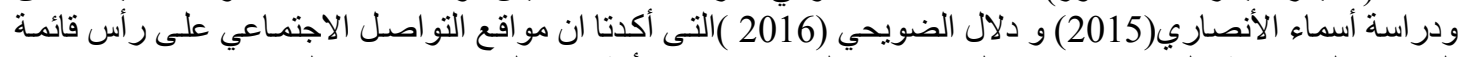

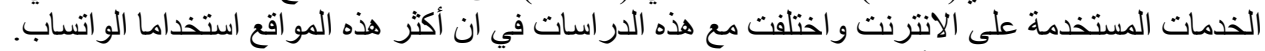

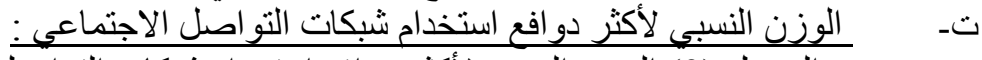

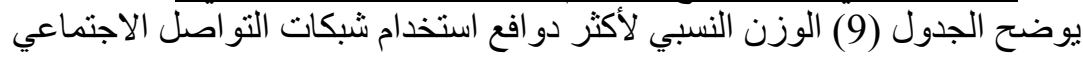




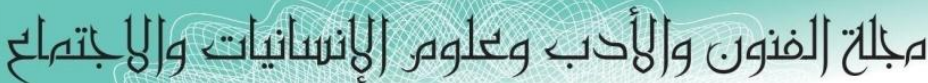
Joumal of Arts, Literature, Humanities and Social Sciences

ISSN online: 2414 - 3383

ISSN print: 2616 - 3810

\section{العدد (42) ايلول - سبتمبر 2019}

جدول (9) الوزن النسبي لأكثر دو افع استخدام شبكات التو اصل الاجتماعي

\begin{tabular}{|c|c|c|c|}
\hline الترتيب & النسبة المئويةز\% & الوزن النسبي & دو افع استخدام شبكات التو اصل الاجتماعي \\
\hline 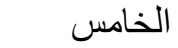 & $\% 7.3$ & 462 & الحصول على معلومات متنو عة في مجالات مختلفة \\
\hline 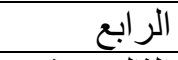 & $\% 7.5$ & 477 & وسيلة تفاعلية تتيح التو اصل مع الآخرين \\
\hline الثالث عشر & $\% 5.4$ & 344 & التعرف على ثقافات جديدة \\
\hline 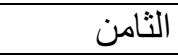 & $\% 6.8$ & 429 & زيادة معلوماتي حول القضايا المهمة في المجتمع \\
\hline 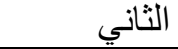 & $\% 8.1$ & 510 & مو اكبة الأحداث و التغير ات المجتمعية \\
\hline 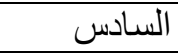 & $\% 7.1$ & 451 & التسلية وقضاء وقت الفراغ \\
\hline الأول & $\% 8.3$ & 526 & اكتساب مهار ات وخبر ات جديدة \\
\hline 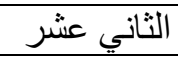 & $\% 5.7$ & 358 & حب الاستطلاع ومشاهدة الصور و الفيديو هات \\
\hline 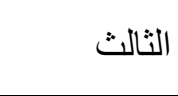 & $\% 7.8$ & 493 & تعزيز قدر اتي في إدارة النقاش في الموضو عات العامة \\
\hline الحادي عشر & $\% 5.8$ & 369 & تمكنني من القدرة على تحليل الأحداث \\
\hline السابع & $\% 6.9$ & 437 & الوصول إلى كم هائل من المعلومات بأقصى سر عة \\
\hline الخامس عشر & $\% 5.1$ & 324 & الحرية في التعبير عن الرأي \\
\hline التاسع & $\% 6.6$ & 418 & تكوين صداقات جديدة \\
\hline العاشر & $\% 6.2$ & 391 & شر اء المنتجات والتسوق \\
\hline الرابع عشر & $\% 5.3$ & 336 & المعرفة فيما بخص در استي \\
\hline & $\% 100$ & 6325 & \\
\hline
\end{tabular}

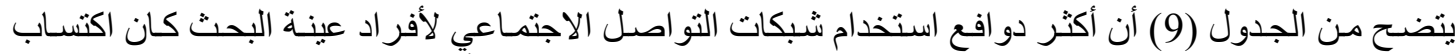

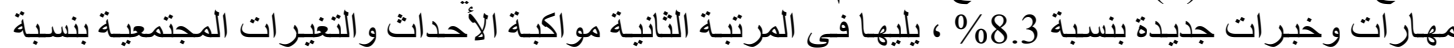

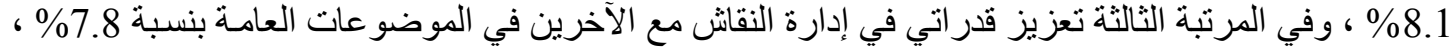

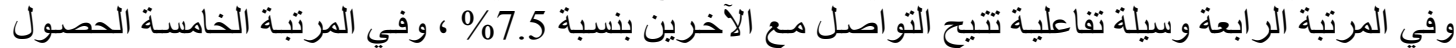

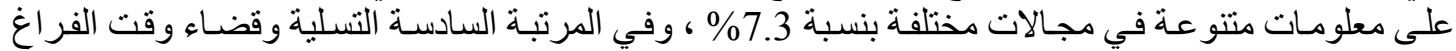

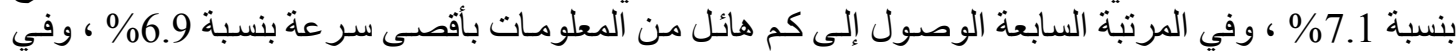

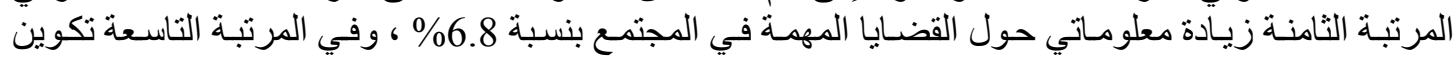

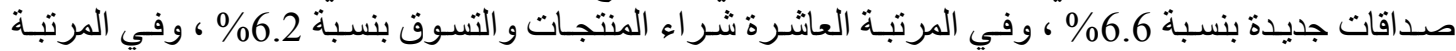

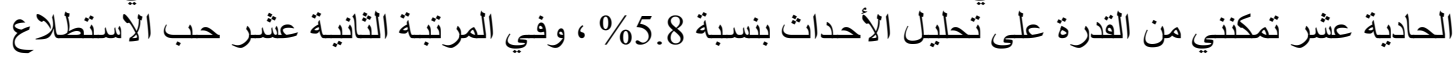

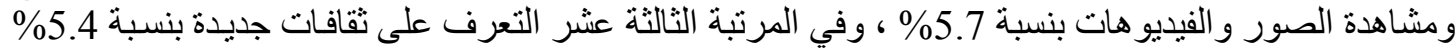

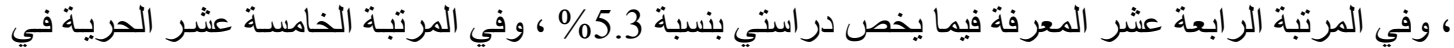

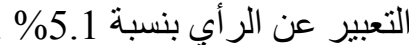

4- تختلف الأوزان النسبية لأكثر أنماط الحوار الأسري لأفر اد عينة البحث جدول (10) الوزن النسبي لأكثر أنماط الحوار الأسري لألفر الأفر اد عينة البحث

\begin{tabular}{|c|c|c|c|}
\hline الترتيب & النسبة المئوية\%\% & الوزن النسبي & أنماط الحوار الأسري \\
\hline الأول & $\% 53.2$ & 422 & أنماط الحوار الإبجابية \\
\hline التاني & $\% 46.8$ & 371 & أنماط الحوار السلبية \\
\hline & $\% 100$ & 793 & \\
\hline
\end{tabular}




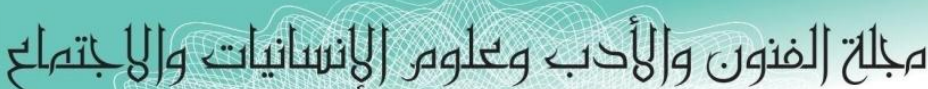
Journal of Arts, Literature, Humanities and Social Sciences

ISSN online: 2414 - 3383

ISSN print: 2616 - 3810

\section{العدد (42) ايلول - سبتمبر 2019}

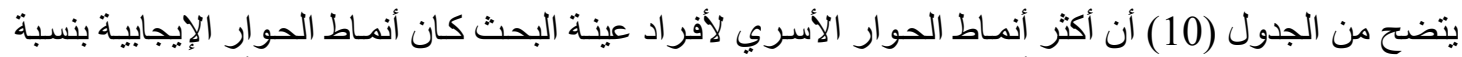

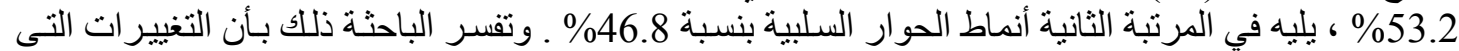

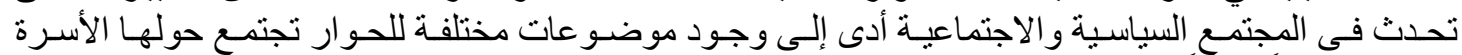

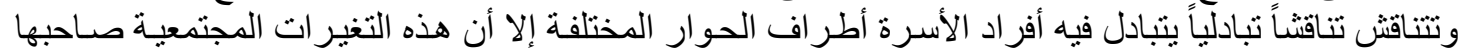

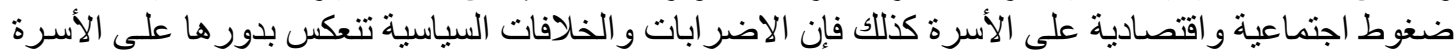

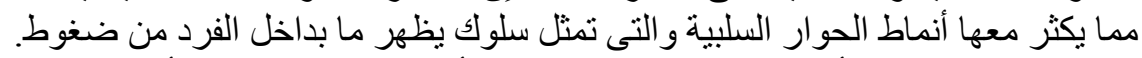

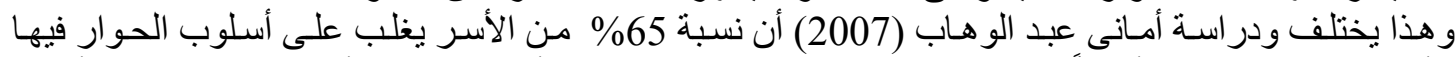

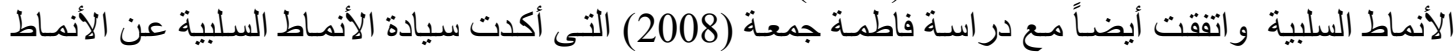

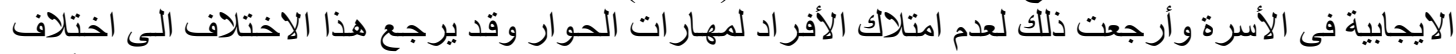

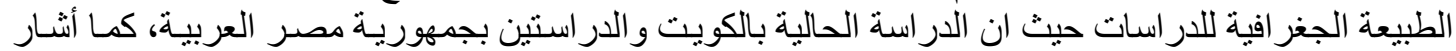

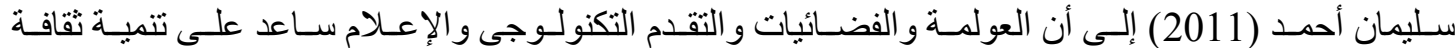
الديمقر اطية وتبادل الحوار وهو ما ساعد على النتشار الحوار النقار النقاشتى أو المناقتشة البناءة.

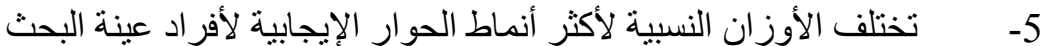
جدول (11) الوزن النسبي لأكثر أنماط الإندابة الحوار الإيجابية لأفر اد عينة البحث

\begin{tabular}{|c|c|c|c|}
\hline الترتيب & النسبة المئوية\%\% & الوزن النسبي & أنماط الحوار الإيجابية \\
\hline الأول & $\% 51.3$ & 367 & الحوار و النقاش \\
\hline 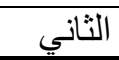 & $\% 48.7$ & 349 & الحوار العاطفي \\
\hline & $\% 100$ & 716 & المجموع \\
\hline
\end{tabular}

يتضح من الجدول (11 ) أن أكثر أنماط الحوار الإيجابية لأفراد عينة البحث كان الحوار والنقاش بنسبة

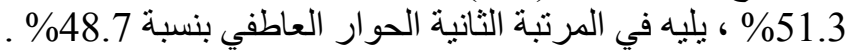

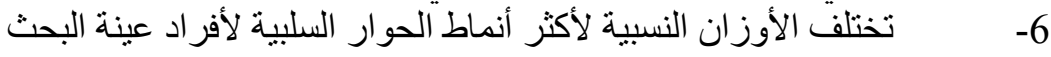

جدول (11) الوزن النسبي لأكثر أنماط الحوار السلبية لأفر اد عينة البحث

\begin{tabular}{|c|c|c|c|}
\hline الترتيب & النسبة المئوية\%\% & الوزن النسبي & أنماط الحوار السلبية \\
\hline التثاني & $\% 47.7$ & $\overline{356}$ & الحوار العدواني \\
\hline الأول & $\% 52.3$ & 391 & الحوار التسلطي \\
\hline & $\% 100$ & 747 & $\varepsilon$ \\
\hline
\end{tabular}

يتضح من الجدول (11) أن أكثر أنماط الحوار السلبية لأفراد عينة البحث كان الحوار التسلطي بنسبة

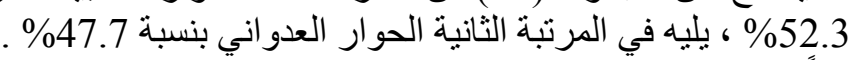

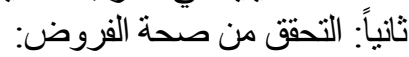

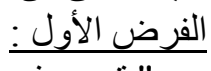

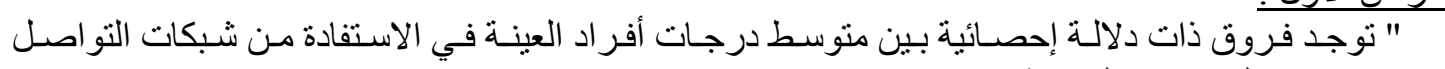

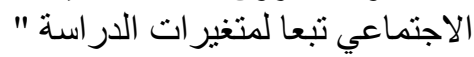

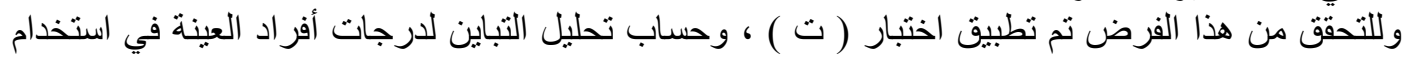

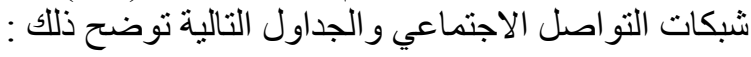




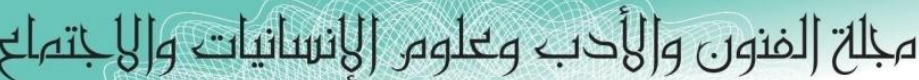

Journal of Arts, Literature, Humanities and Social Sciences

ISSN online: 2414 - 3383

ISSN print: 2616 - 3810

\section{العدد (42) ايلول - سبتمبر 2019}

LALHSS

Www.jalhss.com

جدول ( 12) الفروق في منوسط درجات أفراد العينة في استخدام شبكات التواصل الاجتماعي تبعا لمتغير الجنس

\begin{tabular}{|c|c|c|c|c|c|c|}
\hline الدلالة & قيمة ( ت ) & درجات & العينة & الانحر افياري & المتوسط الحسبي & الجنس \\
\hline \multirow{2}{*}{ لصال عند 0.01 دالح الذكور } & \multirow{2}{*}{13.628} & \multirow{2}{*}{318} & 144 & 7.881 & 102.514 & ذكور \\
\hline & & & 176 & 5.096 & 88.304 & إناث \\
\hline
\end{tabular}

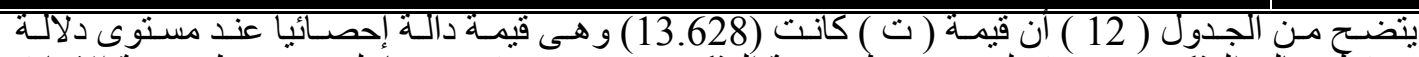

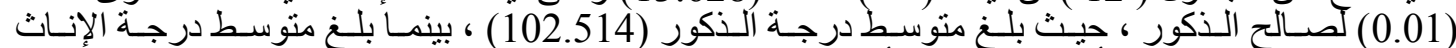

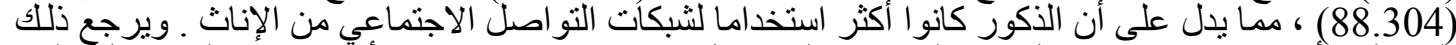

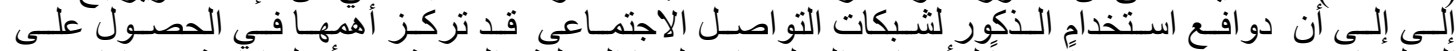

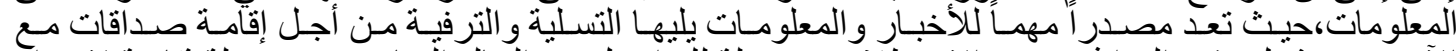

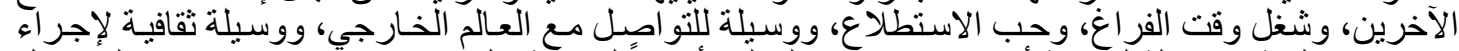

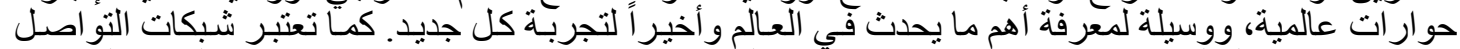

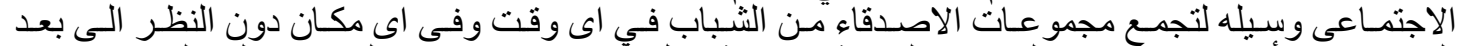

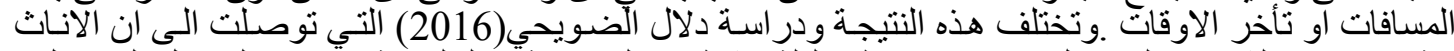

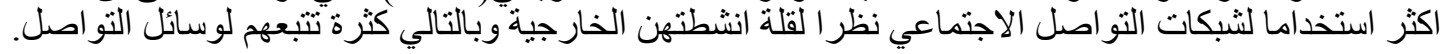

جدول (13 ) الفروق في منوسط درجات أفر اد العينة في استخدام شبكات التو اصل الاجتماعي تبعا لمتغير نوع الدرأسة السئة

\begin{tabular}{|c|c|c|c|c|c|c|}
\hline الدلالة & قيمة (ت) & الحرجية & العينة & الالنحراف & الحسابي & نوع الدر اسة \\
\hline \multirow{2}{*}{ لدال عند نظرية } & \multirow{2}{*}{24.193} & \multirow{2}{*}{318} & 204 & 5.413 & 99.881 & نظرية \\
\hline & & & 116 & 4.389 & 71.069 & عملية \\
\hline
\end{tabular}

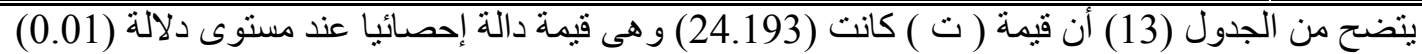

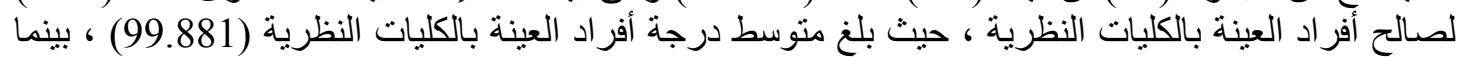

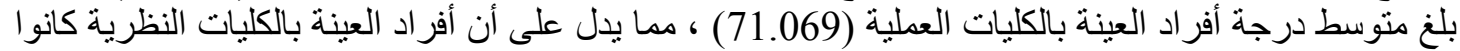

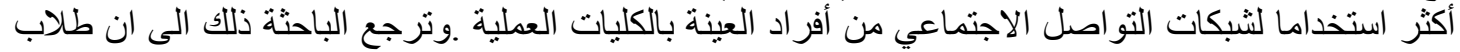

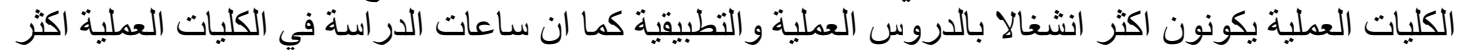

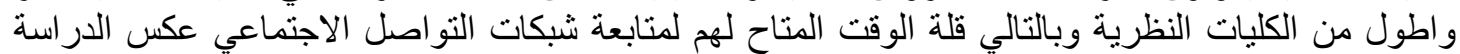
النظرية. جدول ( 14) تحليل التباين لدرجات أفر اد العينة في استخدام شبكات التو اصل الاجتماعي تبعا لتتغير تعليم الأب

\begin{tabular}{|c|c|c|c|c|c|}
\hline الدلالة & قيمة ( ف) & الحرية & متوسط المربعات & مجموع المربعات & تعليم الأب \\
\hline \multirow{2}{*}{0.010} & \multirow{2}{*}{56.622} & 2 & 4075.450 & 8150.900 & بين المجمو عات \\
\hline & & 317 & 71.976 & 22816.516 & داخل المجمو عات \\
\hline & & 319 & & 30967.416 & مجموع \\
\hline
\end{tabular}

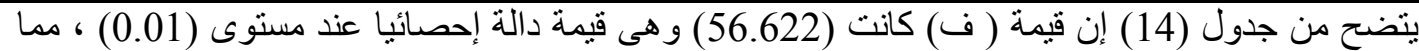

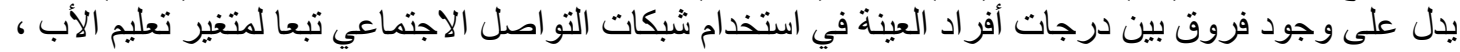
ولمعرفة اتجاه الدلالة تم تطبيق اختبار LSD للمقارنات المتعددة والجدول التالي يوضح ذللك : 


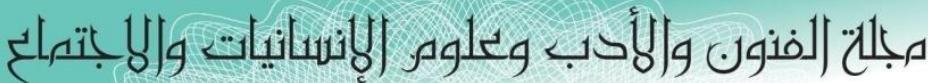
Joumal of Arts, Literature, Humanities and Social Sciences

ISSN online: 2414 - 3383

ISSN print: 2616 - 3810

\section{العدد (42) ايلول - سبتمبر 2019}

جدول (15) اختبار LSD للمقارنات المتعددة لمتغير مستوى تعليم الأب

\begin{tabular}{|c|c|c|c|}
\hline ع عالي = 106.624 & متوسط & من م = & هليم الأب \\
\hline & & - & ض \\
\hline & - & $* * 7.805$ & متوسط \\
\hline- & $* * 16.182$ & $* * 23.987$ & الي \\
\hline
\end{tabular}

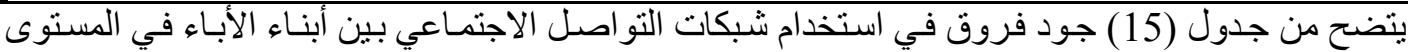

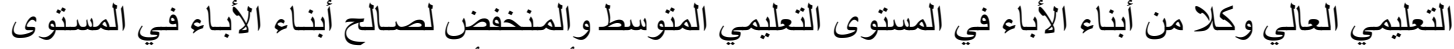

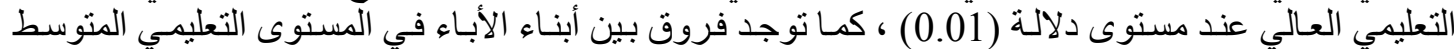

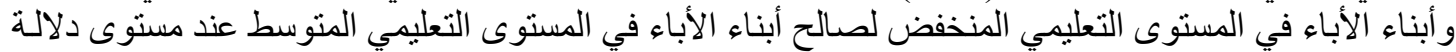

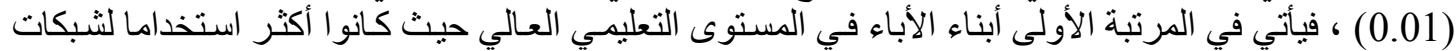

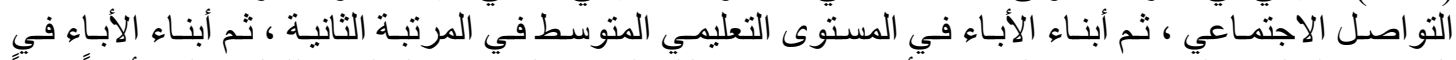

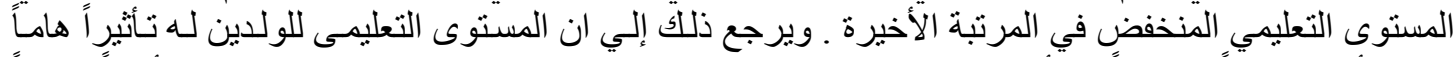

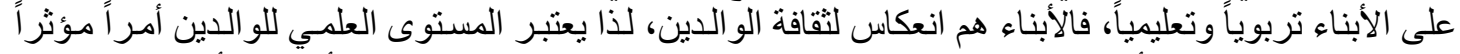

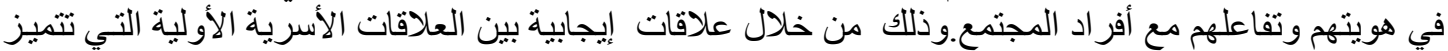

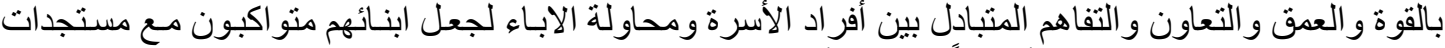

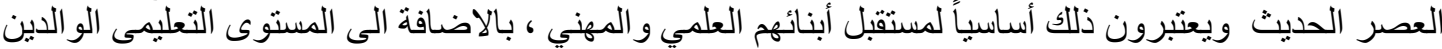

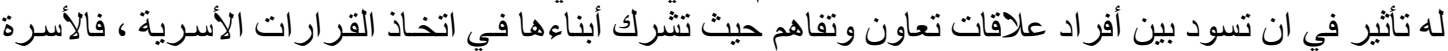

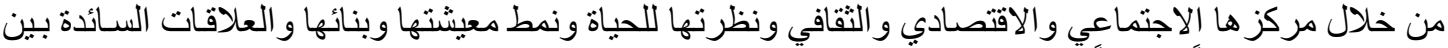

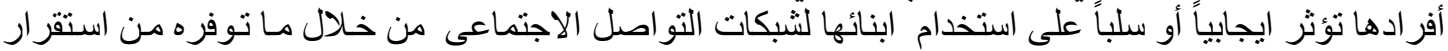

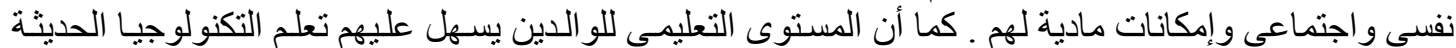
و ادر"الك أهميتها بالنسبة للأبناء.

جدول (16) تحليل التباين لدرجات أفراد العينة في استخدام شبكات التو اصل الاجتماعي تبعا لمتغير تعليم الأم

\begin{tabular}{|c|c|c|c|c|c|}
\hline 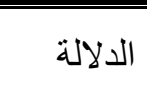 & قيمة (ف) & الحرية & متوسط المربعات & مجموع المربعات & تعليم الأم \\
\hline \multirow{2}{*}{0.01 دال } & \multirow[b]{2}{*}{32.757} & 2 & 3792.246 & 7584.493 & بين المجمو عات \\
\hline & & 317 & 115.769 & 36698.830 & داخل المجمو عات \\
\hline & & 319 & & 44283.323 & المجموع \\
\hline
\end{tabular}

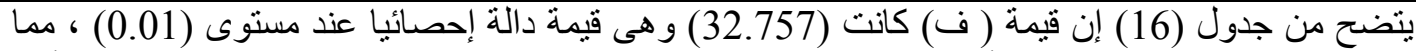

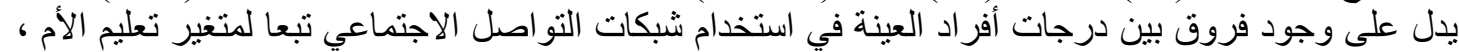

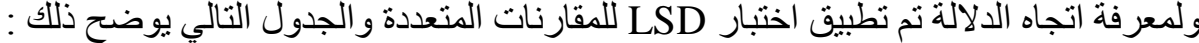

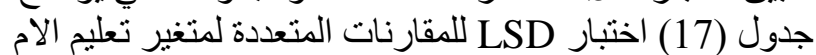

\begin{tabular}{|c|c|c|c|}
\hline مع = عالي 91.830 & متوسط & من = منفض 75.024 & تعليم الأم \\
\hline & & & منخفض \\
\hline & - & $* 2.835$ & متوسط \\
\hline- & $* * 13.971$ & $* * 16.806$ & عالي \\
\hline
\end{tabular}

يتضح من جدول (17) وجود فروق في استخدام شبكات التو اصل الاجتماعي بين أبناء الأمهات في المستوى 


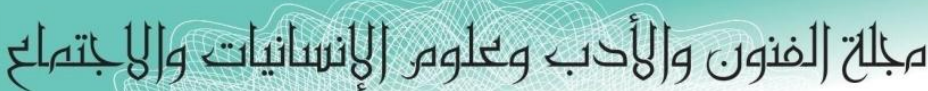

Joumal of Arts, Literature, Humanities and Social Sciences

ISSN online: 2414 - 3383

ISSN print: 2616 - 3810

\section{العدد (42) ايلول - سبتمبر 2019}

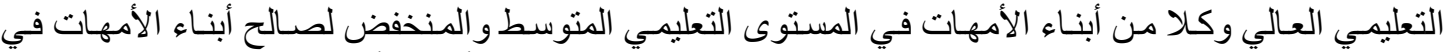

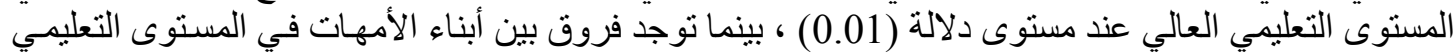

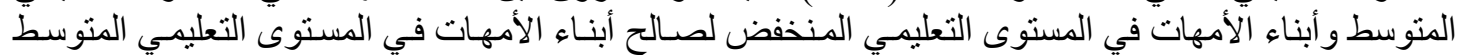

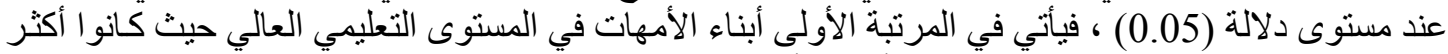

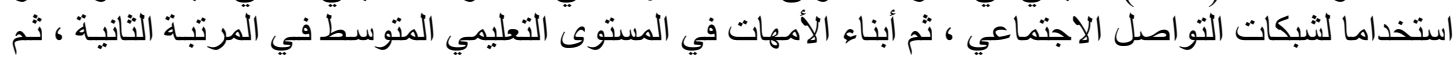

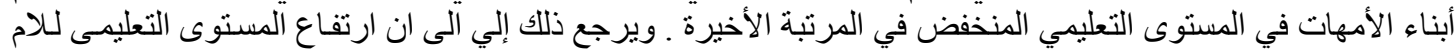

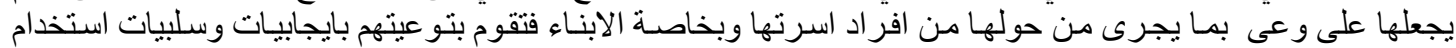

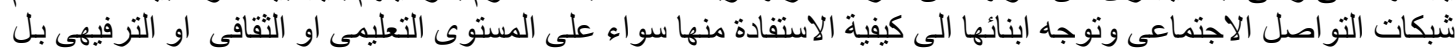

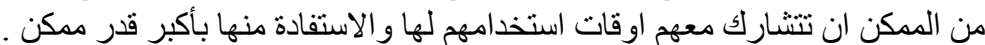

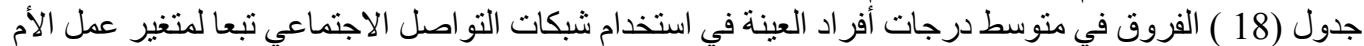

\begin{tabular}{|c|c|c|c|c|c|c|}
\hline الدلالة & قيمة (ت) & الحرية & العينة & الالحياري & الحسابي & عمل الأم \\
\hline \multirow{2}{*}{ لصالح العاملات 0.01 لصال } & \multirow{2}{*}{19.352} & \multirow{2}{*}{318} & 188 & 6.005 & 105.743 & تعمل \\
\hline & & & 132 & 5.823 & 84.631 & لا تعمل \\
\hline
\end{tabular}

يتضح من الجدول (18) أن قيمة ( ت ) كانت (19.352) و هى قيمة دالة إحصائيا عند مستوى دلالآلة (0.01)

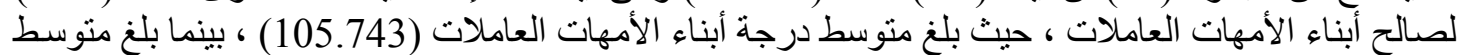

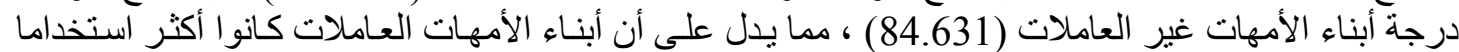

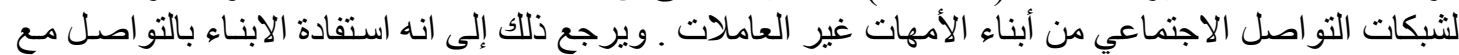

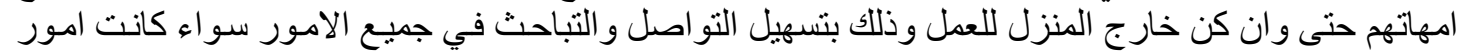

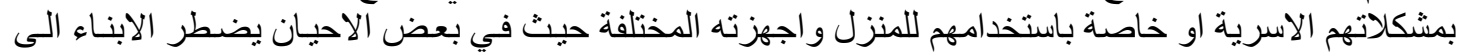

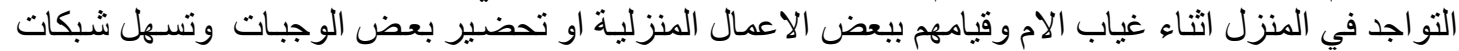

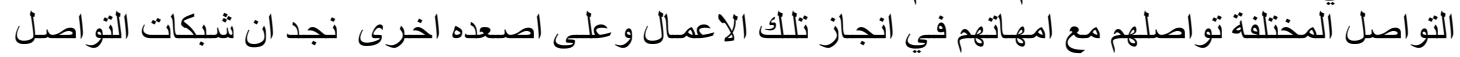

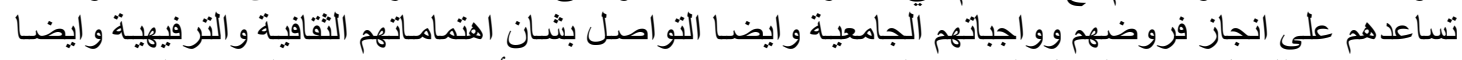

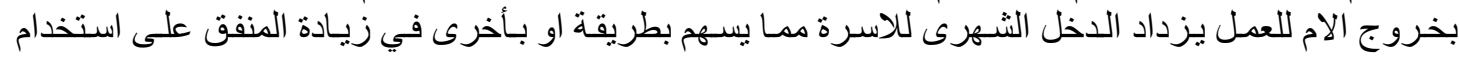

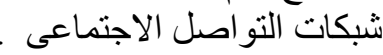

جدول (19) تحليل التباين لدرجات أفراد العينة في استخدام

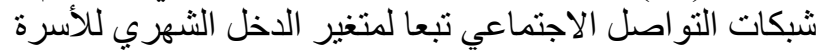

\begin{tabular}{|c|c|c|c|c|c|}
\hline الدلالة الد & قيمة (ف) & درجية & متوسط المربعات & مجموع المربعات & الدخل الشهري للأسرة \\
\hline \multirow{2}{*}{0.01 دال } & \multirow{2}{*}{66.348} & 2 & 4151.176 & 8302.351 & بين المجمو عات \\
\hline & & 317 & 62.567 & 19833.788 & داخل المجمو عات \\
\hline & & 319 & & 28136.139 & المجموع \\
\hline
\end{tabular}

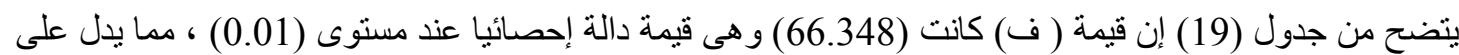

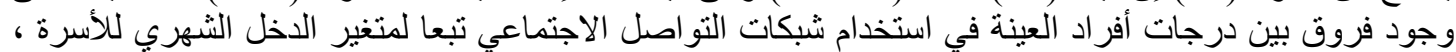
ولمعرفة اتجاه الدلالة نم تطبيق اختبار LSD للمقارنات المتعددة و الجدول التالي يوضي ذبع ذلك : 


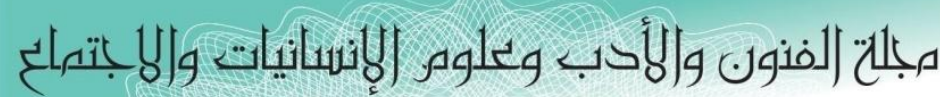
Journal of Arts, Literature, Humanities and Social Sciences

ISSN online: 2414 - 3383

ISSN print: 2616 - 3810

\section{العدد (42) ايلول - سبتمبر 2019}

جدول (20) اختبار LSD للمقارنات المتعددة لمتغير الدخل الثهري للاسرة

\begin{tabular}{|c|c|c|c|}
\hline مرتفع & متوسط = مت 80.806 & من = منفض & خل الثـري للأسرة \\
\hline & & - & خفض \\
\hline & - & $* * 11.696$ & متوسط \\
\hline- & $* * 15.865$ & $* * 27.561$ & رتفع \\
\hline
\end{tabular}

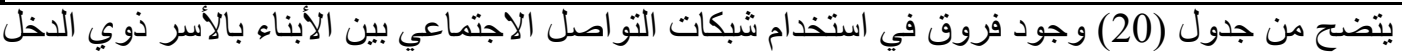

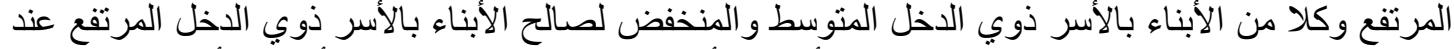

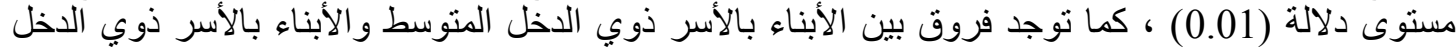

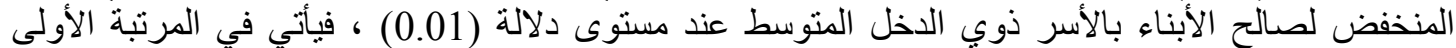

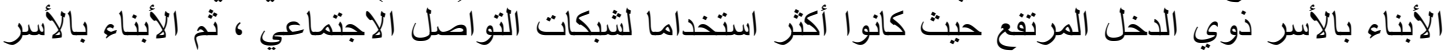

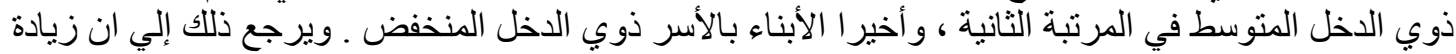

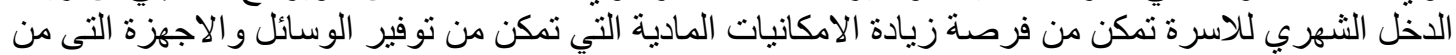

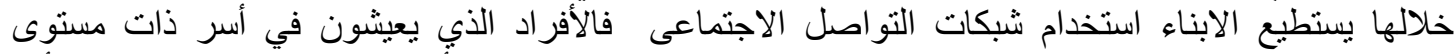

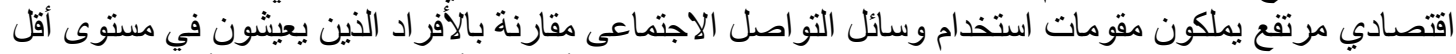

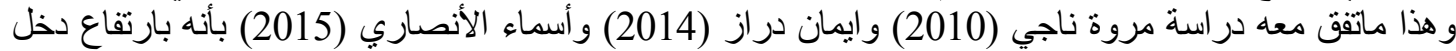
الاسرة يزداد استخدام الأبناء للانترنت ومو اقع التو اصل الاجئ دراعي.ـوبهذا تحقق الفرض الأول

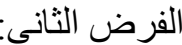
"توجد فروق ذات دلالة إحصائية فى أنماط الحوار السائدة لدى أسر عينة البحث تبعاً لمتغير ات الدراسة (الجنس-

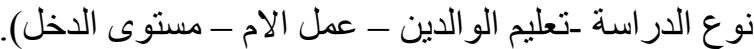

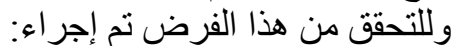

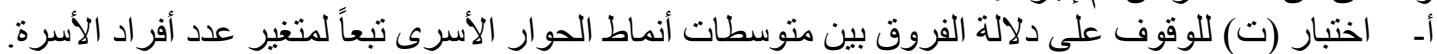

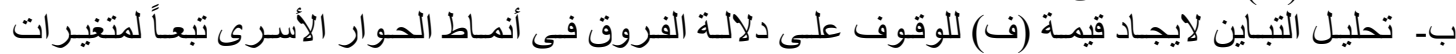
(المستوى التعليمى للأم والأب، الدخل الثهائل الثهري للأسرة).

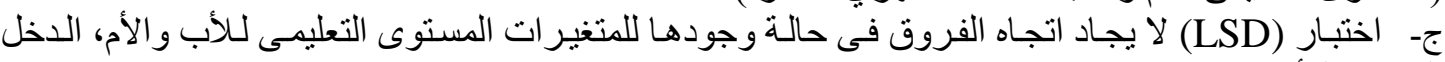

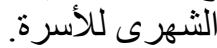
جدول ( 21 ) الفروق في منوسط درجات أفر اد العينة في أنماط الحوار الإيجابية تبعا لمتغير الجنس

\begin{tabular}{|c|c|c|c|c|c|c|c|}
\hline الدلالة & قامة (ت & الحرية & العينة & الالنحراف & الحسابي & الجنس & الأسراط الحوار \\
\hline \multirow{2}{*}{ لدال عند الإناث 0.01} & \multirow{2}{*}{23.514} & \multirow{2}{*}{318} & 144 & 3.845 & $\overline{62.814}$ & ذكور & الحوار \\
\hline & & & 176 & 4.957 & 88.631 & إناث & الايجابي \\
\hline \multirow{2}{*}{ لدال عند الذكور 0.01} & \multirow{2}{*}{20.236} & \multirow{2}{*}{318} & 144 & 7.128 & 73.326 & ذكور & الحوار \\
\hline & & & 176 & 4.059 & 50.501 & إناث & السلبي \\
\hline
\end{tabular}

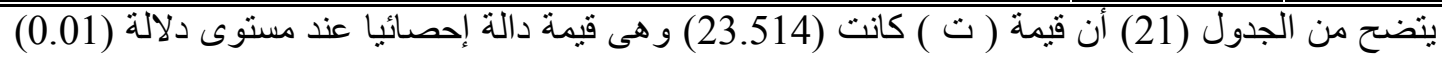

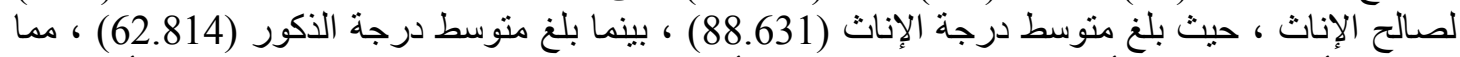

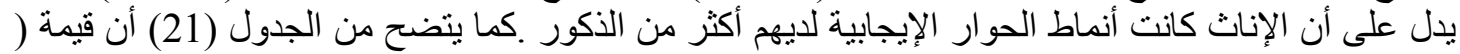

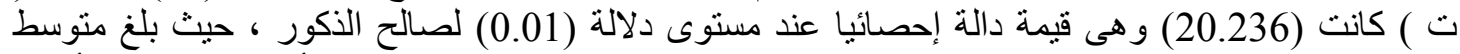

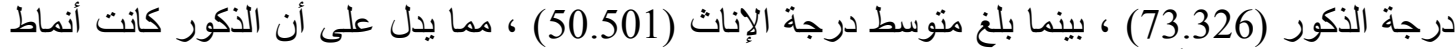

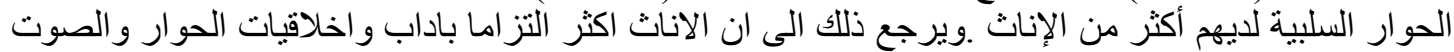




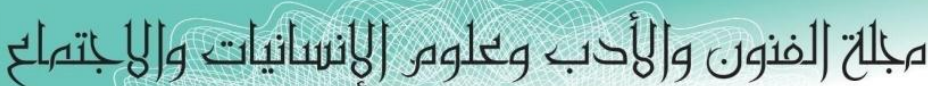
Journal of Arts, Literature, Humanities and Social Sciences

ISSN online: 2414 - 3383

ISSN print: 2616 - 3810

\section{أيلول - سبتهبر 2019}

العدد (42)

LALHSS

www.jalhss.com

المنخفض اما الذكور فيغلب على حوار هم الصوت المرتفع والعصبية والسخرية او استخدام الألفاظ السيئة ، كما

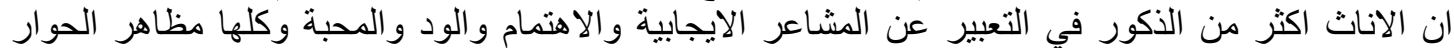
جدولّ (22 ) الفروق في متوسط درجات أفر اد العينة في أنماط الحوار الإيجابية تبعا لمتغير نو ع الدراسة

\begin{tabular}{|c|c|c|c|c|c|c|c|}
\hline الدلالة & قيمة (ت & الحرية & العينة & الالحياري اف & الحسابي & الدرعة & الأسراط الحوار \\
\hline \multirow{2}{*}{ لصالح عملية 0.01} & \multirow{2}{*}{25.415} & \multirow{2}{*}{318} & 204 & 3.097 & 54.669 & نظرية & \multirow{2}{*}{ الحوار الايجابي } \\
\hline & & & 116 & 4.081 & 81.067 & عملية & \\
\hline \multirow{2}{*}{ دال عند 0.01} & 15.783 & 318 & 204 & 6.752 & 68.811 & نظرية & \multirow[t]{2}{*}{ الحوار السلبي } \\
\hline & & & 116 & 4.120 & 52.025 & عملية & \\
\hline
\end{tabular}

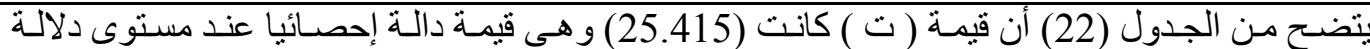

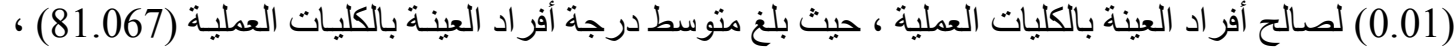

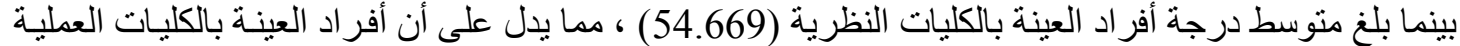

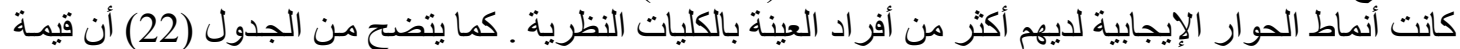

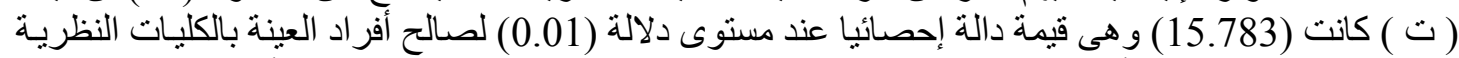

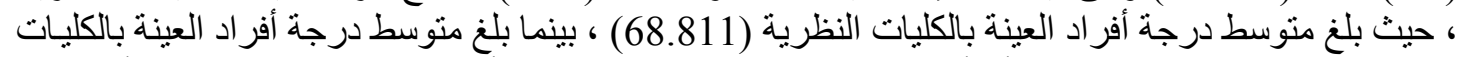

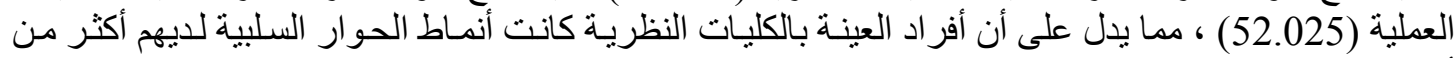
أفر اد العينة بالكليات العملية . جدول (23 ) تحليل التباين لدرجات أفر اد العينة في أنماط الحوار الإيجابية تبعا لمتغير تعليم الأب

\begin{tabular}{|c|c|c|c|c|c|c|}
\hline الدلالة & فيمة ( فيمة & الحرية & المربعات & مجموع المربعات & تعليم الأب & الانماط \\
\hline \multirow{3}{*}{$\begin{array}{c}0.01 \\
\text { دال }\end{array}$} & \multirow{2}{*}{42.520} & 2 & 3931.523 & 7863.046 & بين المجمو عات & \multirow{3}{*}{ الايجابي } \\
\hline & & 317 & 92.463 & 29310.883 & داخل المجمو عات & \\
\hline & & 319 & & 37173.929 & المجموع & \\
\hline \multirow{3}{*}{$\begin{array}{r}0.01 \\
\text { دال }\end{array}$} & \multirow{2}{*}{39.462} & 2 & 3892.479 & 7784.957 & بين المجمو عات & \multirow{3}{*}{ السليدار } \\
\hline & & 317 & 98.639 & 31268.550 & داخل المجمو عات & \\
\hline & & 319 & & 39053.507 & المجموع & \\
\hline
\end{tabular}

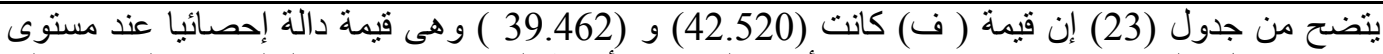

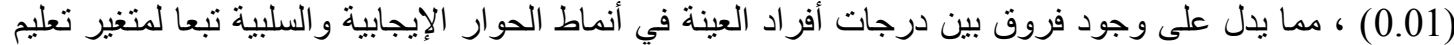

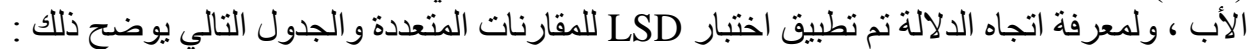

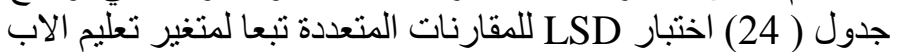

\begin{tabular}{|c|c|c|c|c|}
\hline ع عالي 85.058 مالم & مت = مسط 73.146 م3.14 & من = منفض 66.618 & تعليم الأب & الأسراط الحوار \\
\hline & & & منخفض & \multirow[t]{3}{*}{ الحوار الايجابي } \\
\hline & - & **6.528 & متوسط & \\
\hline - & $* * 11.912$ & $* * 18.440$ & عالي & \\
\hline
\end{tabular}




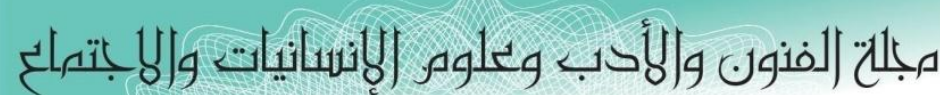

Journal of Arts, Literature, Humanities and Social Sciences

ISSN online: 2414 - 3383

ISSN print: 2616 - 3810

العدد (42) أيلول - سبتمبر 2019

\begin{tabular}{|c|c|c|c|c|}
\hline ع عالي $\begin{aligned} & \text { ع } \\
& 49.024\end{aligned}$ & متوسط $\begin{array}{c}\text { مت } 51.325 \\
51.35\end{array}$ & من = منفض 65.381 & تعليم الاب & \\
\hline & & & منخفض & \multirow[t]{3}{*}{ لحوار السلبي } \\
\hline & - & **14.056 & متوسط & \\
\hline & *2.301 & **16.357 & عالي & \\
\hline
\end{tabular}

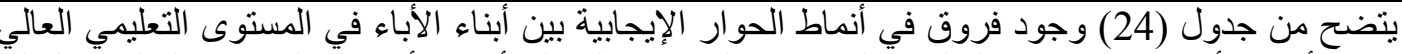

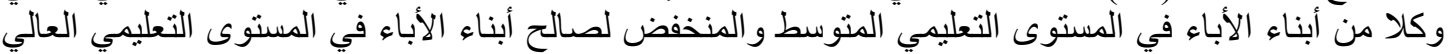

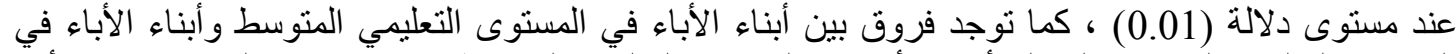

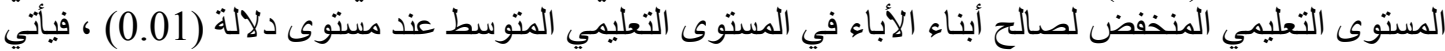

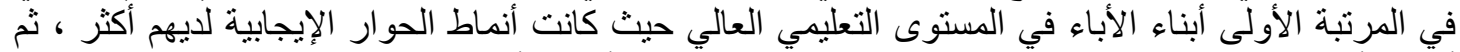

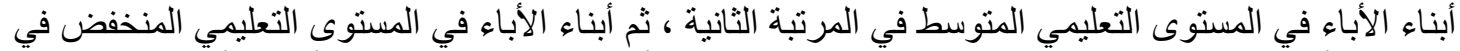

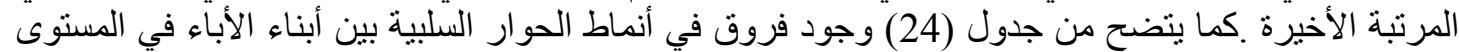

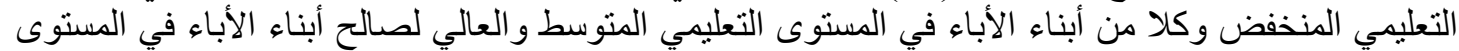

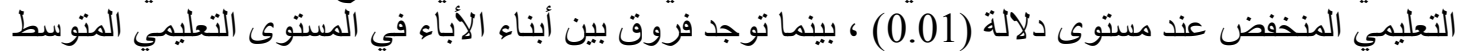

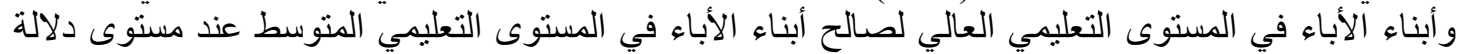

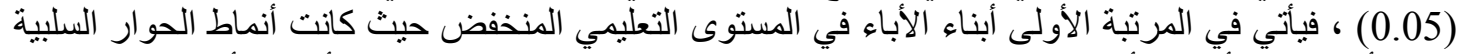

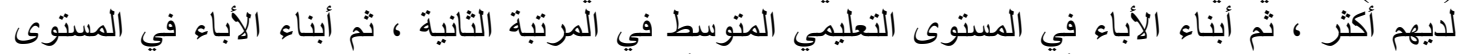

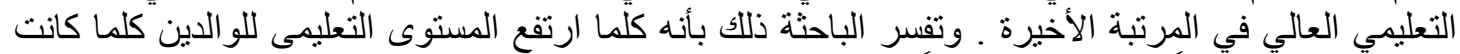

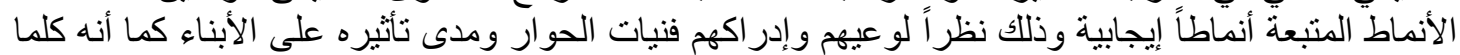

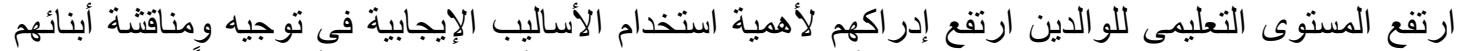

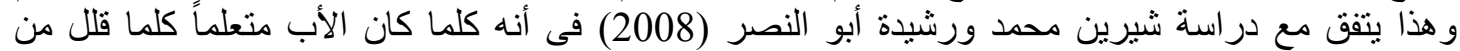

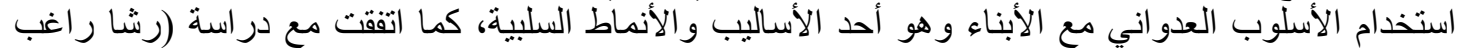

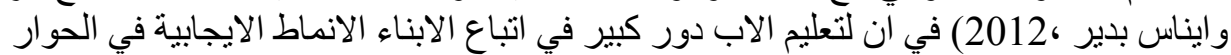

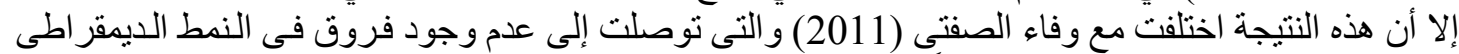
و النمط الدكتانورى المتبع فى الأسرة وفقاء للمستوى التعليمى للو الدئ الدين.

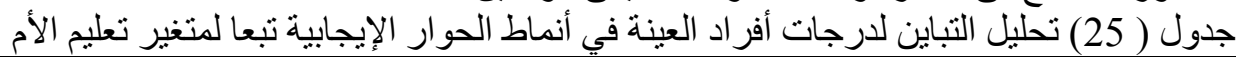

\begin{tabular}{|c|c|c|c|c|c|c|}
\hline الدلالة & فيمة ( فيمة & الحرية & المربعات & المربعوع & ت تعليم الأم & الانماط \\
\hline \multirow{3}{*}{$\begin{array}{r}0.01 \\
\text { دال }\end{array}$} & \multirow{2}{*}{53.100} & 2 & 4043.985 & 8087.970 & بين المجمو عات & \multirow{3}{*}{ الايجابي } \\
\hline & & 317 & 76.158 & 24142.067 & داخل المجمو عات & \\
\hline & & 319 & & 32230.037 & المجموع & \\
\hline \multirow{3}{*}{$\begin{array}{r}0.01 \\
\text { دال }\end{array}$} & \multirow{2}{*}{60.119} & 2 & 24104.399 & 8208.798 & بين المجمو عات & \multirow{3}{*}{ الحئرار } \\
\hline & & 317 & 68.271 & 21642.033 & داخل المجمو عات & \\
\hline & & 319 & & 29850.831 & المجموع & \\
\hline
\end{tabular}

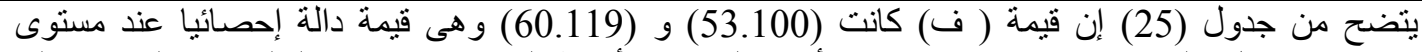

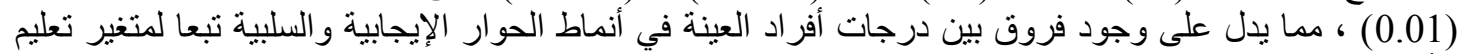

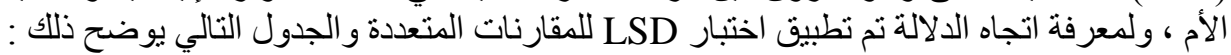




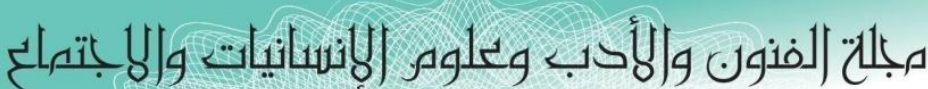
Joumal of Arts, Literature, Humanities and Social Sciences

ISSN online: 2414 - 3383

ISSN print: 2616 - 3810 أيلول - سبتمبر 2019

العدد (42)

جدول ( 26 ) اختبار LSD للمقارنات المتعددة لمتغير تعليم الأم

\begin{tabular}{|c|c|c|c|c|}
\hline مالي & مت = متوسط & منخفض = & تعليم الأم & الأسري الحوار \\
\hline & & & منخفض & الحوار \\
\hline & - & $* * 6.903$ & متوسط & الايجابي \\
\hline- & $* * 18.396$ & $* * 25.299$ & عالي & \\
\hline ع عالي & متوسط & منخفض = & تعليم الأم & \\
\hline & & - & منخفض & الحوار \\
\hline & - & $* * 9.485$ & متوسط & السلبي \\
\hline- & $* * 12.178$ & $* * 21.663$ & عالي & \\
\hline
\end{tabular}

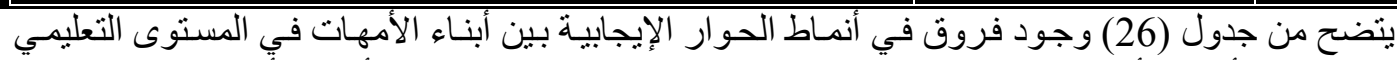

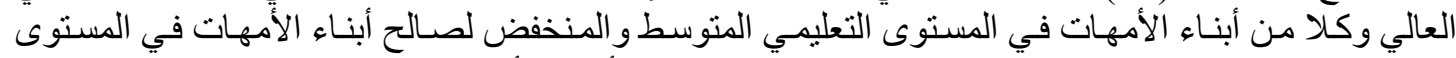
التعليمي العالي عند مستوى دلالة (0.01) ، كما توجد فروق بين أبناء الأمهات في المستوى التعليمسي المتوسط التهاء

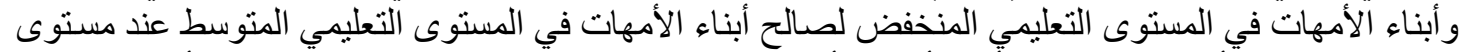

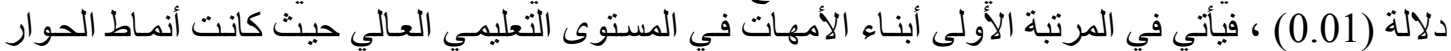

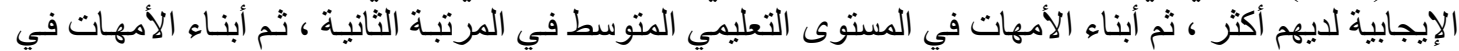

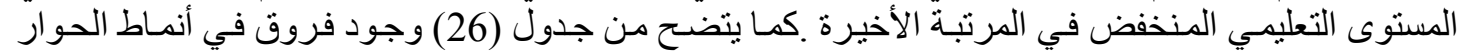

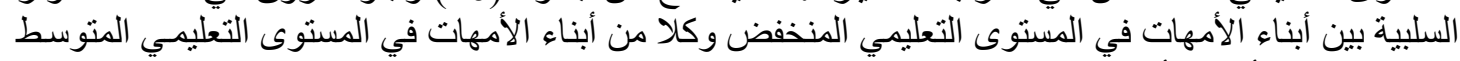

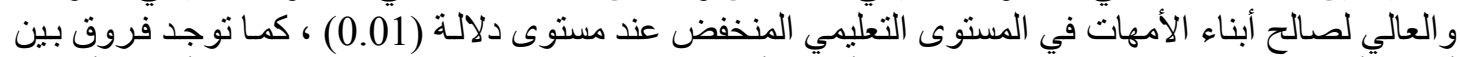

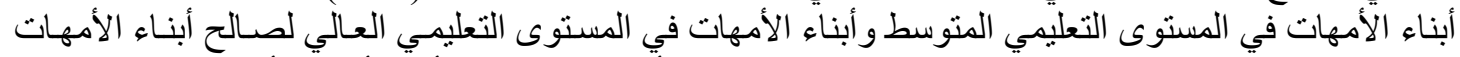

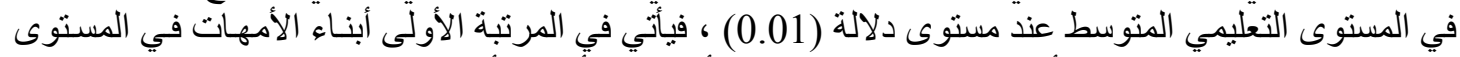

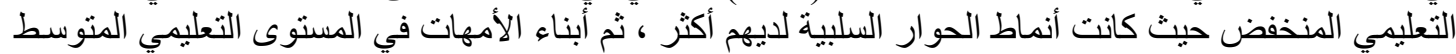

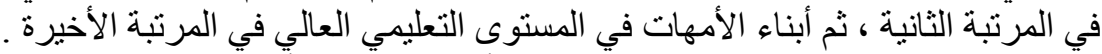

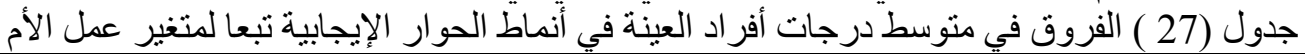

\begin{tabular}{|c|c|c|c|c|c|c|c|}
\hline الدلالة & قيمة ( ت ) & الحرية & العينة & الانحر افياري & المستوسطي & عمل الأح & الاسري الحوار \\
\hline \multirow{2}{*}{ لصال عند العاملات 0.01} & \multirow{2}{*}{21.027} & \multirow{2}{*}{318} & 188 & 5.814 & 86.444 & تعمل & الحوار \\
\hline & & & 132 & 4.004 & 63.153 & لا تعمل & \\
\hline \multirow{2}{*}{ لصالح عند 0.01 لصير العاملات } & \multirow{2}{*}{11.162} & \multirow{2}{*}{318} & 188 & 4.211 & 47.712 & تعمل & الحوار \\
\hline & & & 132 & 5.870 & 60.603 & لا تعمل & \\
\hline
\end{tabular}

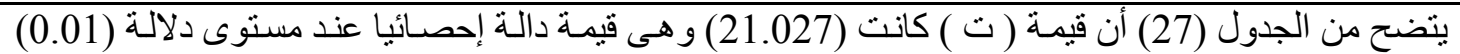

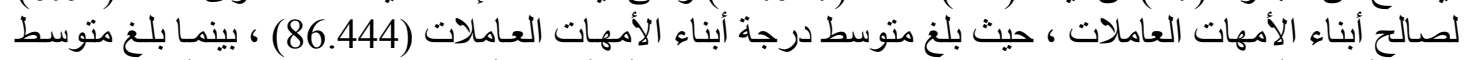

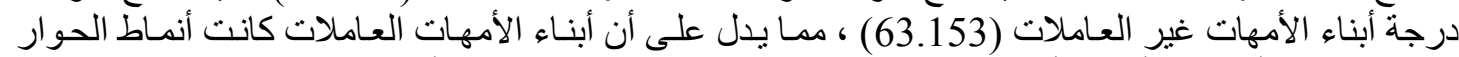

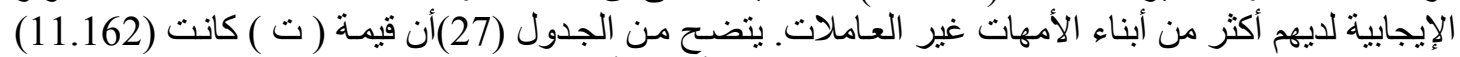

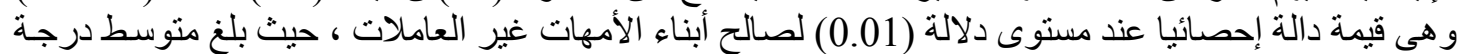

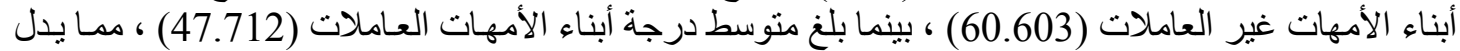

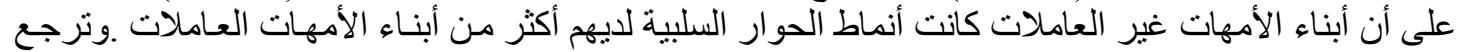

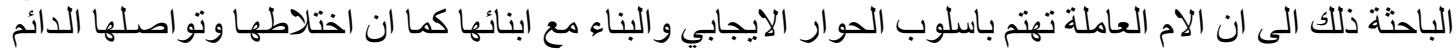


مجلحت (لفنون والأذب وعلوهر الإنسانيات و|له بتماتع Journal of Arts, Literature, Humanities and Social Sciences

ISSN online: 2414 - 3383

ISSN print: 2616 - 3810

\section{العدد (42) أيلول - سبتمبر 2019}

LALHSS

WWw.jalhss.com

مع الاخرين في عملها اكسبها الاساليب الجيدة والايجابية في الحوار وطرق التواصل السليم و الذي يبني شخصية

ابنائها.

جدول (28) تحليل التباين لدرجات أفر اد العينة في أنماط الحوار الإيجابية تبعا لمتغير الدخل الثهري للأسرة

\begin{tabular}{|c|c|c|c|c|c|c|}
\hline الدلالة & فتيمة ( & الحرية & متوسط & المربعات & للأسرة الثهري & الأسراط الحوار \\
\hline \multirow{3}{*}{$\begin{array}{r}0.01 \\
\text { دال }\end{array}$} & \multirow{2}{*}{36.126} & 2 & 3845.445 & 7690.890 & بين المجمو عات & \multirow{3}{*}{ الايجابي } \\
\hline & & 317 & 106.444 & 33742.885 & داخل المجمو عات & \\
\hline & & 319 & & 41433.775 & المجموع & \\
\hline \multirow{3}{*}{$\begin{array}{r}0.01 \\
\text { دال }\end{array}$} & \multirow{2}{*}{46.988} & 2 & 3982.797 & 7965.594 & بين المجمو عات & \multirow[t]{3}{*}{ الحوار السلبي } \\
\hline & & 317 & 84.761 & 26869.271 & داخل المجمو عات & \\
\hline & & 319 & & 34834.865 & المجموع & \\
\hline
\end{tabular}

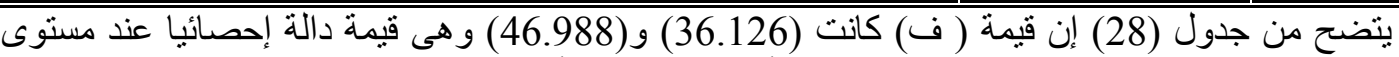

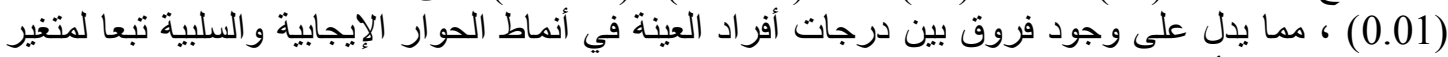

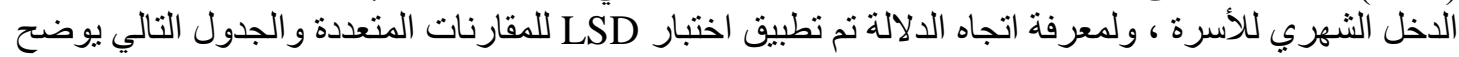

جدول (29) اختبار LSD للمقارنات المتعددة بعا لمتغير الدخل الثهري

\begin{tabular}{|c|c|c|c|c|}
\hline مرتفع 83.360 مرتف & متوسط = من 70.442 & منخفض = 68.024 & الدخل الشهري للأسرة & انماط الحوار \\
\hline & & - & منخفض & \multirow[t]{3}{*}{ الحوار اليجابي } \\
\hline & - & $* 2.418$ & متوسط & \\
\hline- & $* * 12.918$ & $* * 15.336$ & مرتفع & \\
\hline \multirow[t]{4}{*}{ مرتفع } & متوسط = مت 57.736 & من =خفض 72.271 & الدخل الثهري للأسرة & \multirow{4}{*}{ الحوار السلبي } \\
\hline & & & منخفض & \\
\hline & - & $* * 14.535$ & متوسط & \\
\hline & $* * 11.416$ & $* * 25.951$ & مرتفع & \\
\hline
\end{tabular}

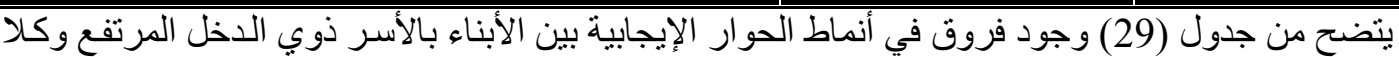

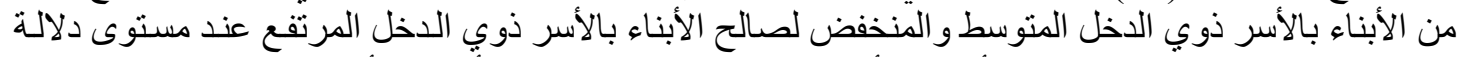

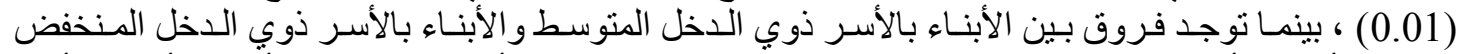

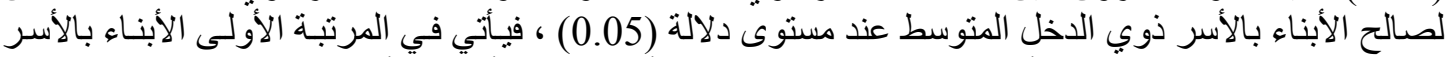

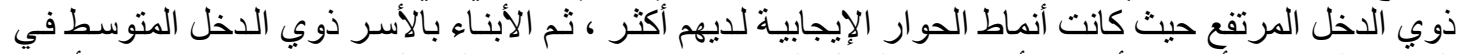

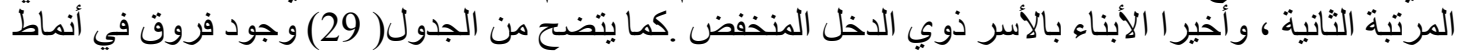

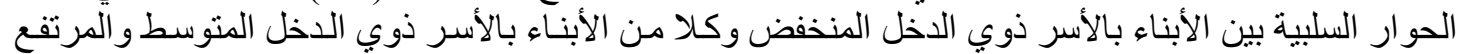

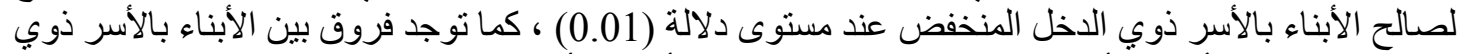

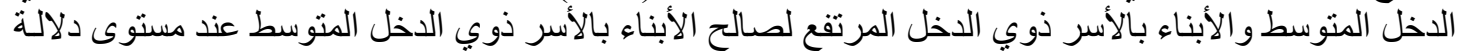

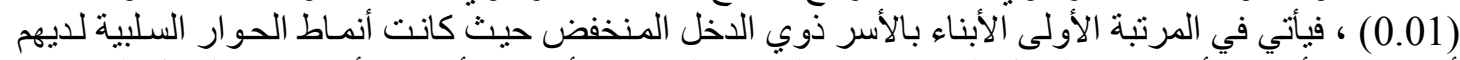

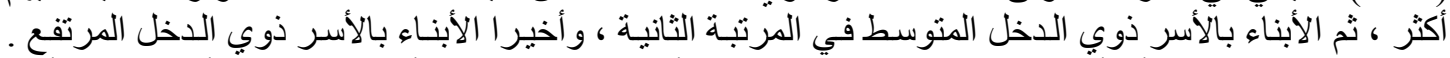

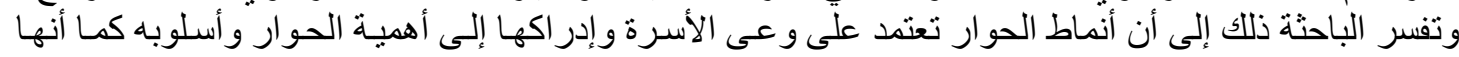


مجلحت (لفنون والأذب وعلوهر الإنسانيات و|له بتماتع

Joumal of Arts, Literature, Humanities and Social Sciences

ISSN online: 2414 - 3383

ISSN print: 2616 - 3810

\section{العدد (42) ايلول - سبتمبر 2019}

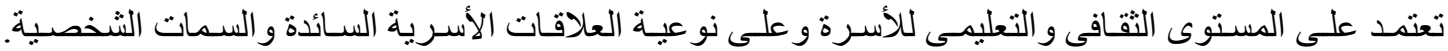

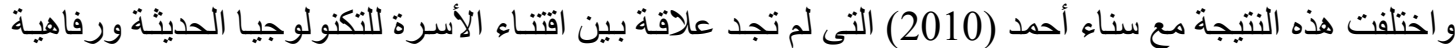

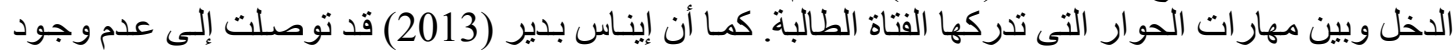

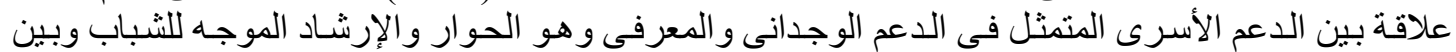

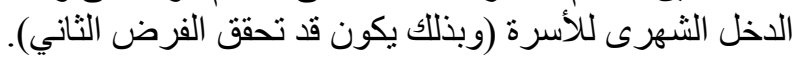

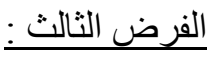

" توجد علاقة ارتباطية ذات دلال احصائية بين استخدام شبكات التواصل الاجتماعي ومحاور مقياس أنماط

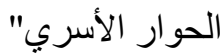

وللتحقق من صحة هذا الفرض تم عمل مصفوفة ارتباط بين مقياس استخدام شبكات التو اصل الاجتماعي

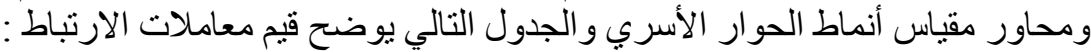

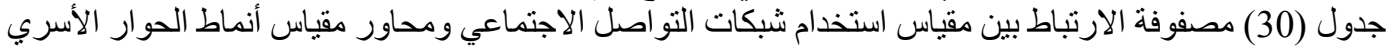

\begin{tabular}{|c|c|c|c|c|c|c|c|}
\hline ألأسراط الحوار & أنماط الحوار & التسلطي & الحدواني & الإنماط الحوابية ككل & العاطفي & والحوار & \\
\hline$* * 0.835$ & $* * 0.898$ & $* 0.641$ & $* * 0.929$ & $* * 0.749$ & $* * 0.905$ & *0.618- & التو اصندل شبكل الاجنماعي \\
\hline
\end{tabular}

0.05 (

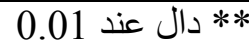

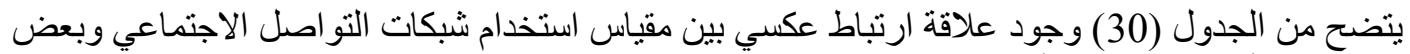

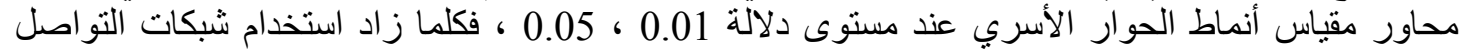

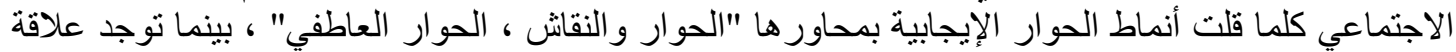

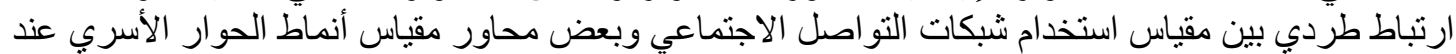

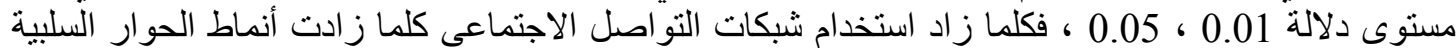

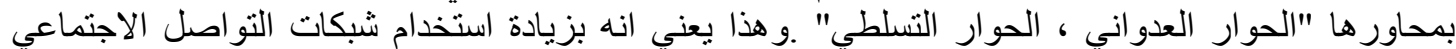

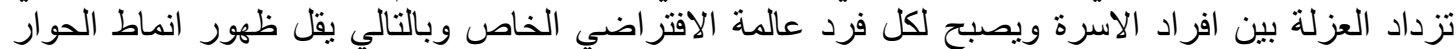

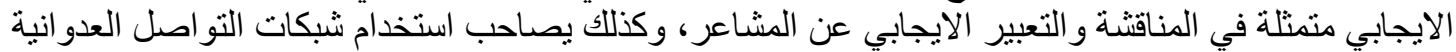

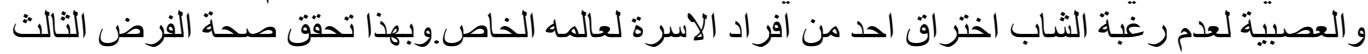

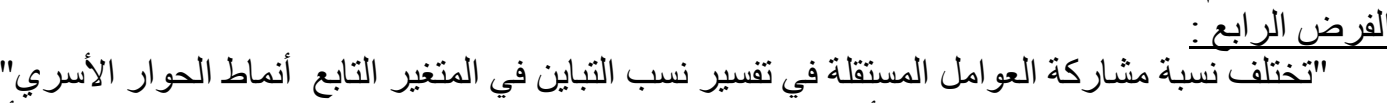

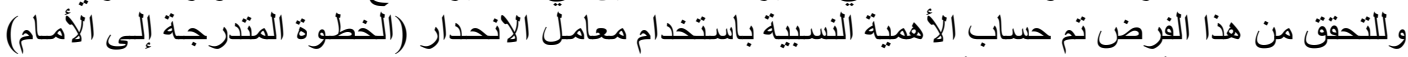
للعو امل المؤثرة على أنماط الحوار الأسري و الجدول التالي يوضح ذللك :

جدول (31 ) الأهمية النسبية باستخدام معامل الانحدار (الخطوة المندرجة إلى الأمام) للعو امل المؤثرة على أنماط

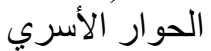

\begin{tabular}{|c|c|c|c|c|c|c|c|c|}
\hline 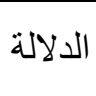 & قيمة (ت) & معامل & 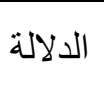 & قيمة( ف) & المشبار كة & الارتباط & المتغير المستقل & \\
\hline 0.01 & 10.340 & 0.506 & 0.01 & 106.911 & 0.792 & 0.890 & تعليم الأم & \\
\hline 0.01 & 7.866 & 0.362 & 0.01 & 61.869 & 0.688 & 0.831 & تعليم الأب & $k$ \\
\hline 0.01 & 6.830 & 0.283 & 0.01 & 46.647 & 0.625 & 0.791 & عمل الأم & 5 \\
\hline 0.01 & 6.140 & 0.225 & 0.01 & 37.702 & 0.574 & 0.758 & استخدام شبكات التو اصل & \\
\hline
\end{tabular}




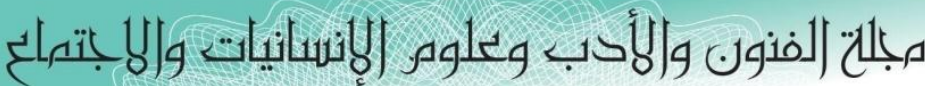

Journal of Arts, Literature, Humanities and Social Sciences

ISSN online: 2414 - 3383

ISSN print: 2616 - 3810

\section{العدد (42) أيلول - سبتمبر 2019}

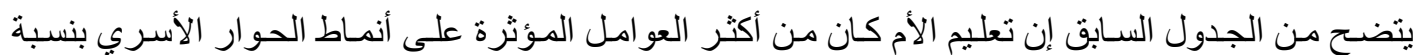

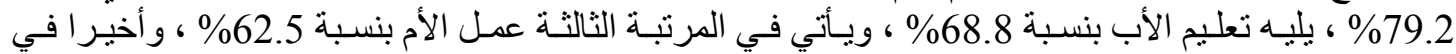

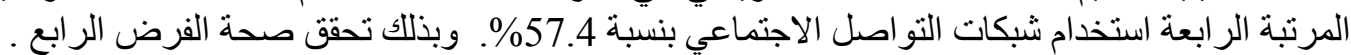

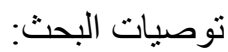

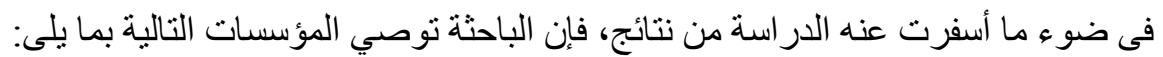

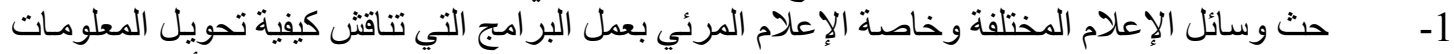

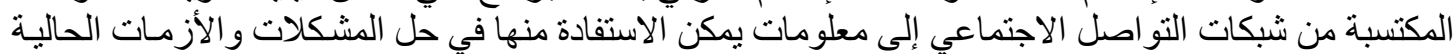
و المستقبلية للابناء.

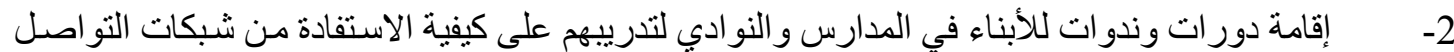

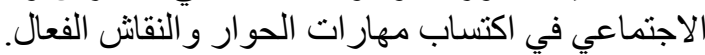

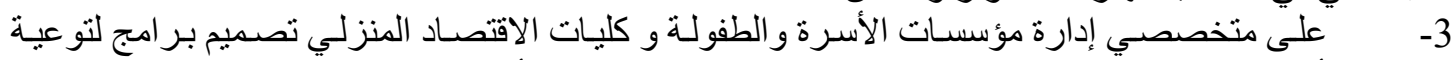

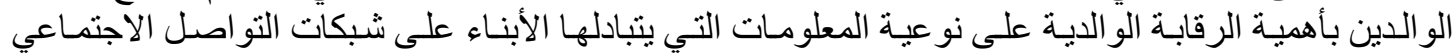
و ادارة الحوار و النقاش الفعال معهر.

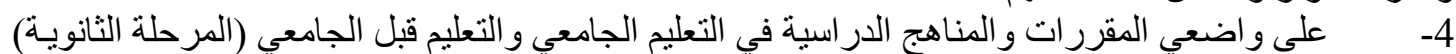

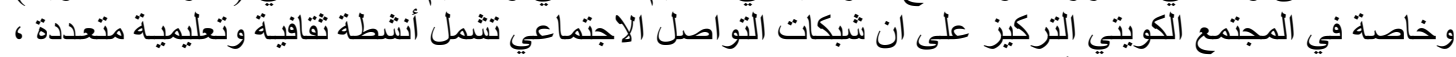

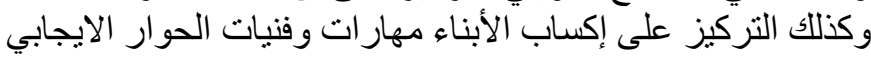

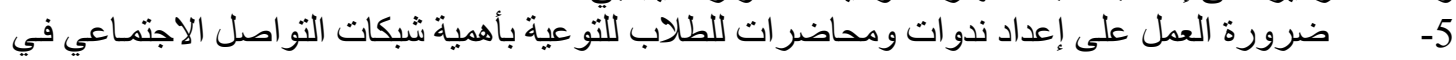

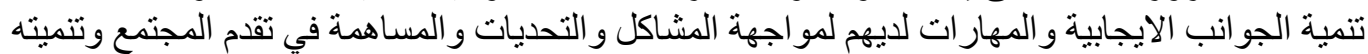

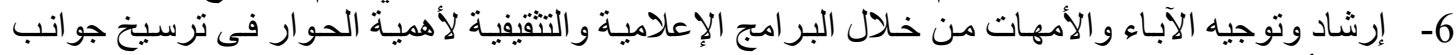

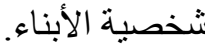

7- عقد دورات تدريبية للقائمين على الأطر الطلابية بالجامعات لتتمية ثقافة الحوار لما لها من دور في تثكيل

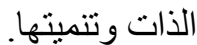
8- التوعية الأسرية وذلك من خلال أهمية توفير البيئة الملائمة لنمو الأفر اد و إعطاء سعة للنقاش و الحوار لما

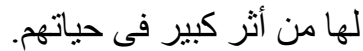

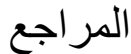

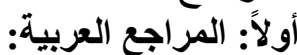

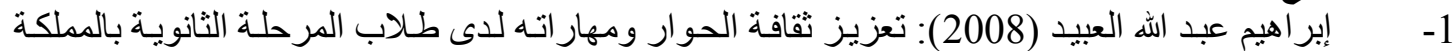

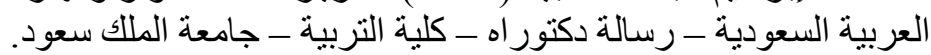

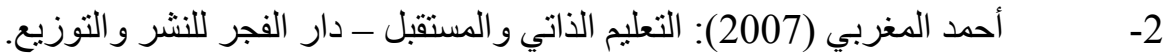

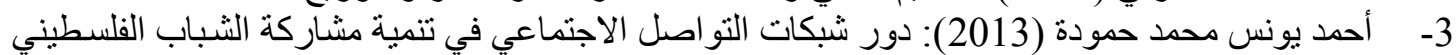

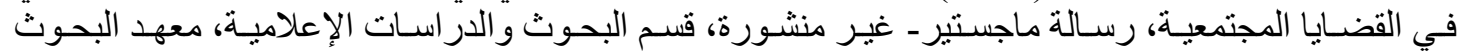

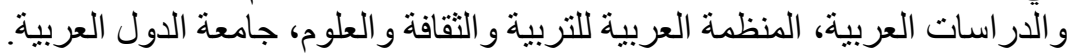

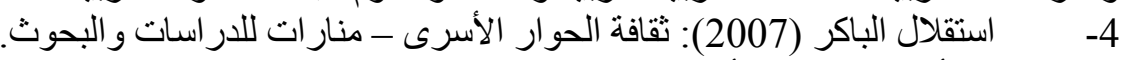

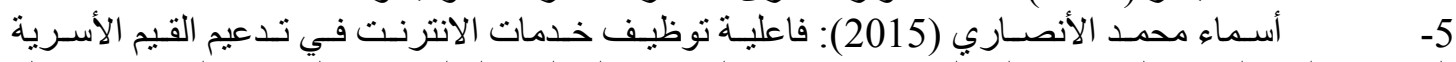

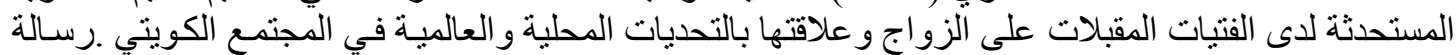

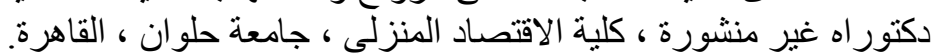

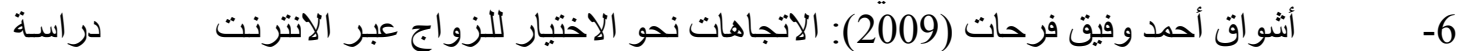

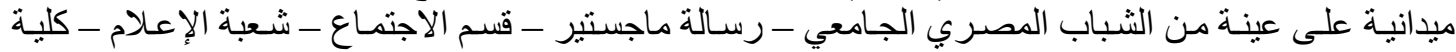
البنات للآداب و العلوم النربوية - جامعة عبن شمس. 7-

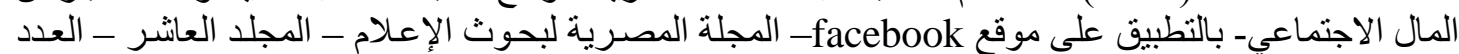
الر ابع - كلية الإعلام - ديسمبر 2012. 


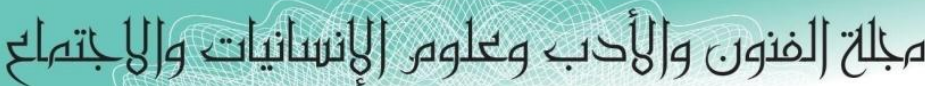

Journal of Arts, Literature, Humanities and Social Sciences

ISSN online: 2414 - 3383

ISSN print: 2616 - 3810

\section{العدد (42) ايلول -سبتمبر 2019}

8- أمانى عبد المقصود عبد الوهاب (2007): أثر المساندة الوالديـة على الثـعور بالرضـا عن الحيـاة للدى

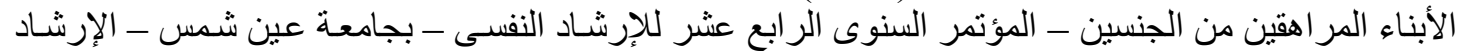

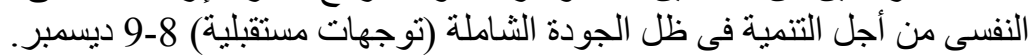

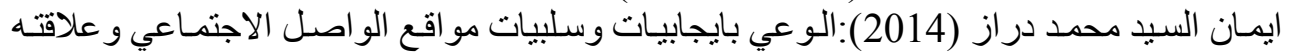

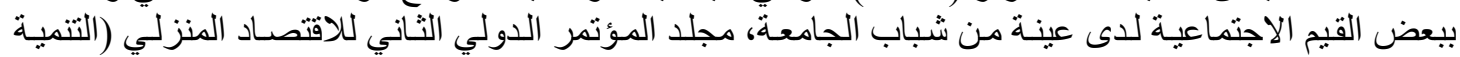

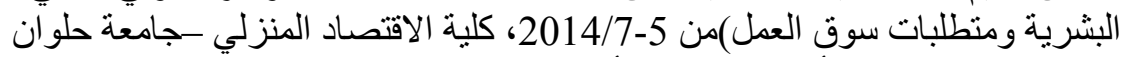

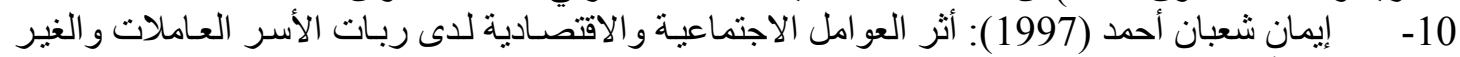

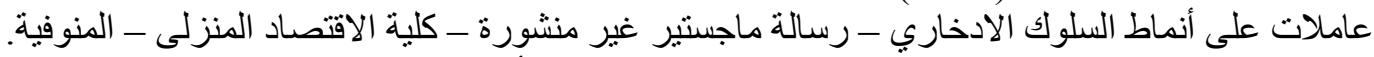

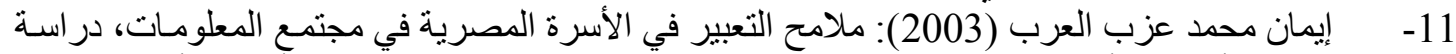

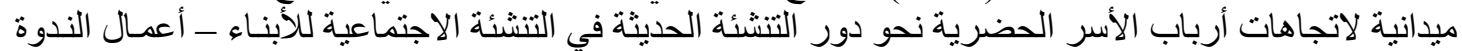

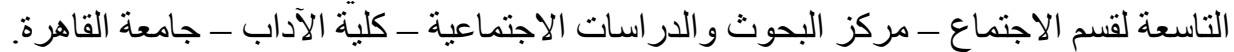

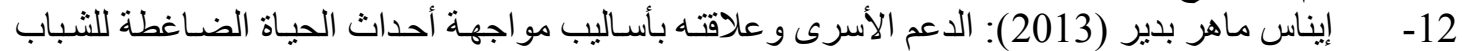

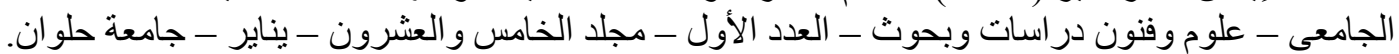
13- توفيق التويجري (2009): الفيس بوك و الاتجاهـات السلوكية، مجلة الصحة النفسيةـ عدد (8) جامعـة القاهرة.

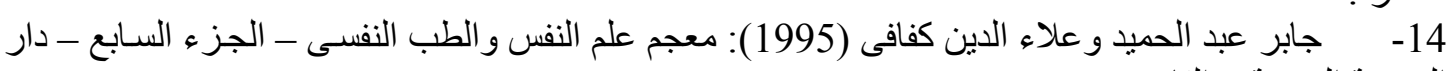
النهضة العربية - القاهرة.

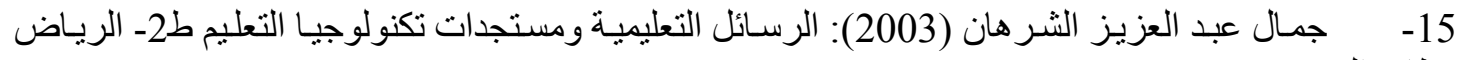
16- مطابع الحميضي.

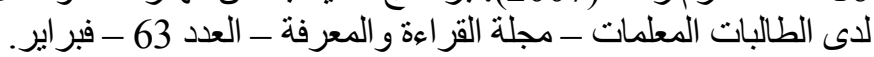

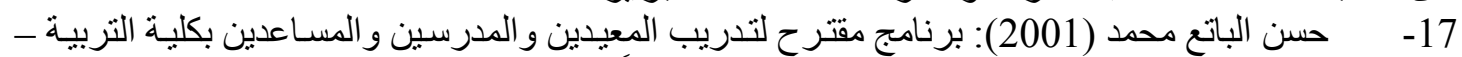

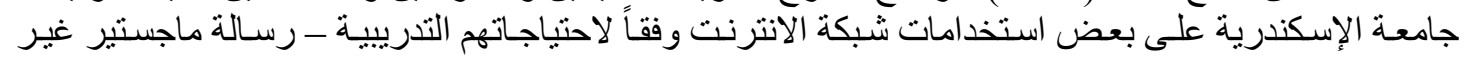
منشورة - كلبة التربية - جامعة الإسكندرية.

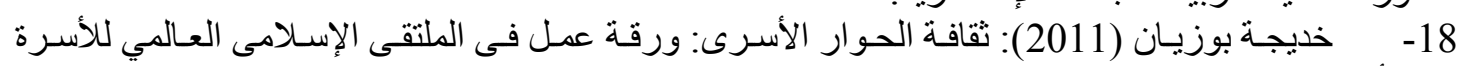

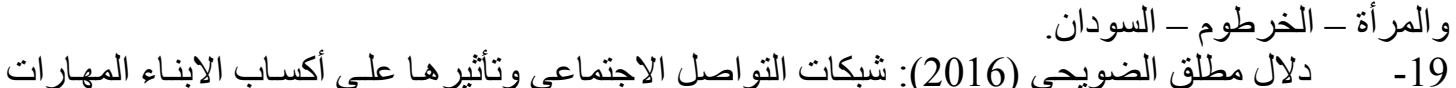

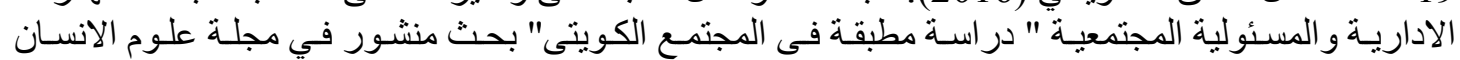

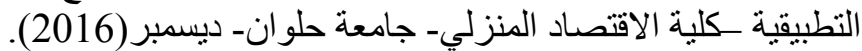

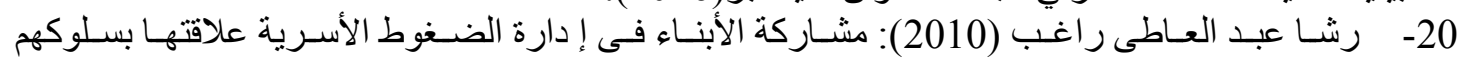

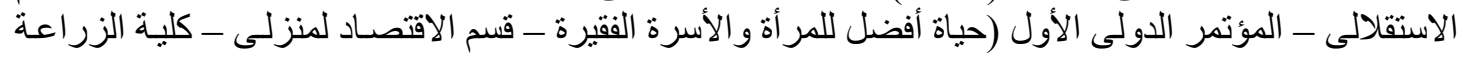

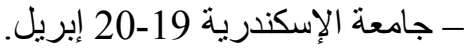

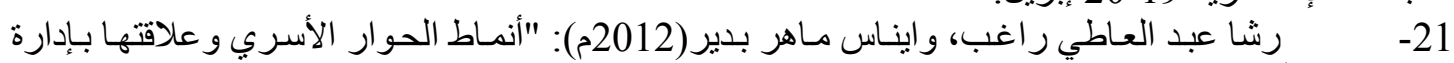

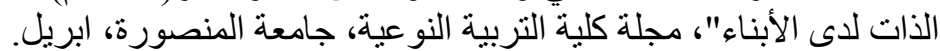

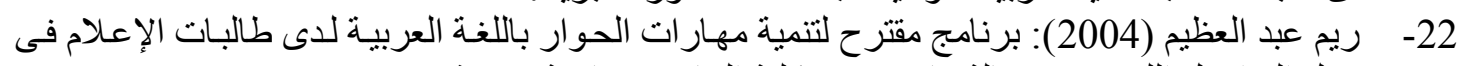

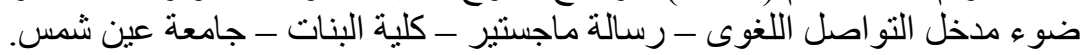

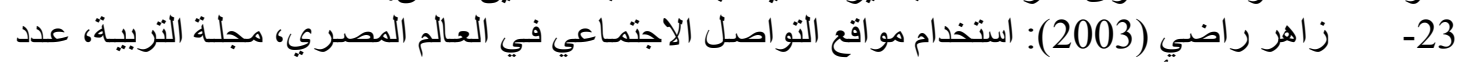
(15)، جامعة عمان الأهلية - عمان.

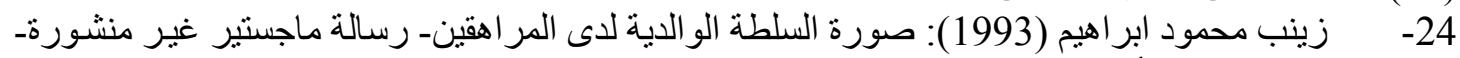
قسم علم النفس - كلية الأداب- جامعة عين (19) شئ شمس.

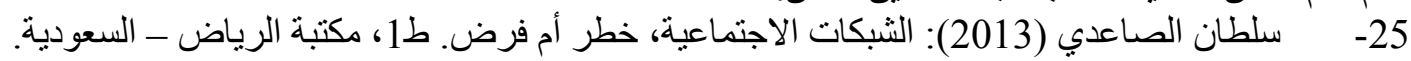

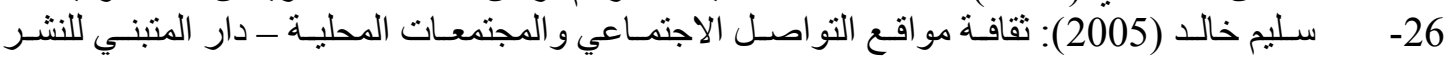




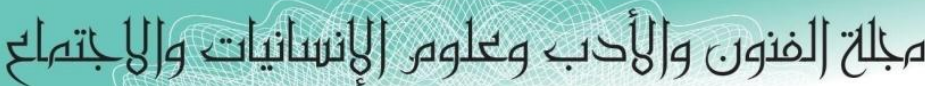

Journal of Arts, Literature, Humanities and Social Sciences

ISSN online: 2414 - 3383

ISSN print: 2616 - 3810

\section{العدد (42) ايلول - سبتمبر 2019}

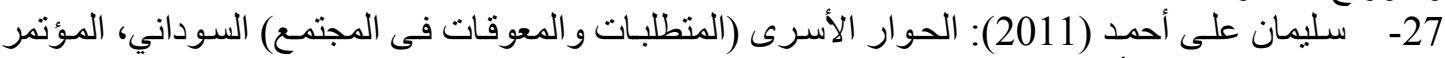

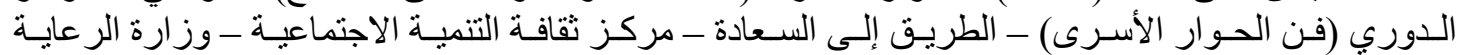

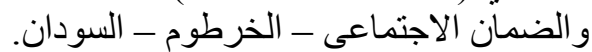

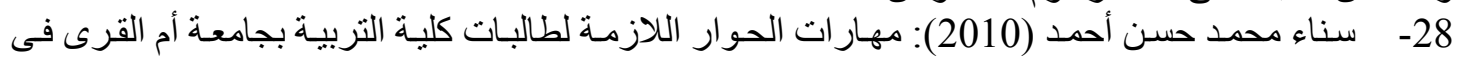

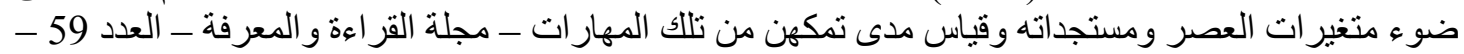
يناير - معهد البحوث التربوية - جامعة القاهرة.

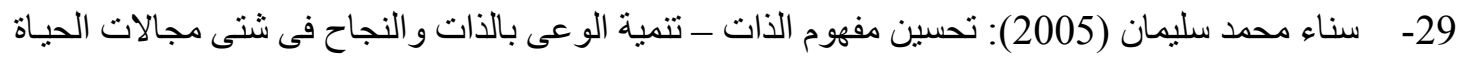

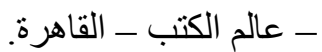
30- سيد الهو اري (1996): ملامح مدير المستقبل - مكتبة عين شمس - القاهرة.

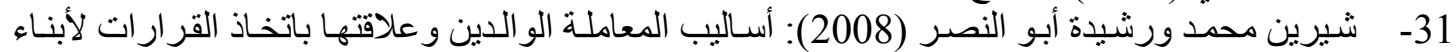

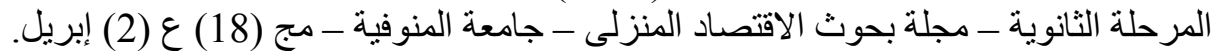

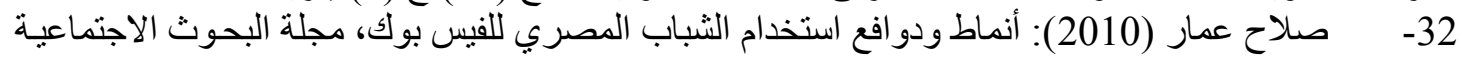
- جامعة القاهرة، عدد 22 مصر .

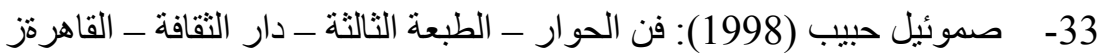

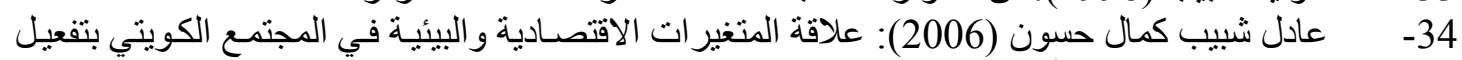

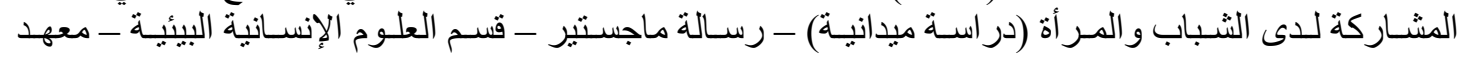
الدراسات و البحوث البيئية - جامعة عين شمس.

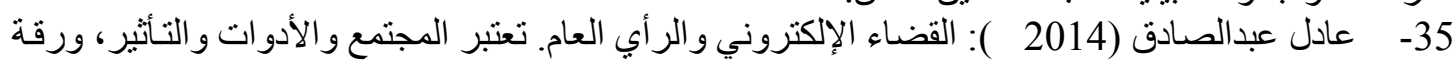

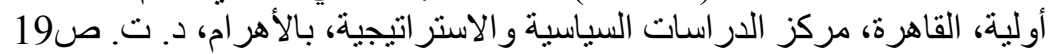

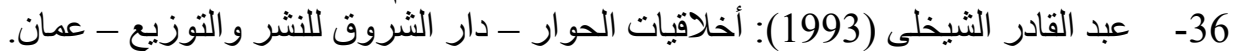

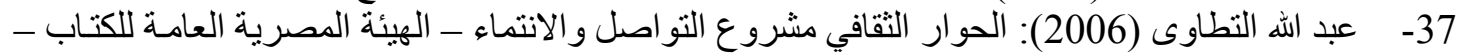

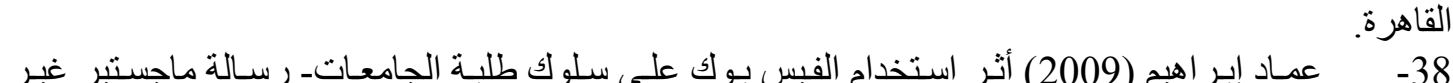

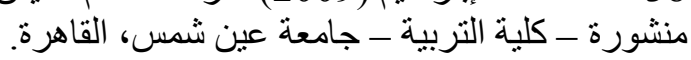

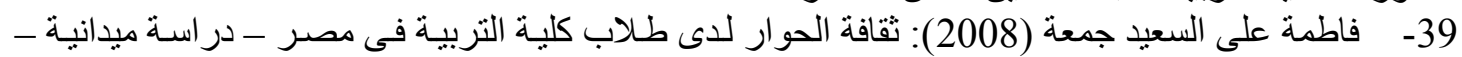

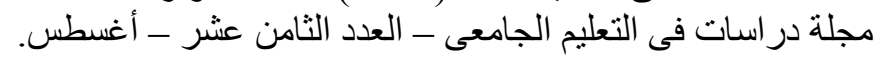

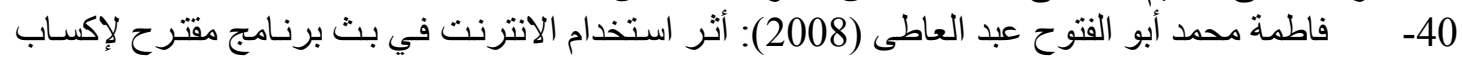

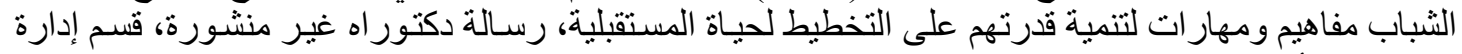

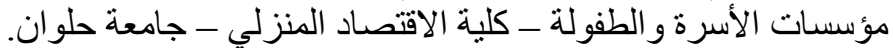

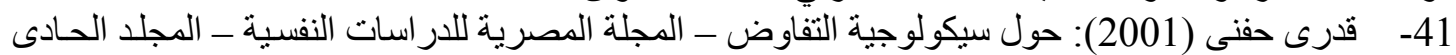
عشر - العدد 32 يوليو.

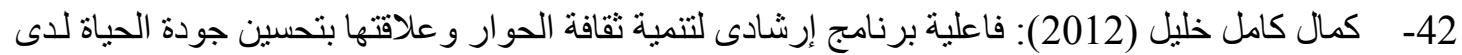

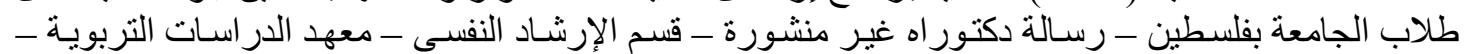
جامعة القاهرة.

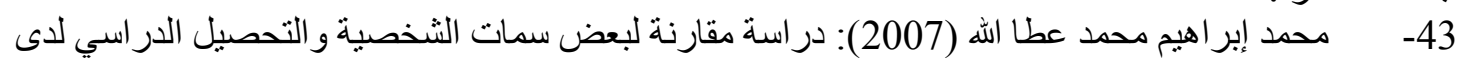

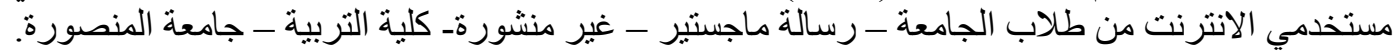

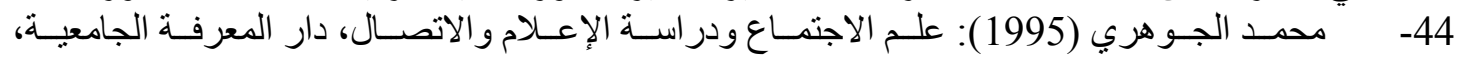
الإسكندرية.

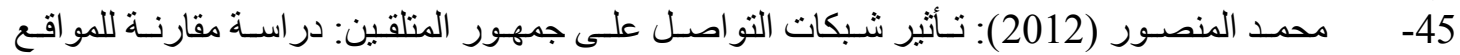

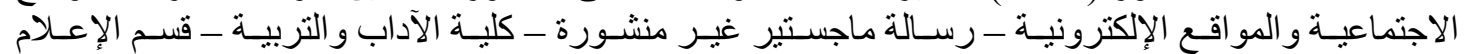
و الاتصال - الأكاديمية العربية في الدانمارك. 


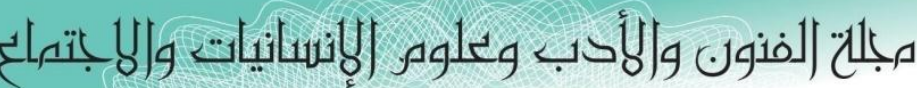

Journal of Arts, Literature, Humanities and Social Sciences

ISSN online: 2414 - 3383

ISSN print: 2616 - 3810

\section{العدد (42) أيلول - سبتمبر 2019}

46- محمد عبد الرازق إبر اهيم، هاني محمد يونس موسي (2011): القيم لدى شباب الجامعة في مصر ومتغير ات القرن الحادي و العشرين - مجلة كلية التربية - جامعة بانة بنها.

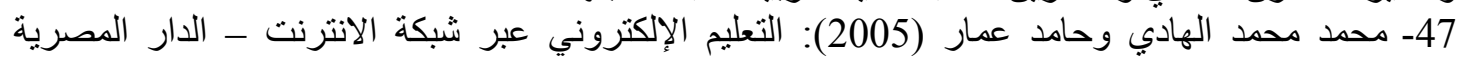
اللبنانية.

48- محمود القيعي (2008): ثقافة الحوار ـ الطبعة الأولى ـ القاهرة - مركز الحضارة العربية.

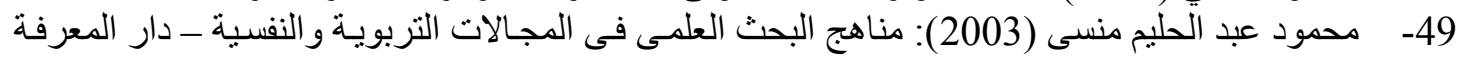

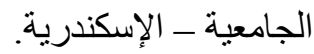

50- محمود عطا عقل (2003): النمو الإنساني (الطفولة و المر اهقة)، دار الخريجى للنشر و التوزيع.

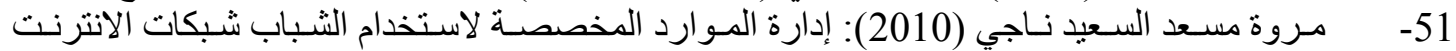

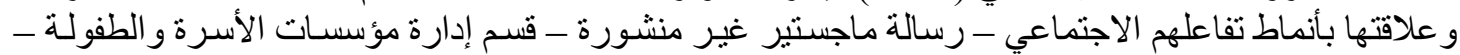
كلية الاقتصاد المنزلي - جامعة حلمَّوان.

52- مصطفي عبد السميع محمد (1999): تكنولوجيا التعليم - دراسـات عربيـة - مركز الكاتب للنشر -

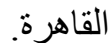
53- منال الحسن (2007):الحوار الأسريـ دار النهضة للنشر - ط1-القاهرة.

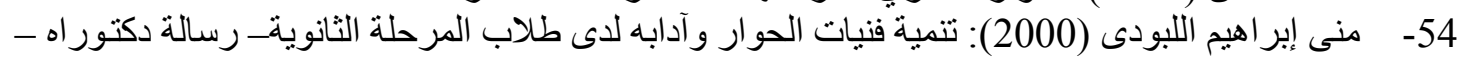
كلية التربية - جامعة إير عين شمس.

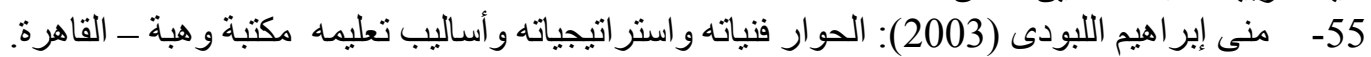

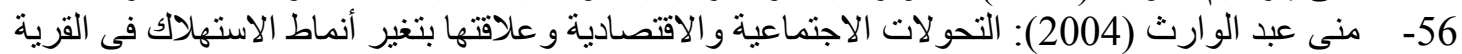

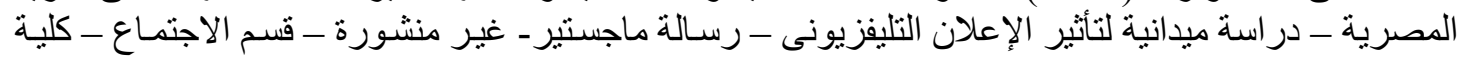
الآداب - جامعة المنوفية.

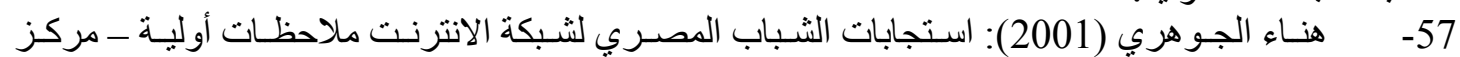

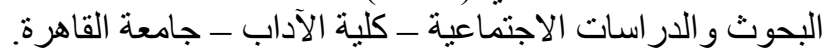

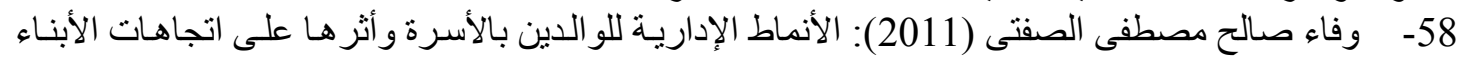

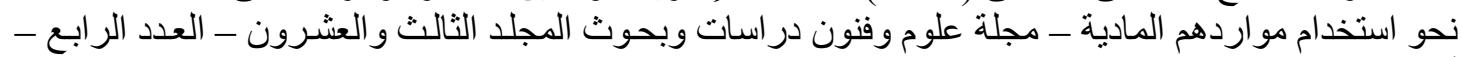

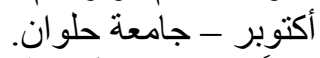
ثانياً: المراجع الأجنبية:

59- Bela H. Banth Patrick M. Jenlink (2005): Dialogue as a means of collective communication. New York. Kalwer Academic.

60- Danah M. Boyd, Nicole B. Ellison (2013): Social network sites, Definition, history and scholar ship. Journal of computer medicated communication. Vol. (13) issue (1).

61- Daved Smoloon (2009): The impact of the use of Facebook on the building society in the context of globalization. N.Y. Spectrum Publication.

62- Dwyer. Ton (2002): Imaginating- Power Social reproduction and computing: Uses of information technology by Brazilian Adolescents. International Sociological Association Brisbane. Australia.

63- Internet World State (2017): Usage and population statistics. Estimated Internet users for 2011 Mini Watts Marketing Group. Management. M.C. Grow Hill.

64- Patterson James I. (2002): Personality Style Consideration In Effective Dialogue. Journal \& Aggression. Vol 4. No. 1. 